Illinois State University

ISU ReD: Research and eData

Theses and Dissertations

$5-9-2019$

\title{
Chloride Signature And Transport In An Urban-Agricultural Watershed
}

Andrew Oberhelman

Illinois State University, ahoberh@ilstu.edu

Follow this and additional works at: https://ir.library.illinoisstate.edu/etd

Part of the Hydrology Commons

\section{Recommended Citation}

Oberhelman, Andrew, "Chloride Signature And Transport In An Urban-Agricultural Watershed" (2019). Theses and Dissertations. 1128.

https://ir.library.illinoisstate.edu/etd/1128

This Thesis is brought to you for free and open access by ISU ReD: Research and eData. It has been accepted for inclusion in Theses and Dissertations by an authorized administrator of ISU ReD: Research and eData. For more information, please contact ISUReD@ilstu.edu. 


\section{CHLORIDE SIGNATURE AND TRANSPORT IN AN URBAN-AGRICULTURAL}

WATERSHED

\section{Andrew Oberhelman}

80 pages

Manual and high-frequency observations $(\mathrm{n}=525)$ of chloride $\left(\mathrm{Cl}^{-}\right)$, bromide $\left(\mathrm{Br}^{-}\right)$, nitrate $\left(\mathrm{NO}_{3}-\mathrm{N}\right)$, sodium $\left(\mathrm{Na}^{+}\right)$, calcium $\left(\mathrm{Ca}^{2+}\right)$, and potassium $\left(\mathrm{K}^{+}\right)$in stream and tile-drain waters were conducted in an urban-agricultural watershed (10\% urban/impervious, $87 \%$ agriculture) to investigate the importance of stormflow to $\mathrm{Cl}^{-}$transport and to explore potential differences in the signature of $\mathrm{Cl}^{-}$originating from an urban source as compared to an agricultural source. The study was undertaken in Evergreen Lake Watershed (ELW) located in central Illinois. Samples were collected on a weekly interval from February 2018 to February 2019 at three station along Six Mile Creek (SMC), the main drainage of ELW. All storm events were sampled at high-frequency at the most downstream station while select storm events were sampled at an upstream station to compare how export changes along the stream. Mann-Whitney $\mathrm{U}$ test show ratios of $\mathrm{Cl}^{-}$to $\mathrm{Br}^{-}(\mathrm{p}$ $=0.045), \mathrm{NO}_{3}-\mathrm{N}(\mathrm{p}<0.0001), \mathrm{Ca}^{2+}(\mathrm{p}<0.0001)$, and $\mathrm{Na}^{+}(\mathrm{p}<0.0001)$ to be statistically significantly different between urban and agricultural waters. $\mathrm{Cl}^{-}$ratios indicate that road salt is the dominant source of $\mathrm{Cl}^{-}$in $\mathrm{ELW}$ while $\mathrm{KCl}$ fertilizer is a secondary source. Total $\mathrm{Cl}^{-}$export during the study period was $7.77 \times 10^{5} \mathrm{~kg}$. Storm events are vital to $\mathrm{Cl}^{-}$export in ELW, accounting for $57.5 \%$ of total $\mathrm{Cl}^{-}$load during only $19 \%$ of the study period. The importance of storm events varies seasonally with winter and spring storms accounting for nearly half of total $\mathrm{Cl}^{-}$export, while summer and fall storm event account for only $10 \%$ of total export. Results imply two periods of $\mathrm{Cl}^{-}$flushing in ELW. The first is associated with flushing of road salt from impervious surfaces 
following the cold season and second is associated with flushing salt build up after the dry season. When road salt is present on watershed surfaces increased discharge always corresponds with increased $\mathrm{Cl}^{-}$export. During storm events when road salt is not present on watershed surfaces increased in discharge corresponds with increased $\mathrm{Cl}^{-}$export for lower discharges $\left(\mathrm{Q}<4 \mathrm{~m}^{3} / \mathrm{s}\right)$. At higher discharges the relationship between discharge and $\mathrm{Cl}^{-}$export reaches an asymptote $(\sim 0.2$ $\mathrm{Kg} / \mathrm{s}$ ) where further increases in discharge do not correspond with increased $\mathrm{Cl}^{-}$export. Overall, urban, tile, and stream waters exhibit some degree of salinization in ELW with respect to $\mathrm{Cl}^{-}$as almost all sample concentrations were elevated above calculated background threshold concentration of $18 \mathrm{mg} / \mathrm{l}$. These results highlight the dramatic influence that deicing operations on only a small portion of a watershed can have on the $\mathrm{Cl}^{-}$dynamics of the entire system. Road salt appears to be able to salinize the dominantly agricultural ELW raising $\mathrm{Cl}^{-}$concentrations to levels hazardous to ecosystems and water supplies (>100 mg/l), although the exact extent of salinization in ELW remains unknown and is likely confined to surface and ground water in areas where deicing operations occur and that receive road salt runoff. Fertilizer inputs should also not be ignored as this work and others show that fertilizers have the potential to be an important contributor to salinization in northern regions that warrants further study. Due to the storage of $\mathrm{Cl}^{-}$in the subsurface, even small salt inputs in northern agricultural watersheds can induce salinization at a level that could take years to return to background and that could have far reaching ecologic and water quality impacts.

KEYWORDS: Road Salt, Chemical Ratios, Land Use, High Frequency Sampling, Tile Drain 


\section{CHLORIDE SIGNATURE AND TRANSPORT IN AN URBAN-AGRICULTURAL}

WATERSHED

ANDREW OBERHELMAN

A Thesis Submitted in Partial

Fulfillment of the Requirements

For the Degree of

MASTER OF SCIENCE

Department of Geography, Geology, and the Environment

ILLINOIS STATE UNIVERSITY

2019 
(C) 2019 Andrew Oberhelman 


\section{CHLORIDE SIGNATURE AND TRANSPORT IN AN URBAN-AGRICULTURAL WATERSHED}

ANDREW OBERHELMAN

COMMITTEE MEMBERS:

Eric W. Peterson, Chair

Catherine M. O’Reilly

Walton R. Kelly 


\section{ACKNOWLEDGMENTS}

I would like to thank my committee chair, Dr. Eric Peterson, for his continuous support and guidance during the course of this work. I would also like to thank my other committee members Dr. Catherine O’Reilly and Dr. Walton Kelly for their advice and feedback. This work was funded by the Illinois Groundwater Association and Illinois State University. Special thanks to the City of Bloomington, McLean County, and Rick Twait for the usage of equipment, advice, and assistance with field work. Analysis of samples would not have been possible without the help of Tony Ludwig from the Illinois State Department of Chemistry. Thanks to Kathy Alt for permission to sample and gauge Six Mile Creek on her land.

A. O. 


\section{CONTENTS}

Page

$\begin{array}{ll}\text { ACKNOWLEDGMENTS } & \text { i }\end{array}$

$\begin{array}{ll}\text { CONTENTS } & \text { ii }\end{array}$

TABLES $\quad$ iv

FIGURES

CHAPTER I: INTRODUCTION 1

Road Salt and Freshwater Salinization $\quad 1$

Objectives, Questions, and Hypotheses $\quad 5$

$\begin{array}{ll}\text { CHAPTER II: METHODS } & 7\end{array}$

$\begin{array}{ll}\text { Study Area } & 7\end{array}$

$\begin{array}{lr}\text { Fertilizer Use } & 9\end{array}$

$\begin{array}{ll}\text { Field Methods } & 10\end{array}$

$\begin{array}{ll}\text { Weekly Sampling } & 10\end{array}$

$\begin{array}{ll}\text { Storm Event Sampling } & 11\end{array}$

Tile Drain Sampling $\quad 11$

$\begin{array}{ll}\text { Groundwater Chemistry } & 12\end{array}$

$\begin{array}{ll}\text { Data Collection } & 12\end{array}$

$\begin{array}{ll}\text { Sample Analysis } & 12\end{array}$

$\begin{array}{ll}\text { High-Frequency Data } & 13\end{array}$

$\begin{array}{ll}\text { Data Analysis } & 13\end{array}$

$\begin{array}{ll}\text { Seasons and Storm Events } & 13\end{array}$

Discharge and Load 14 
$\begin{array}{ll}\text { Background Concentrations } & 18\end{array}$

Box Plots, Timeseries, and Chemical Ratios $\quad 18$

$\begin{array}{ll}\text { CHAPTER III: RESULTS } & 19\end{array}$

$\begin{array}{ll}\text { Overview } & 19\end{array}$

Water Chemistry and Chloride Ratios 24

$\begin{array}{ll}\text { Anions } & 24\end{array}$

$\begin{array}{ll}\text { Cations } & 28\end{array}$

Chloride Ratios and Ratio Plots 33

$\begin{array}{ll}\text { Chloride Transport } & 41\end{array}$

Storm Events and Total $\mathrm{Cl}^{-}$Export $\quad 41$

$\begin{array}{ll}\text { Seasonal Load } & 44\end{array}$

$\begin{array}{ll}\text { CHAPTER IV: DISCUSSION } & 47\end{array}$

$\begin{array}{ll}\text { Overview } & 47\end{array}$

Water Chemistry and Chloride Source $\quad 47$

Impact of Storm Events on Chloride Load and Concentration 55

CHAPTER V: CONCLUSIONS

$\begin{array}{lc}\text { REFERENCES } & 61\end{array}$

APPENDIX A: WEEKLY FIELD AND MAJOR ION DATA 68

APPENDIX B: EVENT SAMPLE MAJOR ION DATA 74 


\section{TABLES}

Tables

Page

1. Maximum, minimum, and median values for select ions in $\mathrm{mg} / \mathrm{l}$

2. WS2 and tile-drain water molar $\mathrm{Cl}^{-}$ratio Mann-Whitney $\mathrm{U}$ test results 36 


\section{FIGURES}

Figure

Page

1. Map of Evergreen Lake Watershed 8

2. Rating curves for Six Mile Creek at WS1 and WS1.5 16

3. (A) Daily precipitation, (B) calculated discharge at WS1, and (C) 17 calculated discharge WS1.5 during the study period

4. Cumulative probability plots for (A) $\mathrm{NO}_{3}-\mathrm{N},(\mathrm{B}) \mathrm{Cl}^{-},(\mathrm{C}) \mathrm{Na}^{+}$, and (D)

$\mathrm{K}^{+}$with background threshold concentration labeled

5. Boxplots for $\mathrm{NO}_{3}-\mathrm{N}, \mathrm{Cl}^{-}$, and $\mathrm{Br}^{-}$using data from all samples grouped by location or type (tile or well)

6. $\mathrm{Cl}^{-}$concentrations

7. $\mathrm{NO}_{3}-\mathrm{N}$ concentrations

8. Boxplots for $\mathrm{Ca}^{2+}, \mathrm{Na}^{+}$, and $\mathrm{K}^{+}$using data from all samples grouped by location or type

9. $\mathrm{K}^{+}$concentrations

10. $\mathrm{Na}^{+}$concentrations

11. $\mathrm{Ca}^{2+}$ concentrations

12. $\mathrm{Na}^{+}$vs. $\mathrm{Cl}^{-}$with $1: 1$ line in red

13. $\mathrm{Cl}^{-}$vs. $\mathrm{NO}_{3}-\mathrm{N}$ with samples grouped by (A) sample location/type and (2) season

14. $\mathrm{Cl}^{-} / \mathrm{Br}^{-}$ratio vs. $\mathrm{Cl}^{-}$concentration of all samples with measurable $\mathrm{Br}^{-}$

15. $\mathrm{K}^{+}$vs. $\mathrm{Cl}^{-}$with $1: 1$ in in red 
16. $\mathrm{Ca}^{2+}$ vs. $\mathrm{Cl}^{-}$with 2:1 line in red

17. (A) Cumulative $\mathrm{Cl}^{-}$load by season and seasonal storm events during the calculation period at WS1 (TCL - Total cumulative load, SCL - Total storm cumulative load, PoTCL - Percent of total cumulative load, PoSCL - Percent of total storm cumulative load)

18. Cumulative load (solid line) and hydrograph (dotted line) at WS1 for the calculation period

19. Cumulative load (solid line) and discharge (dotted line) for a spring storm at WS1 and WS1.5

20. Plot of instantaneous $\mathrm{Cl}^{-}$flux vs. discharge at WS1 with data sorted by season

21. Combination Cl- concentration (dashed red) and hydrograph (black) at WS1 


\section{CHAPTER I: INTRODUCTION}

\section{Road Salt and Freshwater Salinization}

Natural salinity in freshwaters originates from rock weathering, sea spray, and rainfall. Anthropogenic activities such as irrigation, resource extraction, wastewater treatment, land clearing, industry, and road deicing have greatly increased the salt concentration in freshwaters around the world (Schulz and Cañedo-Argüelles, 2018; Dugan et al., 2017; Cañedo-Argüelles et al., 2016; Gutchess et al., 2016; Kaushal et al., 2005). Increased freshwater salinity is a growing environmental problem linked to biological degradation, reduced ecosystem functioning, and threatens water resource security (Schulz and Cañedo-Argüelles, 2018; Cañedo-Argüelles et al., 2016; Cañedo-Argüelles et al., 2013).

Salinization in northern regions, represented by increased chloride $\left(\mathrm{Cl}^{-}\right)$concentrations, is associated with a dramatic increase in the use of deicing salts since 1940 (Ledford et al., 2016; Jackson and Jobbágy, 2005; Kaushal et al., 2005). The most common deicing salt is sodium chloride, but magnesium and calcium chloride are used when the freeze point of water needs to be depressed below $-18{ }^{\circ} \mathrm{C}$. The United States alone applied 24.5 million megagrams of rock salt for driver safety in 2014, accounting for $45 \%$ of total salt consumed in the U.S. that year (Lilek, 2017). While deicing salts are vital to driver safety in freezing conditions, elevated $\mathrm{Cl}^{-}$concentrations can damage ecosystems, infrastructure, and drinking water supplies (Rivett et al., 2016; Kushal et al., 2005).

$\mathrm{Cl}^{-}$is a conservative and highly mobile ion that is not easily removed from aquatic systems. Its harmful impacts at elevated levels are well documented (Wyman and Koretsky, 2018; Prosser et al., 2017; Cañedo-Argüelles et al., 2013; Nelson et al., 2009; Kushal et al., 2005). These include invasion of saltwater species into previously freshwater ecosystems, altered lake chemistry and 
mixing, stream acidification, altered mortality and reproduction of aquatic plants and animals, and altered wetland communities (Kushal et al., 2005). Even at relatively low concentrations ( 100 $\mathrm{mg} / \mathrm{l}) \mathrm{Cl}^{-}$can alter microbial communities and inhibit denitrification (Kushal et al., 2005). Seasonal $\mathrm{Cl}^{-}$fluctuations related to deicing also harm freshwater aquatic life because they cannot adjust to the resultant changes in osmotic potential (Cañedo-Argüelles et al., 2013; Kushal et al., 2005).

Another impact of deicing salts is the degradation of water supply quality (Stets et al., 2017). The U.S. Environmental Protection Agency (EPA) has set the acute and chronic water quality limits for $\mathrm{Cl}^{-}$of $860 \mathrm{mg} / \mathrm{l}$ and $230 \mathrm{mg} / \mathrm{l}$, respectively (Ledford et al., 2016, USEPA 2011). $\mathrm{Cl}^{-}$rich waters have also been shown to leach lead from pipes and mobilize soil bound heavy metals such as cadmium, lead, and copper (Nelson et al., 2009; Edwards and Triantafyllidou, 2007). A salty taste is imparted above the EPA secondary maximum contaminant limit of $250 \mathrm{mg} / \mathrm{l}$ $\mathrm{Cl}^{-}$and waters may become harmful to human health at higher $\mathrm{Cl}^{-}$concentrations due to toxic impurities in deicing salts (USEPA, 2011; Kushal et al., 2005).

Cations associated with deicing salts, particularly sodium $\left(\mathrm{Na}^{+}\right)$, also have the potential to harm human health, aquatic ecosystems, and soils (Kushal et al., 2005; Norrström and Bergstedt, 2001). Concentrations of $\mathrm{Na}^{+}$above $20 \mathrm{mg} / \mathrm{l}$ have been labeled harmful by the EPA to individuals suffering from hypertension. Even small fluctuations in the concentration of $\mathrm{Na}^{+}$(7-14 mg/l) can cause harmful osmoregulatory stress in detritivores, which could alter stream processes. (Tyree et al., 2017). Elevated $\mathrm{Na}^{+}$in soils results in a loss of permeability and can cause significant damage to soil structure (Norrström and Bergstedt, 2001).

The magnitude of salinization in northern regions has a strong relationship with land use, with urban land use associated with the largest post-1940 increase in $\mathrm{Cl}^{-}$concentrations (Dugan et al., 2017; Lax et al., 2017; Kushal et al., 2005; Herlihy et al., 1998). Overland flow and infiltration 
during precipitation and melt events is the primary transport mechanism for deicing salt to move to streams and into the subsurface (Ledford et al., 2016; Rivett et al., 2016; Cañedo-Argüelles et al., 2013). Elevated baseflow salinity is attributed to storage of road salt derived $\mathrm{Cl}^{-}$in groundwater (Cañedo-Argüelles et al., 2013; Kelly et al., 2008; Kushal et al., 2005). Wind and spray from vehicle tires also play a role in the movement of salt off roads and into freshwater systems (Cañedo-Argüelles et al., 2013). Compounds used in water softeners, septic systems, and to treat wastewater are other sources of $\mathrm{Cl}^{-}$in urban areas that have been shown to contribute to salinization (Hubbart et al., 2017; Lax et al., 2017; Kelly et al., 2010).

Even small increases in the amount of impervious surface cover have resulted in salinization (Dugan et al., 2017; Kushal et al., 2005). A recent study found that urban or rural lakes surrounded by $>1 \%$ impervious surface cover exhibit increasing $\mathrm{Cl}^{-}$trends (Dugan et al., 2017). However, to a lesser degree, agricultural land use is also associated with elevated $\mathrm{Cl}^{-}$concentrations (Hubbart et al., 2017; Lax et al., 2017; Ludwikowski, 2016). The relationship between land use and salinization is thus complicated in urban-agricultural watersheds. While urban $\mathrm{Cl}^{-}$sources are dominant, agricultural $\mathrm{Cl}^{-}$has the potential to contribute to unanticipated levels of salinization in rural and urban-rural watersheds.

The threat posed by salinization to aquatic ecosystems and drinking water supplies make the study of $\mathrm{Cl}^{-}$dynamics imperative. While many studies have explored the residence time of $\mathrm{Cl}^{-}$at stream and basin scales, few have explored $\mathrm{Cl}^{-}$export dynamics at high resolution in salt impacted streams (Hubbart et al., 2017; Ludwikowski, 2016; Gutchess et al., 2016; Rivett et al., 2016; Kelly et al., 2008). High intensity sampling of base and storm flows is needed to shed light on the dynamics of acute and chronic $\mathrm{Cl}^{-}$concentrations as well as the role of storms in flushing salt from the subsurface. Understanding these dynamics is essential in evaluating the risk of 
salinization to specific aquatic ecosystems and water supplies. Thus, studies that explore the importance of storm events to $\mathrm{Cl}^{-}$transport dynamics are warranted.

Furthermore, it is not clear why salinization has been seen in rural watersheds where the impacts of urbanization are minimal and impervious surface cover is low (Lax and Peterson, 2009, Kushal et al., 2005). A portion can be attributed to road salts, but few studies have explored the potential of agricultural $\mathrm{Cl}^{-}$sources to contribute to salinization. The primary agricultural sources of $\mathrm{Cl}^{-}$are livestock waste and the use of $\mathrm{KCl}$ as a potassium fertilizer (David et al., 2016; Kelly et al., 2010; Panno et al., 2006a; Böhlke 2002). Nitrification inhibitors represent another potential agricultural source of $\mathrm{Cl}^{-}$. Nitrapyrin (2-Chloro-6-(trichloromethyl)pyridine, $\mathrm{C}_{6} \mathrm{H}_{3} \mathrm{Cl}_{4} \mathrm{~N}$ ) is a common nitrification inhibitor applied to fields with anhydrous ammonia fertilizer after harvest to inhibit ammonia oxidation thereby preserving the fertilizer for crop uptake (Redemann et al., 1964). Nitrapyrin in the soil degrades into 6-chloro-picolinic acid $\left(\mathrm{C}_{6} \mathrm{H}_{4} \mathrm{ClNO}_{2}\right)$, which is thought to break down through microbial action or plant uptake during which a portion is dehalogenated (Meikle and Redemann, 1966; Redemann et al., 1964). When this biota breaks down, mobile $\mathrm{Cl}^{-}$may be released into the soil and shallow groundwater (Meikle and Redemann, 1964). 


\section{Objectives, Questions, and Hypotheses}

Salinization of freshwater represents a significant threat to infrastructure, aquatic ecosystems, and water supplies in northern regions. It is important to further understand stream and basin scale $\mathrm{Cl}^{-}$dynamics to address the problems posed by salinization. Along with sources related to roads and urban centers, agricultural $\mathrm{Cl}^{-}$sources are poorly understood and could represent a significant contribution to rising background $\mathrm{Cl}^{-}$levels. This project aims to:

1. Differentiate the signature of urban and agricultural $\mathrm{Cl}^{-}$with chemical ratios in an urbanagricultural watershed.

(a) Urban and Agricultural $\mathrm{Cl}^{-}$signature

$\mathrm{H}_{0}$ : Waters from Urban and Agricultural sources have the same $\left[\mathrm{Cl}^{-}\right]:[\mathrm{X}]$ ratios (where $\mathrm{X}$ is $\mathrm{Ca}^{2+}$, $\mathrm{K}^{+}, \mathrm{NO}_{3}-\mathrm{N}, \mathrm{Na}^{+}$, or $\left.\mathrm{Br}^{-}\right)$

$\mathrm{H}_{\mathrm{a}}$ : Urban and Agriculture sources have different $\left[\mathrm{Cl}^{-}\right]:[\mathrm{X}]$ ratios

\section{(b) $\mathrm{Cl}^{-}$source identification}

Can chloride sources be differentiated?

- Sources of $\mathrm{Cl}^{-}$in an urban-agricultural watershed can be identified using relationships established in previous studies between $\mathrm{Cl}^{-}$ratios $\left(\mathrm{NO}_{3}-\mathrm{N}\right.$ and $\left.\mathrm{Br}^{-}\right)$and $\mathrm{Cl}^{-}$sources (Angel and Peterson, 2015; Panno et al., 2006a; Böhkle, 2002) along with $\mathrm{Cl}^{-}$ratios $\left(\mathrm{Na}^{+}, \mathrm{Ca}^{2+}\right.$, and $\left.\mathrm{K}^{+}\right)$expected in waters impacted by deicing salts or potassium fertilizer. If the signature of road salt is observed in an urban-agricultural watershed then it is likely to be a major $\mathrm{Cl}^{-}$source, even if the percentage urban land use is low (Dugan et al., 2017; Kushal et al., 2005). 
2. Investigate the contribution of storm events to $\mathrm{Cl}^{-}$export in an urban-agricultural watershed.

(a) Storm events and total $\mathrm{Cl}^{-}$export

Do storm events make a greater contribution to $\mathrm{Cl}^{-}$export than non-event periods?

- Storm events will make a greater contribution to $\mathrm{Cl}^{-}$export due their role in the flushing of watershed surfaces and increasing baseflow to watershed drainages.

\section{(b) Seasonal $\mathrm{Cl}^{-}$export}

Does the contribution of storm events to $\mathrm{Cl}^{-}$export differ among the seasons?

- Storm events will make larger contributions to $\mathrm{Cl}^{-}$export during the cold season if road salt was applied because road salt is primarily a seasonal $\mathrm{Cl}^{-}$source and will outweigh the more constant $\mathrm{Cl}^{-}$contributions from sources such as wastewater treatment and agriculture. Otherwise variation in seasonal storm event $\mathrm{Cl}^{-}$export will be controlled by the number of storms during each season as volume of discharge will be the dominant factor influencing the amount of $\mathrm{Cl}^{-}$export. 


\section{CHAPTER II: METHODS}

\section{Study Area}

The Evergreen Lake watershed (ELW), contained within the greater Mackinaw River Basin, encompasses $106.4 \mathrm{~km}^{2}$ in central Illinois and is part of both McLean and Woodford Counties (Fig. 1). The ELW is situated in a 46 to 137 meter thick end moraine and till deposits of the Wisconsinan glaciation. (ISGS Staff, 2005; McLean et al., 1997). Agriculture, primarily rotation between corn and soybean row crop, and rural grassland represent the dominant land use (>87\%) in the watershed (Evergreen Lake Watershed Planning Committee, 2006). Urban land and paved roads made up 8\% of total ELW acreage in 2000 (Evergreen Lake Watershed Planning Committee, 2006). However, commercial and residential developments along Interstate 39, the northern edge of Normal, and southern edge of Hudson have increased urban land use in ELW by approximately $2 \%$ between 2000 and 2019. The Village of Hudson and the northern edge of the town of Normal are the main urban centers of the watershed (Fig. 1). Major roads include Interstates 39 and 55, which respectively run north-south through the middle of the watershed and along its southeastern edge (Fig. 1). There are approximately 750 licensed septic systems in ELW that serve residences and organizations outside of the Town of Normal (Evergreen Lake Watershed Planning Committee, 2006).

ELW has a temperate climate. Winter and summer have average temperatures of $2.2{ }^{\circ} \mathrm{C}$ and $19.4^{\circ} \mathrm{C}$, respectively. Average annual rainfall is $96.5 \mathrm{~cm}$ with the majority $(61 \%)$ falling in April through September. Yearly snowfall averages $51 \mathrm{~cm}$. Potential major sources of $\mathrm{Cl}^{-}$rich road runoff are the Village of Hudson, the northern edge of Normal, and the two interstates (Fig. 1). $\mathrm{NaCl}$ sprayed with a $32 \%$ calcium chloride solution is the primary deicing agent used in Mclean County (Jerry Stokes, McLean County Engineer, personal communication, 2018). 
Six Mile Creek (SMC) is the largest of three major tributaries (two remain unnamed) for Evergreen Lake, one of two reservoirs serving as the source of water for the City of Bloomington (Evergreen Lake Watershed Planning Committee, 2006). The lake was created by damming SMC in 1971. The headwaters of SMC are rooted in the northern outskirts of the town of Normal. SMC flows $18.0 \mathrm{~km}$ from southeast to northwest crossing Interstate 39 and paralleling it along the western edge of Hudson before draining into Evergreen Lake (Fig. 1). It is estimated that tile drains are used to drain about 7500 acres ( 25\%) in ELW, and, as a result, tile discharge is assumed to make a large contribution to flow in SMC (Evergreen Lake Watershed Planning Committee, 2006).

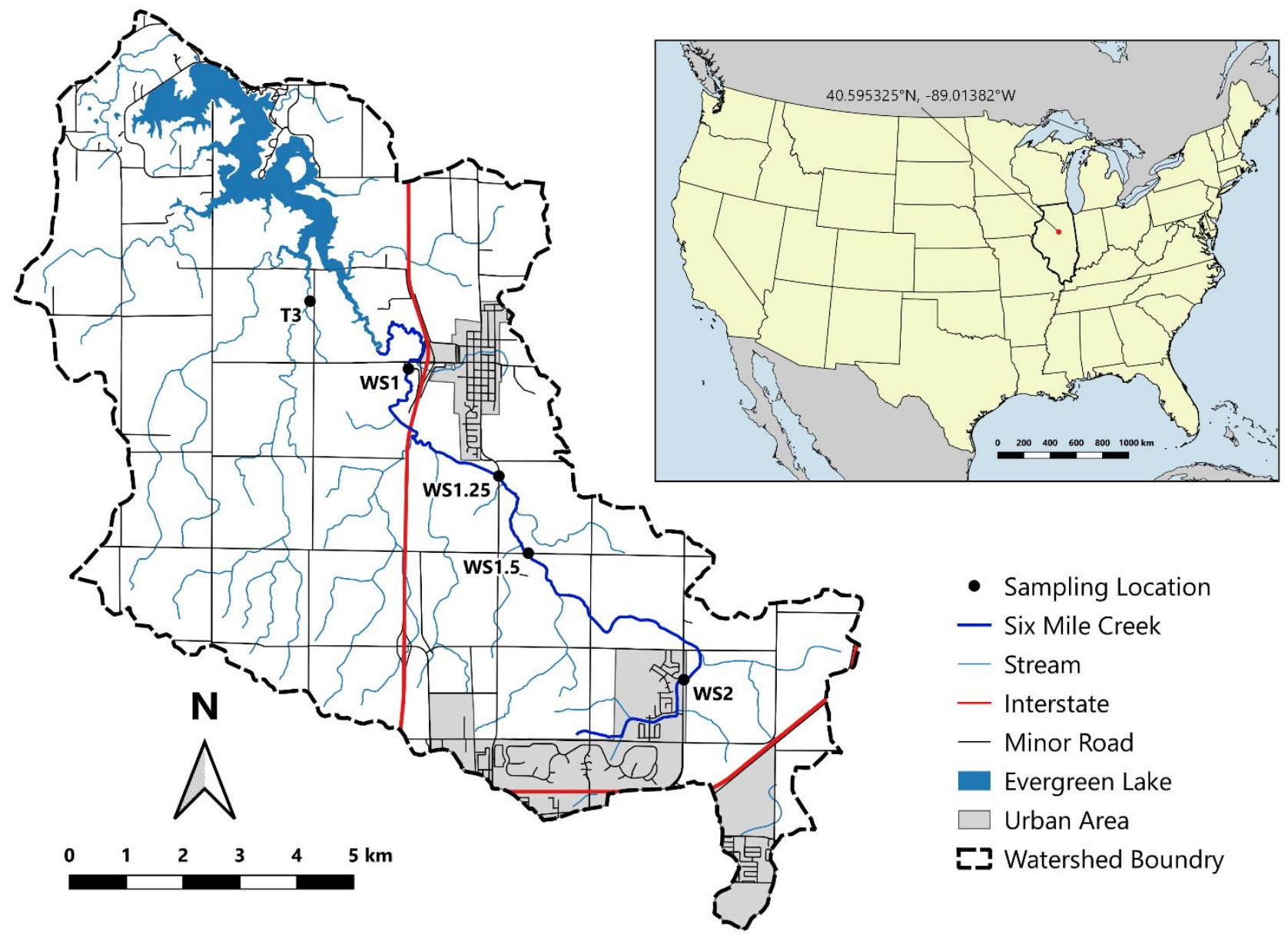

Figure 1. Map of Evergreen Lake Watershed. 


\section{Fertilizer Use}

Nitrogen $(\mathrm{N})$ and Phosphorus $(\mathrm{P})$ are the main nutrients added to fields in ELW (Michael Ruffatti, personal communication, 2019). $\mathrm{N}$ is applied in the form of anhydrous ammonia or urea ammonium nitrate (Ruffatti, 2019). $\mathrm{P}$ is applied in the form of diammonium phosphate, which also supplies a small amount of N (Ruffatti, 2019). Timing of fertilizer application in the ELW depends on if a field is in corn-corn or corn-soybean rotation (Ruffatti, 2019). $\mathrm{N}$ application by farmers in a corn-corn rotation is $27 \%$ applied in the fall and $73 \%$ applied in the spring (Ruffatti, 2019). Application for corn-soybean rotation is a more equal split with $45 \%$ of farmers applying $\mathrm{N}$ in the fall and 55\% applying $\mathrm{N}$ in the spring (Ruffatti, 2019). In recent years (2014-2016), farmers in ELW ( 2/3) have moved toward supplying $\mathrm{N}$ in multiple applications over the growing season (Ruffatti, 2019).

Fields in ELW are also likely fertilized with $\mathrm{K}^{+}$. The dominant form of $\mathrm{K}^{+}$applied to fields in Illinois is $\mathrm{KCl}$ (David et al., 2016; Kelly et al., 2010; Panno et al., 2006a). Information on the use of $\mathrm{KCl}$ is less available, and the application schedule likely varies between farmers based on soil needs and crop type. In 2008 the U.S. Department of Agriculture (USDA) reported that about $80 \%$ of corn fields and $30 \%$ of soybean fields in Illinois received annual $\mathrm{KCl}$ treatment (Kelly et al., 2010). Corn and soybean planted acreage in McLean county in 2018 was 314,500 and 312,000 respectively (USDA, 2018). Panno et al. (2006b) stated based on a 2001 personal communication, that approximately $90 \%$ of Illinois farmers apply $\mathrm{KCl}$ and that the $\mathrm{KCl}$ application rate for Illinois cropland was about $90 \mathrm{Kg} / \mathrm{acre}$ every 2 years. David et al. (2016) reported application of KCl every 3 to 4 years on fields owned by the University of Illinois over the course of their study. 


\section{Field Methods}

\section{Weekly Sampling}

Grab samples were collected at three stream stations each week between February 16, 2018 and February 17, 2019 (Fig. 1). WS1 was chosen as the furthest downstream station because instrumentation was already in place and because it is located downstream where SMC crosses the Interstate 39 and passes by the town of Hudson. WS2, the most upstream station is located at the discharge point of a stormwater retention pond receiving drainage from two subdivisions and a golf course on the northern edge of Normal. It was chosen to capture the signature of urban input to SMC. WS1.5 and WS1.25 were chosen as intermediate stations between WS1 and WS2 where flow would be continuous with WS1 to illustrate how water evolved with more agricultural input from tile drains. WS1.5 was only sampled until June 1, 2018, when permission to sample at the site was withdrawn by the landowner. Sampling was shifted $1.6 \mathrm{~km}$ downstream to WS1.25 for the remainder of the study. Overland flow between WS2 and the intermediate sampling sites was only continuous during high flow events because of dry conditions or complete infiltration of flow along a $3.5 \mathrm{Km}$ stretch of SMC 1/2 Km downstream of WS2 (Fig. 1).

Grab samples were drawn directly from the stream using a $60 \mathrm{ml}$ syringe triple rinsed with stream water and passed through a $1.0 \mu \mathrm{m}$ Pall type A/E $25 \mathrm{~mm}$ glass fiber syringe filter (syringe filter) into an acid washed Nalgene polypropylene $30 \mathrm{ml}$ sample bottle (30 $\mathrm{ml}$ sample bottle). Samples were frozen on return to the Illinois State University (ISU) lab due to limited refrigerator space. Discharge, water level, temperature, $\mathrm{pH}$, dissolved oxygen, and specific conductivity were measured at each location during weekly samplings. Discharge $\left(\mathrm{m}^{3} / \mathrm{s}\right)$ was measured with a Stontek Flowtracker acoustic doppler velocimeter following the midsection method using velocity measured at the 0.6-depth. In this method, stream discharge is measured by taking the sum of discharges estimated for at least 15 stream segments, where the mean water velocity at a point 
along the stream section, taken to be that measured at 0.6 of the depth below the water surface, is multiplied by the area for a stream segment defined as the depth at the current measurement point multiplied by the sum of half the distances from the current measurement point to the preceding and next measurement points. A YSI Sonde was used to measure temperature $\left({ }^{\circ} \mathrm{C}\right), \mathrm{pH}$, dissolved oxygen $(\mathrm{mg} / \mathrm{l})$, and specific conductance $(\mu \mathrm{S} / \mathrm{cm})$. A weighted measuring tape was used to measure the water level (m) from a fixed reference point at each site.

\section{Storm Event Sampling}

Two 24 bottle ISCO auto samplers were used to sample storm events. One ISCO was permanently in place at WS1 and was triggered when stream turbidity measured by a DTS-12 digital turbidity sensor rose above or fell below certain threshold values (Lampo, 2017). Select storm events at WS1.5 or WS1.25 were sampled with the second transportable ISCO auto sampler that was set to collect a sample every $2,2.5,3$, or 3.5 hours depending on forecasted weather. All storms were sampled at WS1 until January 25, 2019 when in-stream instrumentation had to be removed for maintenance and due to freezing weather conditions. Storm samples were manually selected for processing to achieve a representative set along an event hydrograph. Samples selected for processing were filtered through a syringe filter into an acid washed $30 \mathrm{ml}$ sample bottle and then frozen. ISCO bottles were acid washed with $1.5 \% \mathrm{H}_{2} \mathrm{SO}_{4}$ between use. Storm events were not sampled at WS2.

\section{Tile Drain Sampling}

Tile drains were located near each stream station except WS1.5 and were sampled on rotation each week. These tile drains were located within $50 \mathrm{~m}$ of respective weekly sampling sites. Samples were drawn directly from the drain if flowing using a $60 \mathrm{ml}$ syringe triple rinsed with tile 
water and passed through a syringe filter into an acid washed $30 \mathrm{ml}$ sample bottle and frozen on return to the lab. Discharge $\left(\mathrm{m}^{3} / \mathrm{s}\right)$ was measured for stream station tile drains using a bucket marked with a known volume and a stopwatch. Tile-drain water samples from the adjacent Lake Bloomington watershed were used to supplement tile water samples collected in ELW as this watershed has similar land use to ELW allowed for a tile-drain water sample set with greater temporal coverage without a large increase in the amount of field work. The tile these samples were drawn from will be referred to as T1. Samples were collected at T1 with an in place 24 bottle ISCO auto sampler that collects samples based on flow volume through the drain. T1 samples were filtered in the lab through a syringe filter into an acid washed $30 \mathrm{ml}$ sample bottle and then frozen. Five tile-drain water samples from a separate study sampling a drain located at T3 (Fig. 1) were also analyzed in order to characterize a tile located away from major roads or urban areas in ELW.

\section{Groundwater Chemistry}

Five samples from a shallow well ( $<5$ meters) installed in the T3 riparian buffer zone (Fig. 1) were selected for analysis to assess the major ion composition of non-tile drain shallow groundwater in ELW. These samples were filtered in the lab through a syringe filter into an acid washed $30 \mathrm{ml}$ sample bottle and then frozen.

\section{Data Collection}

Sample Analysis

Weekly grab and storm samples were analy

zed for major ion concentrations $\left(\mathrm{Na}^{+}, \mathrm{Ca}^{2+}, \mathrm{K}^{+}, \mathrm{Mg}^{2+}, \mathrm{Cl}^{-}, \mathrm{Br}^{-}, \mathrm{NO}_{3}-\mathrm{N}, \mathrm{PO}_{4}-\mathrm{P}, \mathrm{SO}_{4}^{2-}\right)$ at ISU. Anions concentrations were measured on a Dionex ICS-1100 Ion Chromatograph. Cation concentrations were measured on a PerkinElmer Optima 8300 Inductively Coupled Plasma Optical Emission Spectrometer. WS1 storm samples and T1 samples were acidified to $\mathrm{pH}<2$ with $50 \%$ 
$\mathrm{H}_{2} \mathrm{SO}_{4}$ at the time of collection because they were originally collected as part of a different study that followed this procedure. Weekly and WS1.25 and WS1.5 event samples were not acidified in order to be able to measure $\mathrm{SO}_{4}{ }^{2-}$ concentrations. All samples were acidified with $50 \% \mathrm{H}_{2} \mathrm{SO}_{4}$ to a $\mathrm{pH}<2$ before cation analysis to reduce sorption to the walls of sample bottles. Anion standards were made from salts at ISU, while cation standards were made by diluting a purchased stock solution. Data quality assurance and quality control procedures consisted of a series of matrix spikes, sample duplicates, independent standard calibration verification, and sample blanks.

Weekly chemical and field data can be found in Appendix A. Storm event sample chemical data can be found in Appendix B.

\section{High-Frequency Data}

High-frequency data were collected at all stream stations. Rainfall (mm), conductivity $(\mathrm{mS} / \mathrm{cm})$, temperature $\left({ }^{\circ} \mathrm{C}\right)$ and stage $(\mathrm{m})$ were measured at WS1 using an RG-T Precision Tipping Bucket Rain Gauge, a Meter Environment Conductivity-Temperature-Depth sensor (CTD), and an SDI pressure transducer, respectively. At WS1, all data were recorded on an Axiom $\mathrm{H} 2$ data logger except for conductivity, which was recorded separately by the CTD. Conductivity data at WS1 are incomplete due to sensor malfunction. Stage and temperature were logged on an Onset MX2001-04 level logger and sensor set at WS1.5 and WS1.25. Stage, temperature, and conductivity were logged using a CTD at WS2. Data were logged on a 15-minute interval by all instruments except CTDs, which logged on a 5-minute interval.

\section{Data Analysis}

Seasons and Storm Events

The northern hemisphere meteorological definition of the seasons is used in this study: winter is December 1 to February 28, spring is March 1 to May 31, summer is June 1 to August 
31, and fall is September 1 to November 30. Strom events were defined as a precipitation event that caused discharge to increase and triggered the ISCO auto sampler at WS1. The beginning and end of storm events were chosen manually after inspection of event hydrographs.

\section{Discharge and Load}

High-frequency stage, weekly discharge measurements, and chemical data were used to assess the importance of storm events to $\mathrm{Cl}^{-}$export in SMC. The stage-discharge relationship built from weekly discharge measurements (Fig. 2) was used to create a hydrograph (Fig. 3) for each station that was paired with a 15 -minute timeseries of $\mathrm{Cl}^{-}$concentration built from samples collected at that station. Timeseries were constructed by assuming the $\mathrm{Cl}^{-}$concentration measured in a sample collected at a known time represents the $\mathrm{Cl}^{-}$concentration in the stream for all time steps until the next step where a water sample was collected and analyzed. Load was then estimated along a 15-minute interval by multiplying $\mathrm{Cl}^{-}$concentration by the calculated discharge (eq. 1).

$$
\text { Load }\left(\frac{\mathrm{kg}}{\mathrm{s}}\right)=\text { Concentration }\left(\frac{\mathrm{mg}}{\mathrm{l}}\right) \times \text { Discharge }\left(\frac{\mathrm{m}^{3}}{\mathrm{~s}}\right) \times \frac{1}{10^{6}}\left(\frac{\mathrm{kg}}{\mathrm{mg}}\right) \times 10^{3}\left(\frac{\mathrm{l}}{\mathrm{m}^{3}}\right) \text { eq.1 }
$$

Cumulative $\mathrm{Cl}^{-}$loads were determined by multiplying the average of two subsequent load estimates by the time difference between the two, then taking the summation for the entire calculation interval (eq. 2). Load calculations were only performed at WS1 and WS1.5 as a reliable discharge stage relationship was unable to be established at WS2 and WS1.25. Further, loads were only calculated for the majority of the study period at WS1, while at WS1.5 loads were calculated for only two storm events that had good sample coverage (Fig. 3B and 3C). Loads at WS1 were not calculated after January 25, 2019 as sample and stage data coverage was insufficient due to the removal of instrumentation. 


$$
\text { Cumulative Load }(\mathrm{kg})=\sum_{\mathrm{i}=1}^{\mathrm{n}}\left(\frac{\operatorname{load}_{\mathrm{i}}+\left(\frac{\mathrm{kg}}{\mathrm{s}}\right)+\operatorname{load}_{\mathrm{i}+1}\left(\frac{\mathrm{kg}}{\mathrm{s}}\right)}{2}\right) \times\left(\operatorname{Time}_{\mathrm{i}+1}(\mathrm{~s})-\mathrm{Time}_{\mathrm{i}}(\mathrm{s})\right) \text { eq. } 2
$$



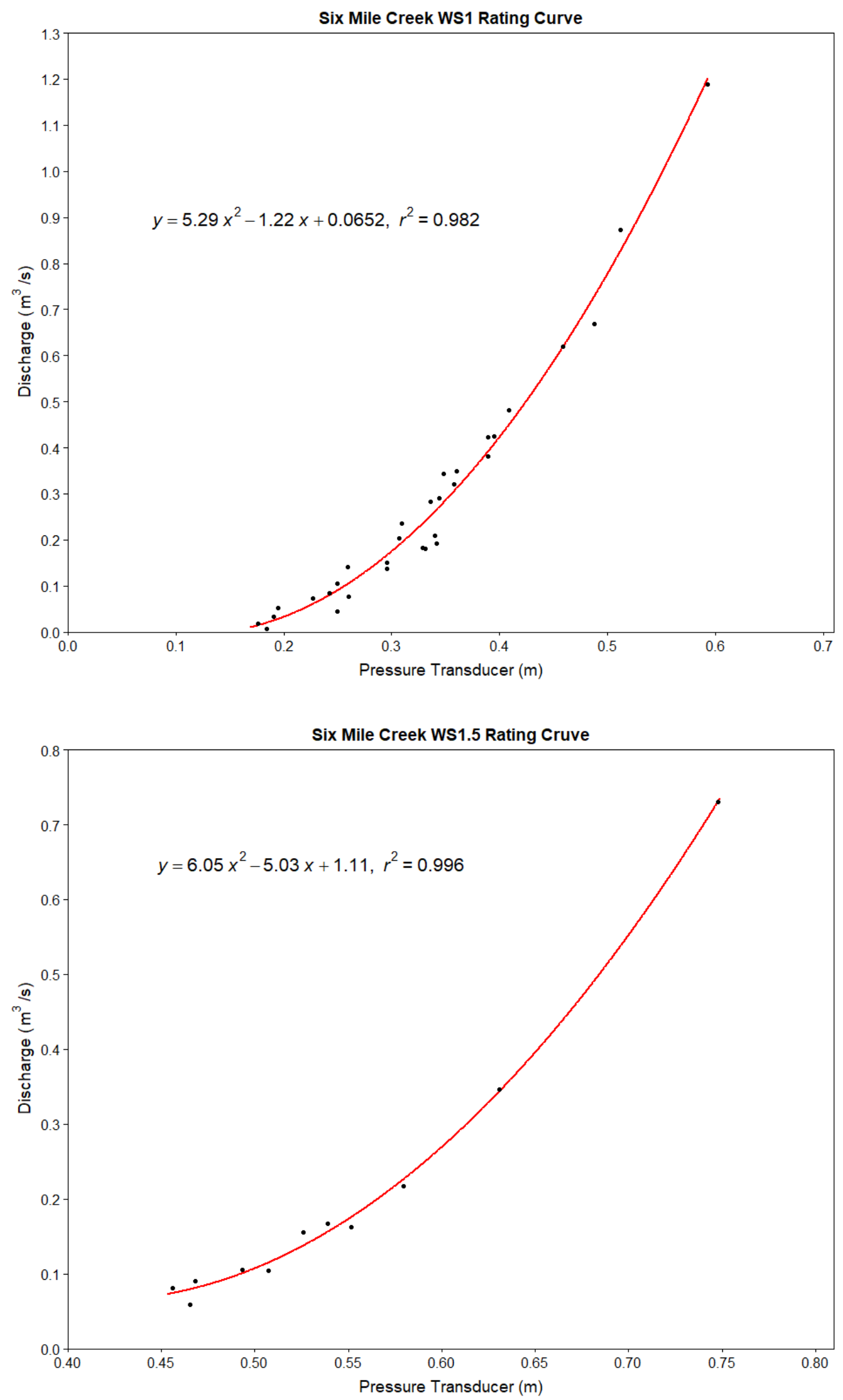

Figure 2. Rating curves for Six Mile Creek at WS1 and WS1.5. 

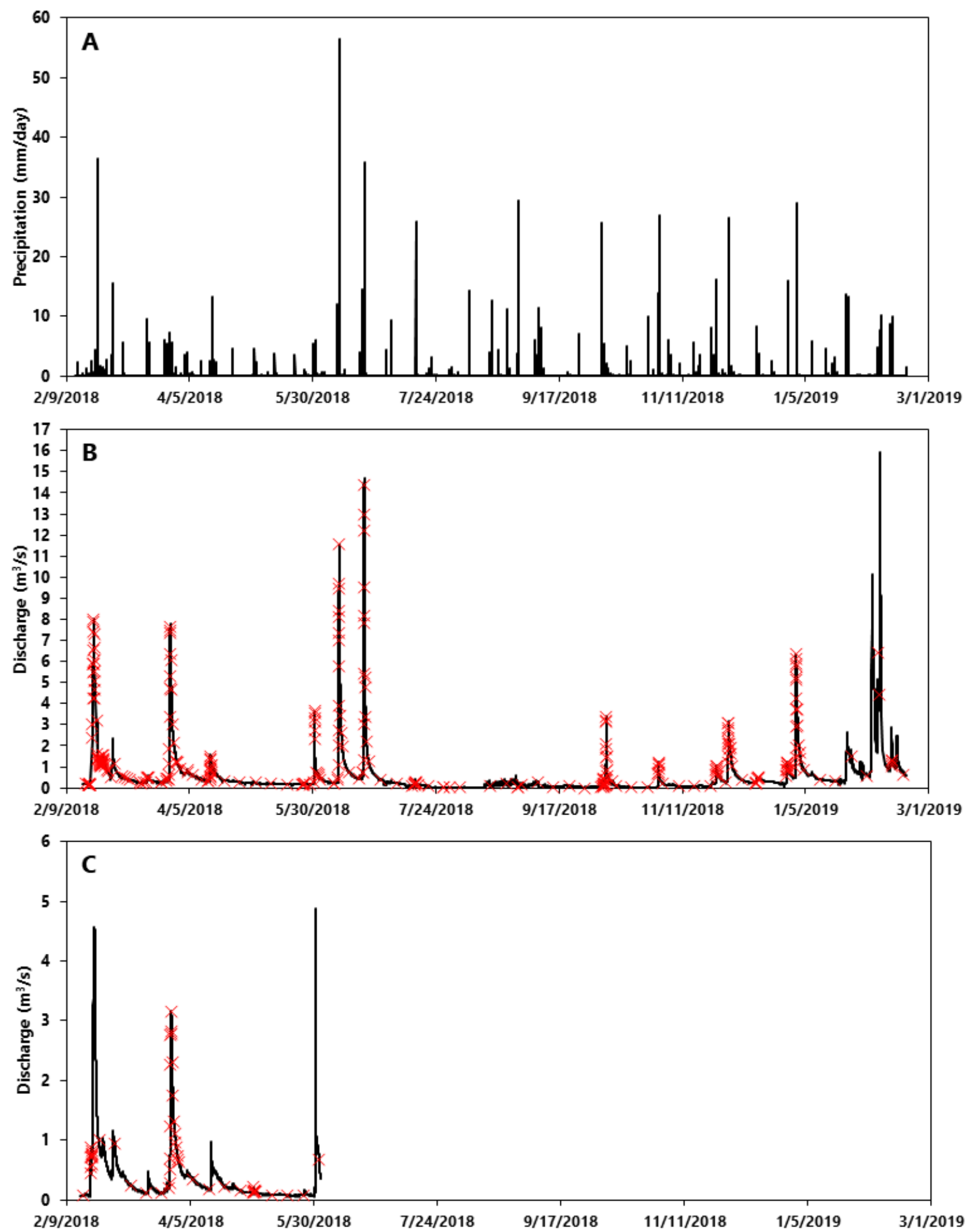

Figure 3. (A) Daily precipitation, (B) calculated discharge at WS1, and (C) calculated discharge WS1.5 during the study period. Precipitation data were collected using a rain gage at WS1. Sample collection points are marked with a red "x". 


\section{Background Concentrations}

Background concentrations of $\mathrm{Cl}^{-}, \mathrm{NO}_{3}-\mathrm{N}, \mathrm{K}^{+}$, and $\mathrm{Na}^{+}$were estimated using cumulative density curves to assess the impact of deicing and agricultural practices on waters in ELW (Panno et al., 2006b). This technique operates on the idea that the chemical composition of a water contains one or more populations (e.g. different source contributions) and that source contributions vary over time and space. A cumulative density curve is constructed by plotting the probability of a sample concentration relative to a sample set $(n>100)$. Different sources are represented as different slopes on this curve. The inflection points between slopes are called "threshold" values and represent the boundary between populations with the lowest population assumed to represent the natural background concentration.

\section{Box Plots, Timeseries, and Chemical Ratios}

Ratio plots $\left([\mathrm{X}]:\left[\mathrm{Cl}^{-}\right]\right)$and box plots with data categorized by location, season, and event or non-event sample were used to assess the difference between urban and agricultural waters as well as to identify $\mathrm{Cl}^{-}$sources. In particular, the ratios of $\mathrm{Cl}^{-}$to $\mathrm{Br}^{-}, \mathrm{NO}_{3}-\mathrm{N}$, and $\mathrm{Na}^{+}$are good indicators when assessing the source of $\mathrm{Cl}^{-}$in a water (Panno et al., 2006a; Panno et al., 2006b). Timeseries plots of the concentration of each major ion were also created to help assess seasonal differences between urban and agricultural waters as well as the role of storm events in the movement of ions through SMC. Storm events appear on timeseries plots as many samples in quick succession. A Mann-Whitney U test was performed to determine which $[\mathrm{Cl}]:[\mathrm{X}]$ ratios differed significantly $(\mathrm{p}<0.05)$ between urban (WS2 samples) and agricultural waters (tile-drain waters). 


\section{CHAPTER III: RESULTS}

\section{Overview}

A total of 525 samples were collected and analyzed during the study period (Appendices A and B). Number of samples, maximum, minimum, and median concentrations for select major ions $\left(\mathrm{Cl}^{-}, \mathrm{Br}^{-}, \mathrm{NO}_{3}-\mathrm{N}, \mathrm{Ca}^{2+}, \mathrm{Na}^{+}, \mathrm{K}^{+}\right)$sorted by sample location and type are shown in Table 1. These ions were chosen because they best exhibit the differences between agricultural and urban waters as well as indicate $\mathrm{Cl}^{-}$source. Mid-stream stations WS1.5 and WS1.25 were considered together when discussing major ion trends along SMC because the sample interval at each did not represent the entire study period, causing the statistics to be more biased toward seasonal concentration trends. Total precipitation measured during the study period at WS1 was $81.25 \mathrm{~cm}$.

Cumulative probability plots and threshold concentrations estimated using data collected during this study $(n=533)$ can be seen in Figure 4 . The background threshold concentrations for $\mathrm{NO}_{3}-\mathrm{N}, \mathrm{Cl}^{-}, \mathrm{Na}^{+}$, and $\mathrm{K}^{+}$were estimated to be $2.5,18.0,4.5$, and $0.5 \mathrm{mg} / \mathrm{l}$, respectively (Fig. 4). These background threshold estimates match those made by previous studies: $\mathrm{NO}_{3}-\mathrm{N}$ at $2.1-2.5$ mg/l in southwest and central Illinois (Peterson and Benning, 2013; Panno et al., 2006b); $\mathrm{Cl}^{-}$at 15 $\mathrm{mg} / \mathrm{l}$ in southwest Illinois (Panno et al., 2006b); $\mathrm{Na}^{+}$at 1.6-24 mg/l in northeastern Illinois (Panno et al., 2019; Hwang et al., 2015); $\mathrm{K}^{+}$at $0.5-3.0 \mathrm{mg} / \mathrm{l}$ in northeastern Illinois (Panno et al., 2019; Hwang et al., 2015).

At WS1, a total of 51 weekly sampling events were completed during the study period. The maximum and minimum discharge measured during weekly samplings were 1.19 and $0.001 \mathrm{~m}^{3} / \mathrm{s}$ respectively. A total of 21 storm events were sampled at WS1 until instrumentation was removed from the stream. There were 6 during the winter, 5 during the spring, 4 during the summer, and 6 during the fall. The maximum discharge calculated with the WS1 stage-discharge relationship was $15.95 \mathrm{~m}^{3} / \mathrm{s}$ and occurred during a storm event that began on February 3, 2019 (Fig. 3). 
At WS1.25, 26 weekly sampling events were completed from July 27, 2018 to February 17, 2019. A single storm was sampled during the fall at this station. The maximum and minimum measured discharge during weekly sampling events were 0.606 and $0.012 \mathrm{~m} 3 / \mathrm{s}$, respectively.

At WS1.5, 22 weekly sampling events were competed from February 16, 2018 to June 1, 2018. The maximum and minimum measured discharge during weekly sampling events were 0.730 and $0.058 \mathrm{~m}^{3} / \mathrm{s}$, respectively. There was one winter, and two spring storm events sampled at this station, with only the two spring events having sample coverage along the entire event hydrograph (Fig. 3). The latter of these two events that began April 6, 2018 did not trigger the auto sampler at WS1 making an upstream-downstream comparison impossible. The maximum discharge calculated with the WS1.5 stage-discharge relationship was $5.89 \mathrm{~m}^{3} / \mathrm{s}$ and occurred during a storm event that began on May 30, 2018 (Fig. 3).

At WS2, a total of 49 weekly sampling events were completed during the study period. The maximum and minimum measured discharge during sampling events were 0.248 and $0.001 \mathrm{~m}^{3} / \mathrm{s}$, respectively. A sample of road salt impacted road runoff was collected following the sampling procedure used for tile drains at this location on February 17, 2019. This sample had the highest measured $\mathrm{Cl}^{-}, \mathrm{Br}^{-}, \mathrm{Na}^{+}$, and $\mathrm{K}^{+}$concentrations at 31,000, 2.1, 17,500, and $62.9 \mathrm{mg} / \mathrm{l}$, respectively (Table 1).

Discharge from tile drains sampled in the ELW during the study period ranged from $5.0 \times 10^{-5}$ to $1.8 \times 10^{-3} \mathrm{~m}^{3} / \mathrm{s}$. Sampled tile drains in the ELW ceased flow during the late summer and began flowing again in late fall or early winter. There were 9 tile-drain water samples collected at WS1, 5 at WS1.25, 8 at WS2, 5 at T3, and 37 at T1. The 5 samples drawn from a shallow T3 well represent part of a monthly sampling regime from May to September of 2018. 
Weekly discharge measurements show that discharge increased with increasing stream distance downstream when SMC was flowing. There was an extended period of no discharge at each stream station from mid-July to early October 2018. At downstream stations (WS1.5, WS1.25, and WS1) this was the result of the loss of tile input (observed at sampled tiles in ELW) in the summer and fall. At WS2, the dry period was a result of loss of discharge from the storm water retention pond when its water level fell below the level of the pond outlet (Fig. 3A and B). Summer storms did cause short periods of minimal flow in SMC, although none restored tile input (Fig. 3A and B). Late summer and fall tile samples were all drawn from $\mathrm{T} 1$ as there was intermittent flow from this tile during the dry period. The stream partially froze over at all stations in early February 2019 due to extreme cold $\left(<-25^{\circ} \mathrm{C}\right)$ during a polar vortex. 

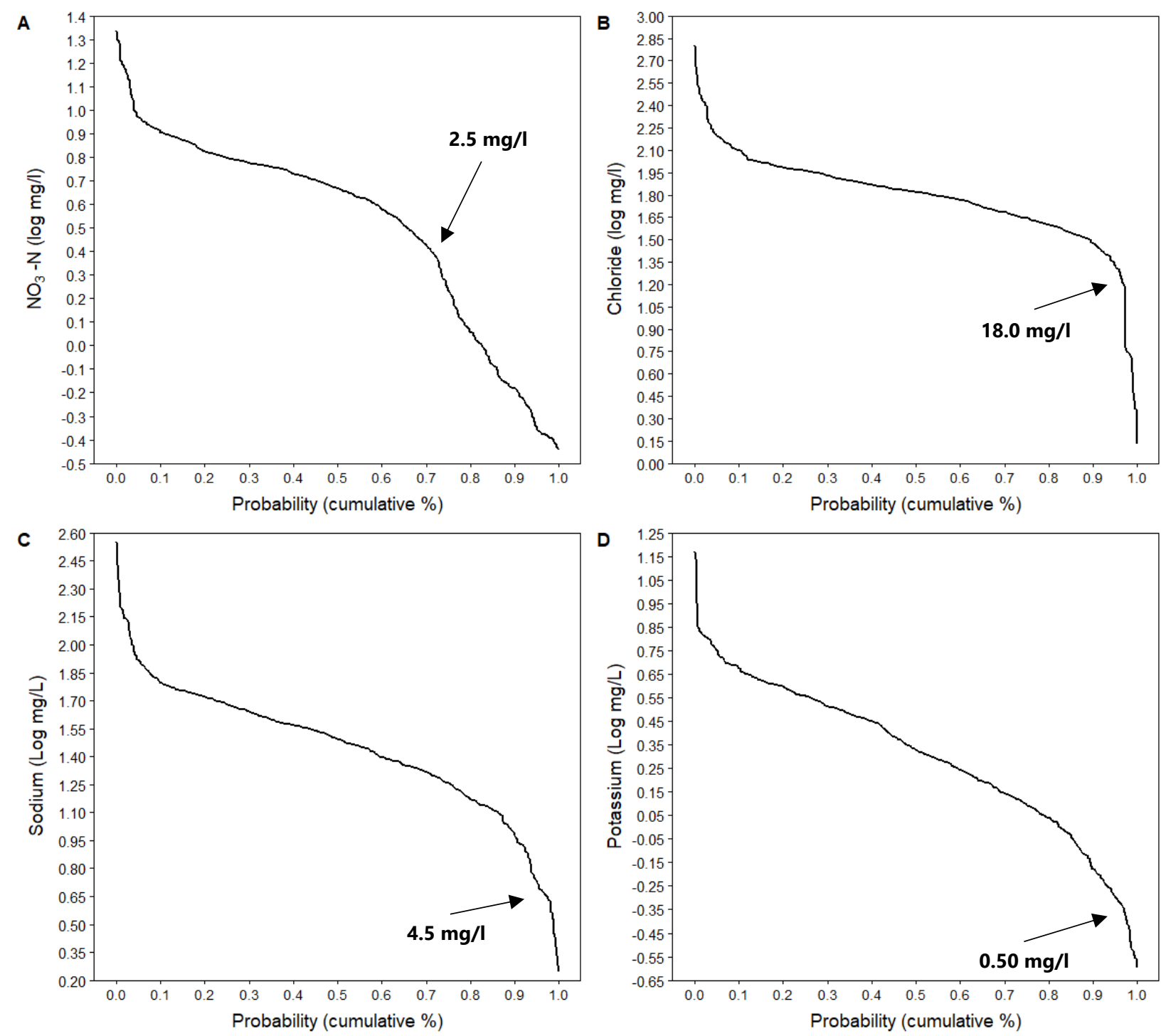

Figure 4. Cumulative probability curves for (A) $\mathrm{NO}_{3}-\mathrm{N}$, (B) $\mathrm{Cl}^{-}$, (C) $\mathrm{Na}^{+}$, and (D) $\mathrm{K}^{+}$with background threshold concentration labeled. The first inflection points for $\mathrm{NO}_{3}-\mathrm{N}, \mathrm{Cl}^{-}, \mathrm{Na}^{+}$, and $\mathrm{K}^{+}$are located at $\log \mathrm{mg} / \mathrm{l}$ concentrations of $0.40,1.25,0.65$, and -0.30 respectively. 
Table 1. Maximum, minimum, and median values for select ions in $\mathrm{mg} / \mathrm{l}$. Data are sorted by location/type. $\mathrm{n}$ indicates the number of samples.

\begin{tabular}{|c|c|c|c|c|c|c|c|}
\hline \multicolumn{2}{|c|}{ Location } & $\mathrm{Cl}^{-}$ & $\mathrm{Br}^{-}$ & $\mathrm{NO}_{3}-\mathrm{N}$ & $\mathrm{Ca}^{2+}$ & $\mathrm{Na}^{+}$ & $\mathbf{K}^{+}$ \\
\hline \multirow{3}{*}{$\begin{array}{r}\text { WS1 } \\
\text { n= } 315\end{array}$} & Median & 62.5 & $<0.05$ & 4.9 & 71.8 & 26.6 & 2.8 \\
\hline & Maximum & 346 & 0.3 & 9.9 & 242 & 193 & 7.3 \\
\hline & Minimum & 15.6 & $<0.05$ & 0.4 & 24.0 & 4.4 & 0.2 \\
\hline \multirow{3}{*}{$\begin{array}{r}\text { WS1.25 } \\
n=40\end{array}$} & Median & 65.7 & $<0.1$ & 0.6 & 70.4 & 37.9 & 2.8 \\
\hline & Maximum & 161 & 0.1 & 8.4 & 123 & 100 & 9.0 \\
\hline & Minimum & 36.0 & $<0.05$ & 0.4 & 17.6 & 12.8 & 1.1 \\
\hline \multirow{3}{*}{$\begin{array}{l}\text { WS1.5 } \\
\mathrm{n}=52\end{array}$} & Median & 77.8 & $<0.05$ & 6.0 & 76.7 & 38.2 & 1.4 \\
\hline & Maximum & 347 & 0.2 & 8.4 & 109 & 220 & 6.1 \\
\hline & Minimum & 47.1 & $<0.05$ & 0.4 & 43.4 & 11.1 & 0.3 \\
\hline \multirow{3}{*}{$\begin{array}{r}\text { WS2 } \\
\mathbf{n}=52\end{array}$} & Median & 84.4 & $<0.05$ & 1.7 & 56.2 & 42.9 & 2.0 \\
\hline & Maximum & 637 & 0.3 & 5.8 & 157 & 357 & 4.8 \\
\hline & Minimum & 27.8 & $<0.05$ & 0.0 & 6.9 & 20.0 & 0.6 \\
\hline \multirow{3}{*}{$\begin{array}{r}\text { Tile } \\
\mathrm{n}=64\end{array}$} & Median & 49.0 & $<0.05$ & 6.9 & 90.4 & 15.3 & 0.6 \\
\hline & Maximum & 464 & 0.2 & 21.7 & 211 & 269 & 14.8 \\
\hline & Minimum & 4.5 & $<0.05$ & 0.9 & 33.0 & 2.2 & 0.3 \\
\hline \multirow{3}{*}{$\begin{array}{l}\text { Well } \\
\mathrm{n}=5\end{array}$} & Median & 2.3 & 0.1 & 0.5 & 105 & 3.7 & 0.4 \\
\hline & Maximum & 3.0 & 0.3 & 0.7 & 127 & 6.0 & 1.8 \\
\hline & Minimum & 1.3 & 0.1 & 0.4 & 96.0 & 2.8 & 0.2 \\
\hline \multicolumn{2}{|c|}{ Deicing Runoff $(n=1)$} & 31000 & 2.1 & 4.7 & 73.6 & 17500 & 62.9 \\
\hline
\end{tabular}




\section{Water Chemistry and Chloride Ratios}

\section{Anions}

The median $\mathrm{Cl}^{-}$concentration was highest at WS2 at $84.4 \mathrm{mg} / \mathrm{l}$ and lowest in well water at $2.33 \mathrm{mg} / \mathrm{l}$ (Table 1). The median well $\mathrm{Cl}^{-}$concentration was the only one below the calculated background threshold. In tile drains the median $\mathrm{Cl}^{-}$concentration was $49.0 \mathrm{mg} / \mathrm{l}$, which is lower than the median values observed at any SMC station. The median $\mathrm{Cl}^{-}$concentration decreased downstream from WS2 to WS1 (Fig. 5). Tile drains had the second highest maximum $\mathrm{Cl}^{-}$ concentration at $464.02 \mathrm{mg} / \mathrm{l}$ after WS2 at $637 \mathrm{mg} / \mathrm{l}$. Downstream $\mathrm{Cl}^{-}$concentrations fell between those measured at WS2 and in tile drains (Fig. 6).

A spike in $\mathrm{Cl}^{-}$concentration of $\sim 70 \mathrm{mg} / \mathrm{l}$ was observed at WS2 from the end of July to midAugust (Fig. 6). During this time period there was no outflow from retention pond, but groundwater inflow maintained a small slow flowing pool of water at WS2 through the late summer and early fall when the downstream stations were stagnant or dry (Fig. 6). Elevated $\mathrm{Cl}^{-}$ was likely the result of WS2 groundwater having a higher $\mathrm{Cl}^{-}$concentration, normally diluted by pond outflow, and evaporative water loss from the pool. Water flowing out of this pool completely infiltrated or evaporated about 10 meters downstream.

$\mathrm{Cl}^{-}$concentrations exhibited a seasonal trend during the study period (Fig. 6). Concentrations were highest during the winter and early spring, particularly during periods of high flow associated with snowmelt or precipitation (Figs. 3 and 6). These concentrations never exceeded the EPA acute toxicity limit of $860 \mathrm{mg} / \mathrm{l}$, although the chronic limit of $230 \mathrm{mg} / \mathrm{l} \mathrm{was}$ exceeded for short time periods (hours to days) at WS1, WS1.5, WS2, and in tile discharge (Table 1). Late spring, summer, and fall precipitation, in contrast to winter, caused dilution of $\mathrm{Cl}^{-}$ concentration (Figs. 3 and 6). 
Over the course of this study, the median $\mathrm{NO}_{3}-\mathrm{N}$ concentrations were highest in tile drain water at $6.92 \mathrm{mg} / \mathrm{l}$ and lowest in well water at $0.46 \mathrm{mg} / \mathrm{l}$. (Table 1 and Fig. 5). Intermediate $\mathrm{NO}_{3^{-}}$ $\mathrm{N}$ concentrations were observed in SMC with median values ranging from $4.91 \mathrm{mg} / \mathrm{l}$ at WS1 to $1.72 \mathrm{mg} / \mathrm{l}$ at WS2 (Table 1 and Fig. 5). The median $\mathrm{NO}_{3}-\mathrm{N}$ concentration generally increased downstream from WS2 to WS1 (Figs. 5 and 7). Figure 5 appears to contradict this downstream trend as WS1.5 had a higher median $\mathrm{NO}_{3}-\mathrm{N}$ concentration than WS1 while WS1.25 had a lower median concentration than WS2. The apparent contradiction is the result of seasonal bias in the sample intervals for WS1.5 and WS1.25 as $\mathrm{NO}_{3}-\mathrm{N}$ concentrations were highest through the spring and early summer and lowest during the late winter and through mid-summer to early fall (Fig. 7). Elevated $\mathrm{NO}_{3}-\mathrm{N}$ concentrations were also observed in the late fall (Fig. 7). Mirroring $\mathrm{Cl}^{-}$, downstream $\mathrm{NO}_{3}-\mathrm{N}$ concentrations at WS1, WS1.25, and WS1.5 tended to fall between those measured at WS2 and in tile drains (Fig. 7). $\mathrm{NO}_{3}-\mathrm{N}$ concentrations were diluted by storm events (Figs. 3 and 7).

For samples with detectable $\mathrm{Br}^{-}, 118$ had concentrations below the detection limit of 0.05 $\mathrm{mg} / \mathrm{l}$. These samples were included on boxplots and ratio plots because values were consistent with waters measured in Illinois by Panno et al. (2005). Only well samples had a median and minimum $\mathrm{Br}^{-}$concentration above the $\mathrm{Br}^{-}$detection limit (Table 1). WS1 had the highest maximum $\mathrm{Br}^{-}$ concentration at $0.3 \mathrm{mg} / \mathrm{l}$. 

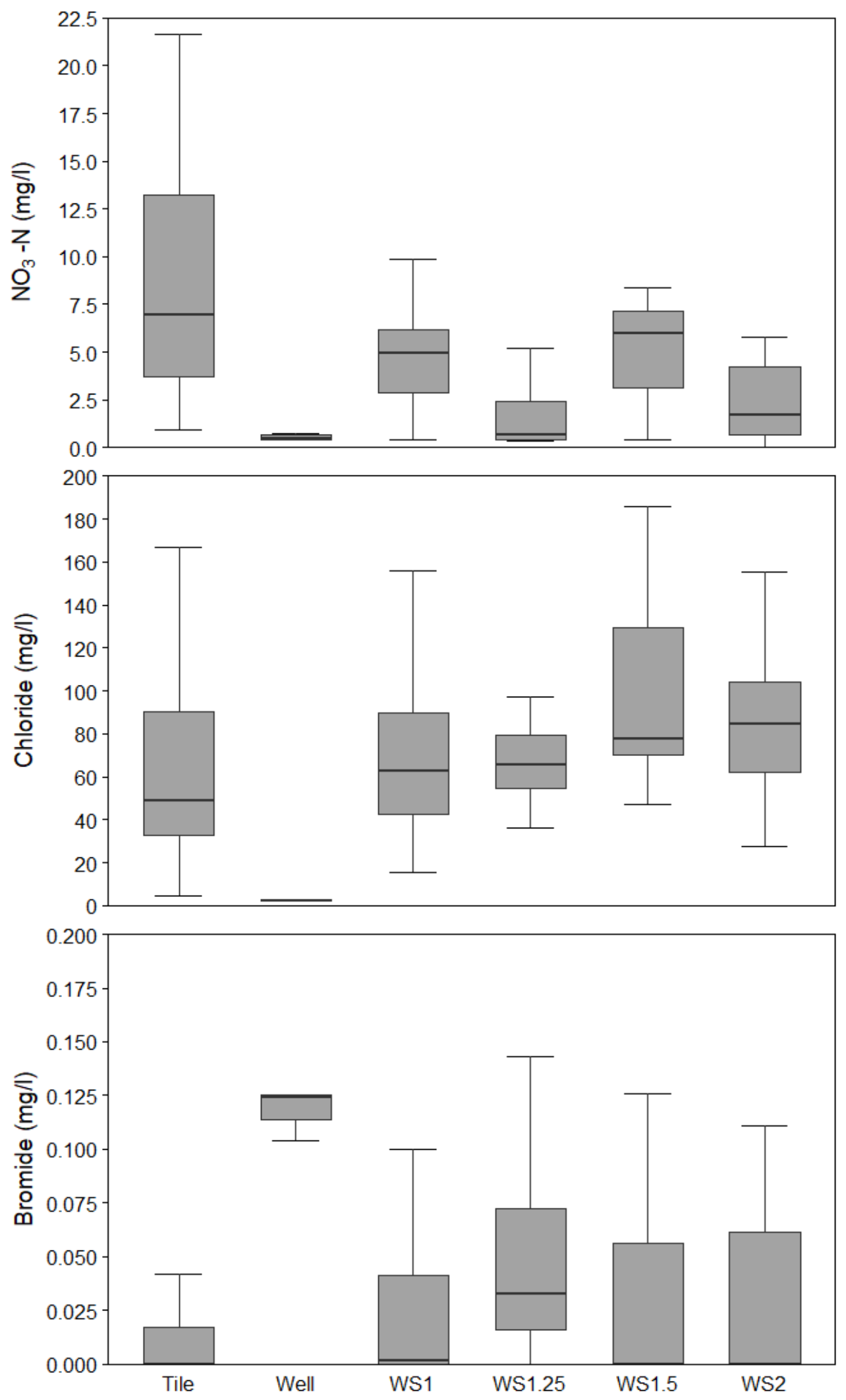

Figure 5. Boxplots for $\mathrm{NO}_{3}-\mathrm{N}, \mathrm{Cl}^{-}$, and $\mathrm{Br}^{-}$using data from all samples grouped by location or type (tile or well). Boxplots follow the standard Tukey definition. 


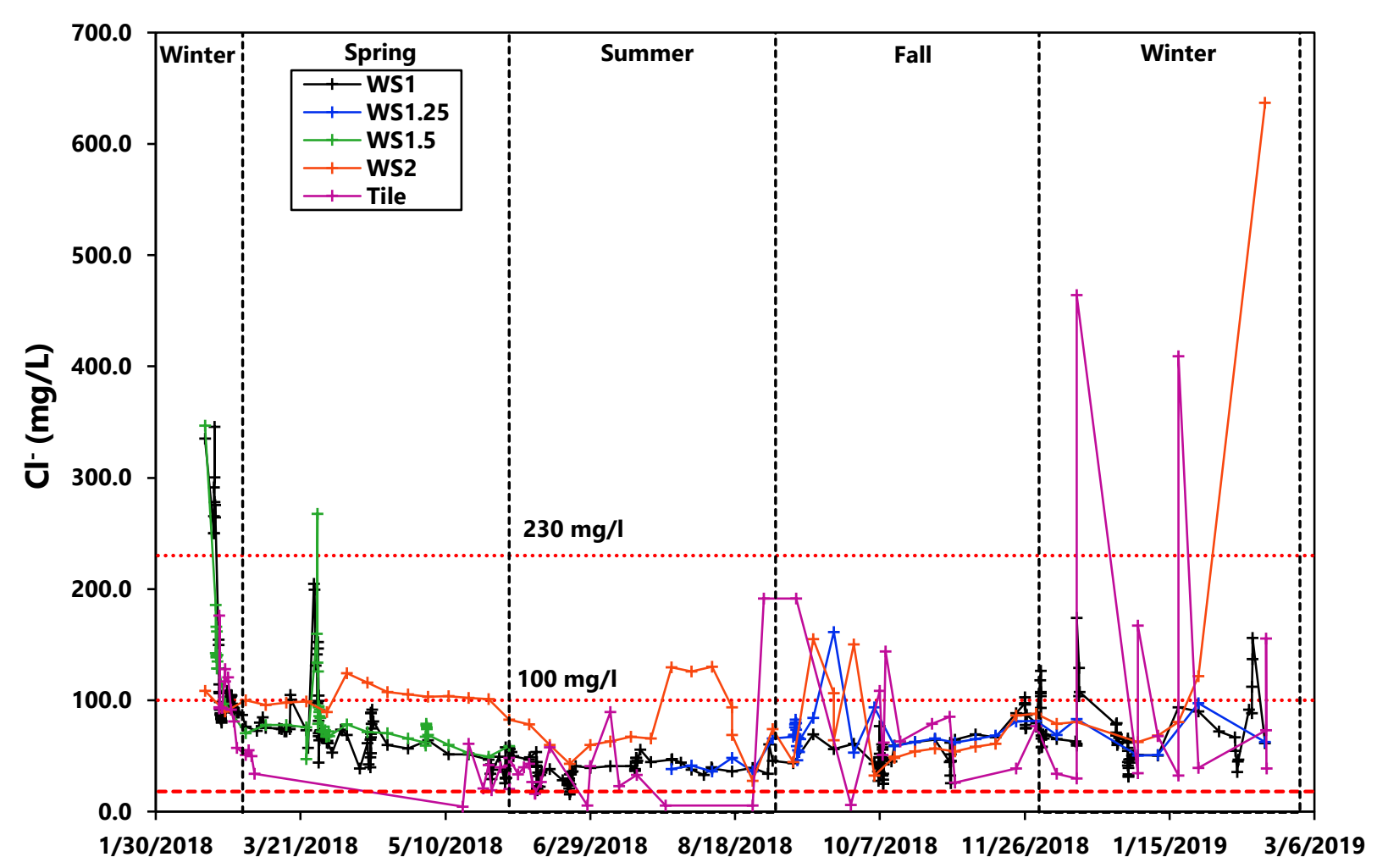

Figure 6. $\mathrm{Cl}^{-}$concentrations. The $230 \mathrm{mg} / \mathrm{l}$ chronic $\mathrm{Cl}^{-}$limit and $100 \mathrm{mg} / \mathrm{l}$ are marked as red dotted lines. A red dashed line marks the $18 \mathrm{mg} / \mathrm{l}$ background threshold. Black dashed vertical lines mark the seasons.

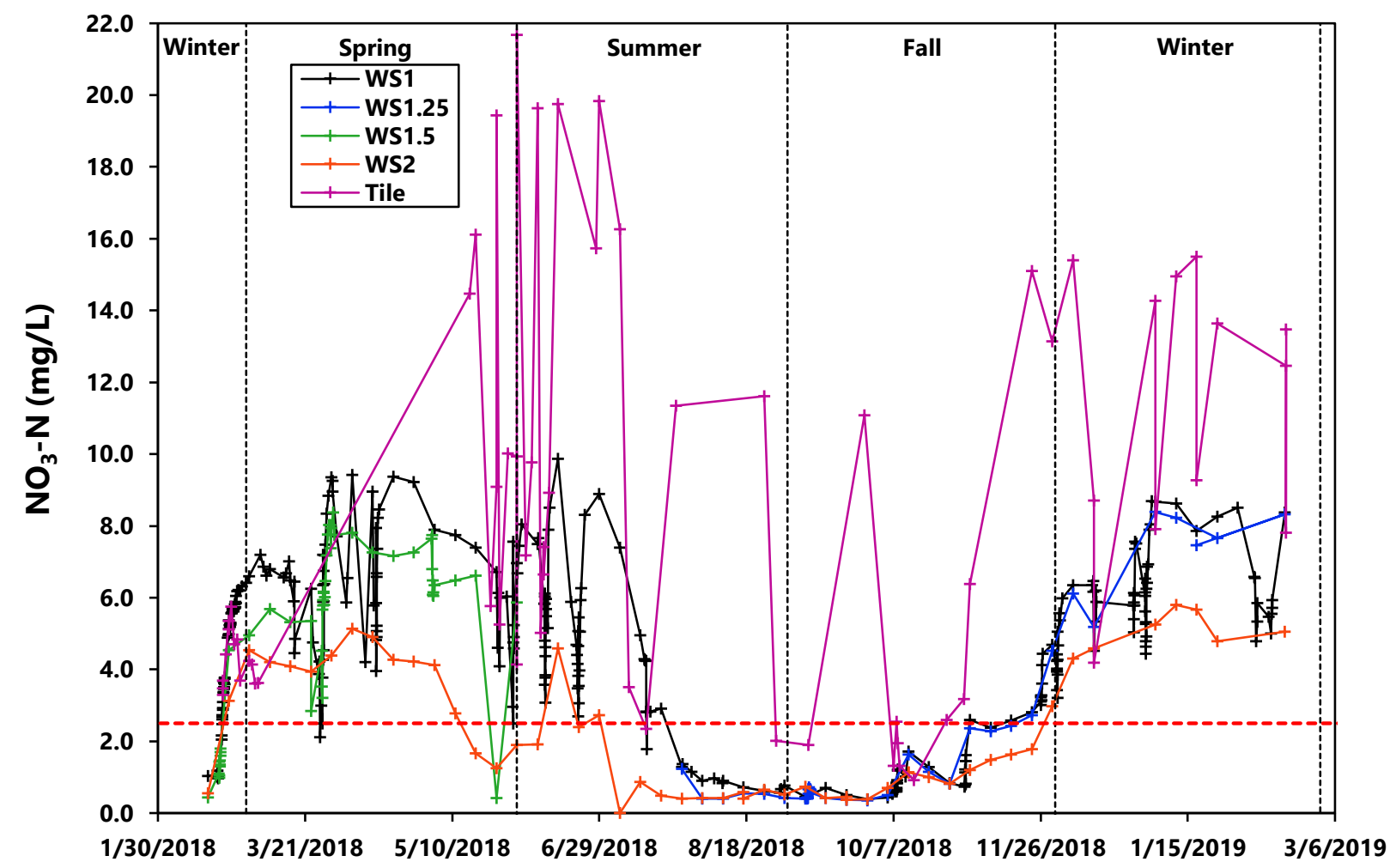

Figure 7. $\mathrm{NO}_{3}-\mathrm{N}$ concentrations. A red dashed line marks the $2.5 \mathrm{mg} / \mathrm{l}$ background threshold. Black dashed vertical lines mark the seasons. 


\section{Cations}

The median $\mathrm{K}^{+}$concentration was highest at WS1.5 at $2.81 \mathrm{mg} / \mathrm{l}$, but when WS1.25 and WS1.5 are considered together the highest median concentration is at WS1 at $2.77 \mathrm{mg} / \mathrm{l}$ (Table 1). The lowest median $\mathrm{K}^{+}$concentration was observed in well water at $0.39 \mathrm{mg} / \mathrm{l}$. The median $\mathrm{K}^{+}$ concentration increased downstream (Fig. 8), with the concentrations at intermediate stations falling between that observed at WS2 and in tile drains (Fig. 9). The highest $\mathrm{K}^{+}$concentration was measured at the end of October in $\mathrm{T} 1$ at $14.8 \mathrm{mg} / \mathrm{l}$, which coincided with elevated $\mathrm{K}^{+}$ concentrations observed at each stream station during the late summer and fall (Table 1 and Fig. 9). Elevated $\mathrm{K}^{+}$concentrations were also seen during the winter. Spikes in $\mathrm{K}^{+}$concentration were observed during storm events regardless of season (Figs. 3 and 9).

The concentration of $\mathrm{Na}^{+}$followed the same pattern as $\mathrm{Cl}^{-}$. Concentrations were highest during the winter and early spring, particularly during periods of high flow due to snowmelt or precipitation (Figs. 3 and 10). Late spring, summer, and fall precipitation, in contrast, caused dilution of $\mathrm{Na}^{+}$concentrations (Figs. 3 and 10). The highest median $\mathrm{Na}^{+}$concentration was at WS2 at $42.9 \mathrm{mg} / \mathrm{l}$ while the lowest was in well water at $3.68 \mathrm{mg} / \mathrm{l}$. WS2 had the highest maximum $\mathrm{Na}^{+}$ concentration at $357 \mathrm{mg} / \mathrm{l}$, followed by tile-drain waters at $269 \mathrm{mg} / \mathrm{l}$. An increase in $\mathrm{Na}^{+}$ concentration was seen during the fall in stream and tile waters (Fig. 10). The median $\mathrm{Na}^{+}$ concentration decreased downstream from WS2 (Fig. 8), with concentrations at WS1, WS1.25, and WS1.5 falling between concentrations measured at WS2 and in tile waters (Fig. 10).

The median $\mathrm{Ca}^{2+}$ concentration was highest in well water at $105 . \mathrm{mg} / \mathrm{l}$ and lowest at WS2 at $56.2 \mathrm{mg} / \mathrm{l}$ (Table 1). The median concentration of $\mathrm{Ca}^{2+}$ was higher in tile drain water at 90.4 $\mathrm{mg} / \mathrm{l}$ than at any stream station. Tile waters also exhibited the largest maximum $\mathrm{Ca}^{2+}$ concentration at $211 \mathrm{mg} / \mathrm{l}$ (Table 1). The median $\mathrm{Ca}^{2+}$ concentration tended to increase downstream from WS2

(Fig. 8). Strom events caused a dilution of $\mathrm{Ca}^{2+}$ concentration, with select storm events in the 
spring and early summer causing a spike in $\mathrm{Ca}^{2+}$ concentration after an initial dilution (Figs. 3 and 11). As with the other ions, the $\mathrm{Ca}^{2+}$ concentration in WS2, WS1.25, and WS1.5 waters plot between that in WS2 and tile waters (Fig. 11). During the late July to mid-August there was a 110 $\mathrm{mg} / \mathrm{l}$ spike in $\mathrm{Ca}^{2+}$ concentration at WS2 (Fig. 11). 

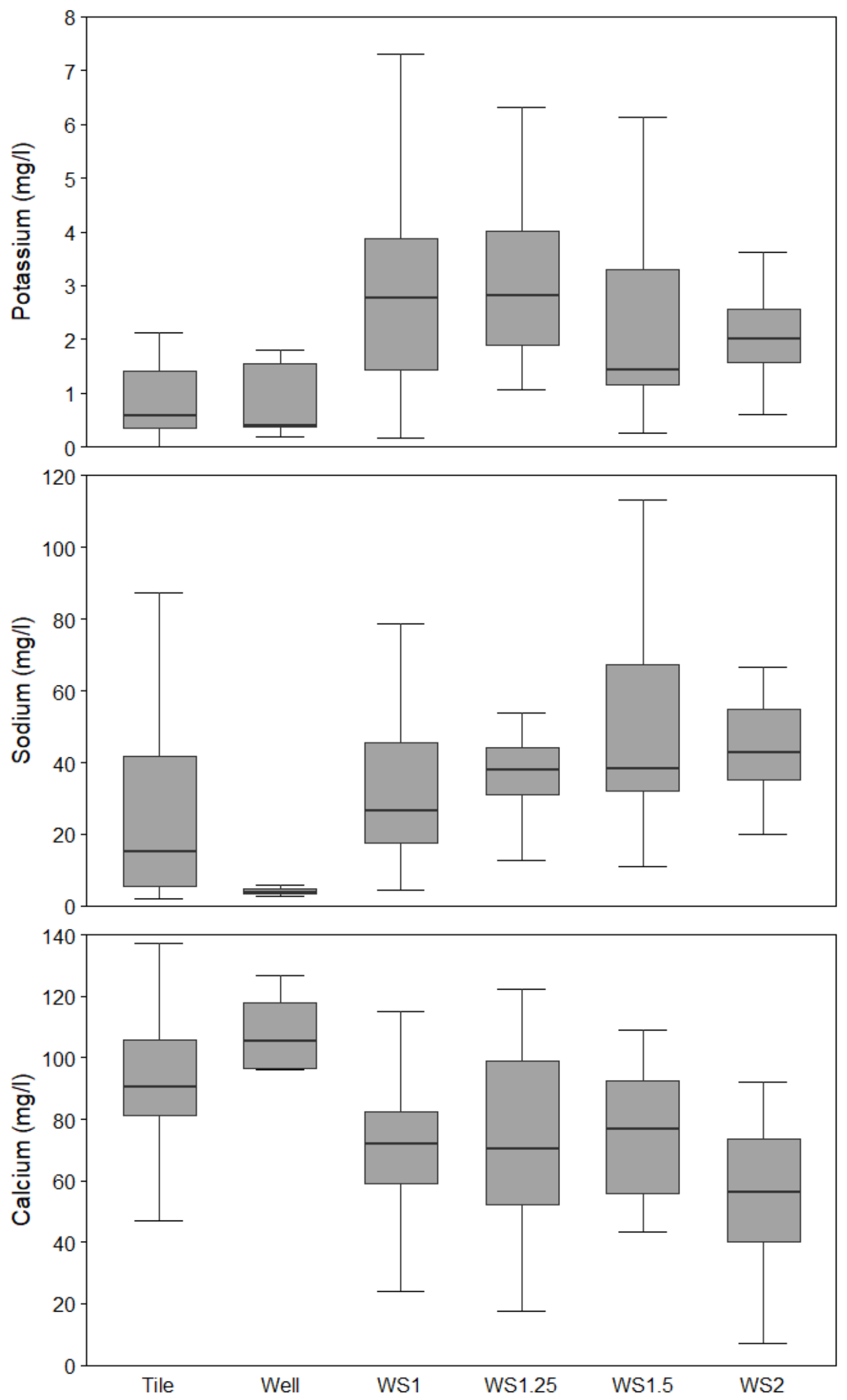

Figure 8. Boxplots for $\mathrm{Ca}^{2+}, \mathrm{Na}^{+}$, and $\mathrm{K}^{+}$using data from all samples grouped by location or type. Boxplots follow the standard Tukey definition. 


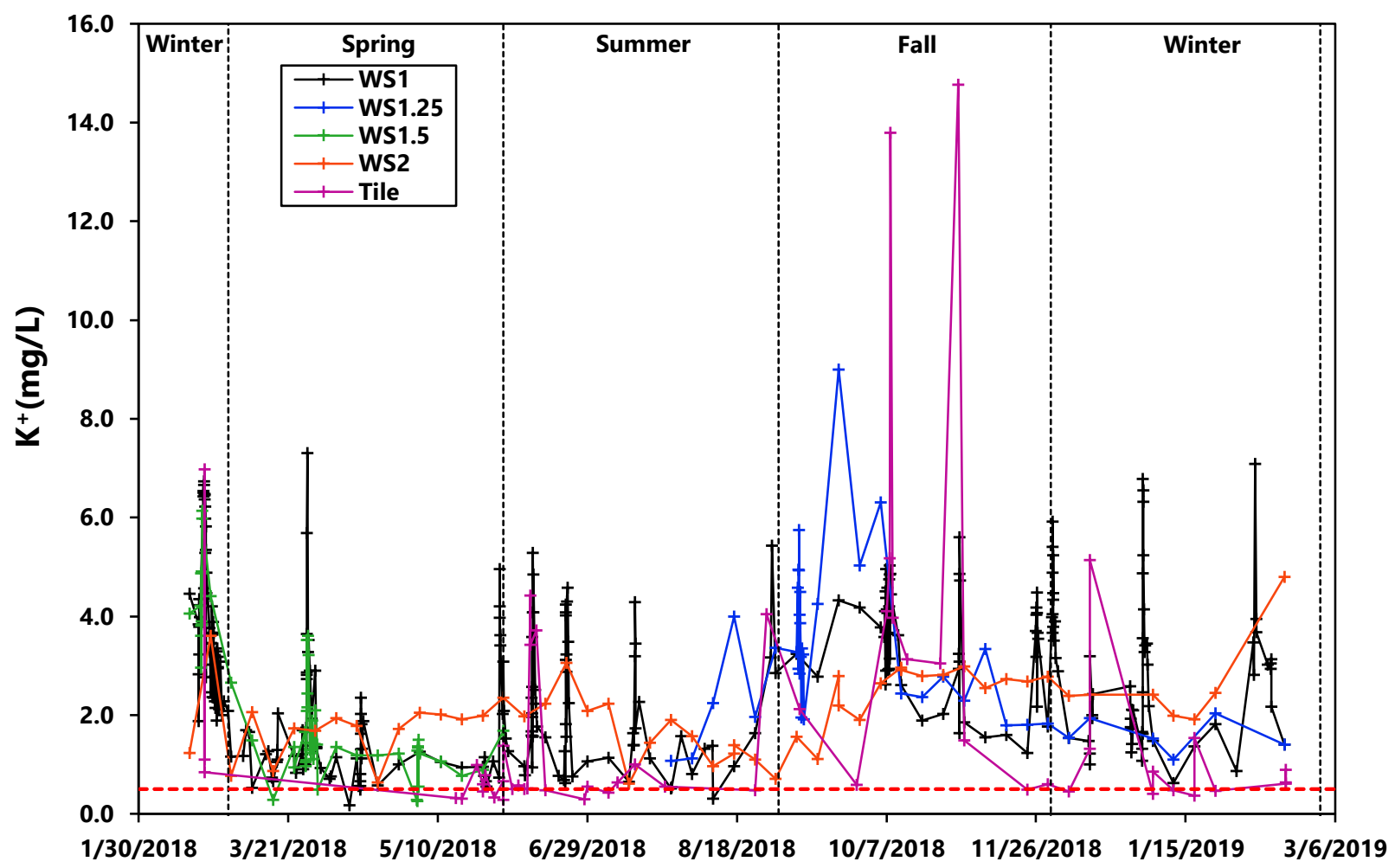

Figure 9. $\mathrm{K}^{+}$concentrations. A red dashed line marks the $0.5 \mathrm{mg} / \mathrm{l}$ background threshold. Black dashed vertical lines mark the seasons.

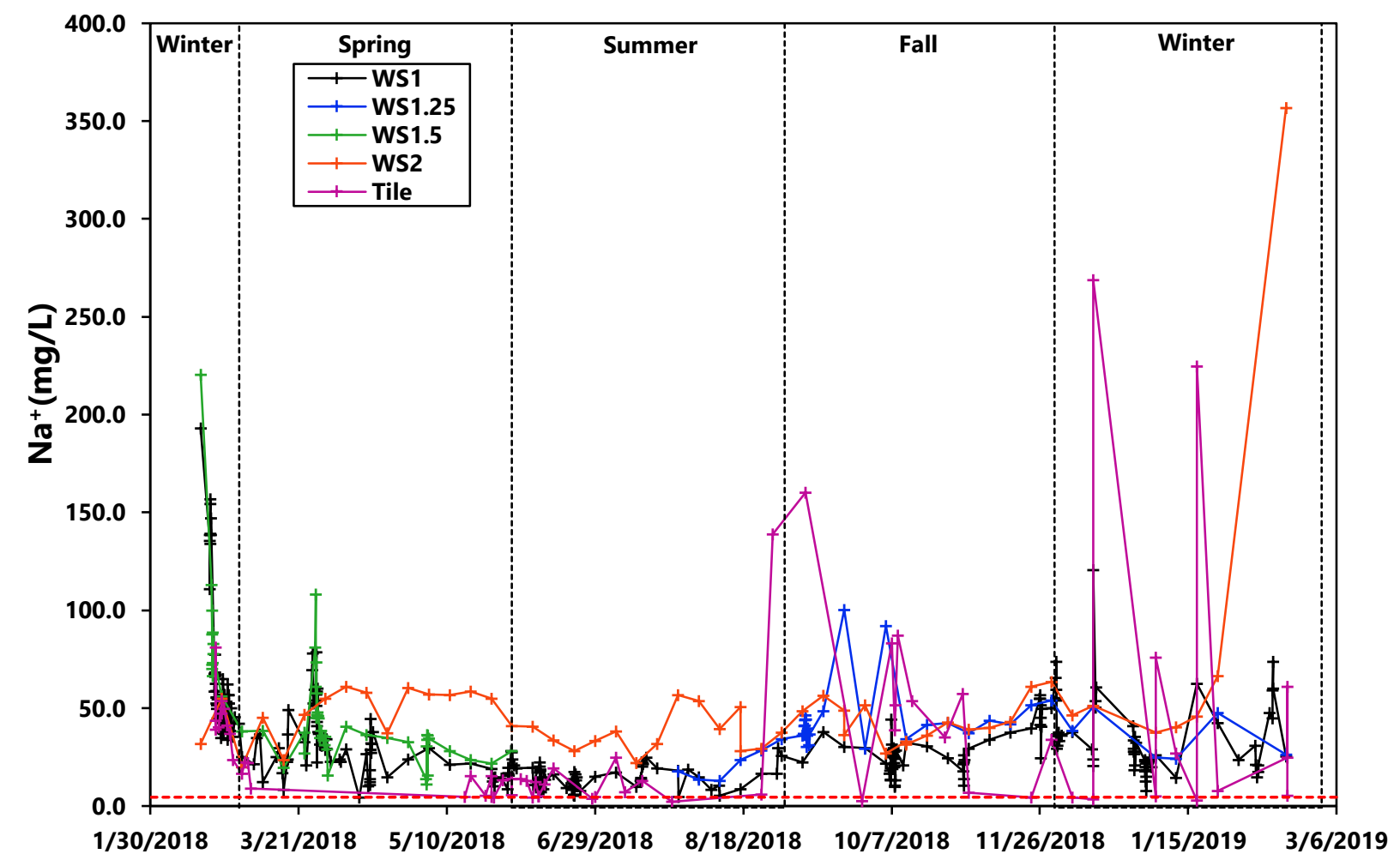

Figure 10. $\mathrm{Na}^{+}$concentrations. A red dashed line marks the $4.5 \mathrm{mg} / \mathrm{l}$ background threshold. Black dashed vertical lines mark the seasons. 


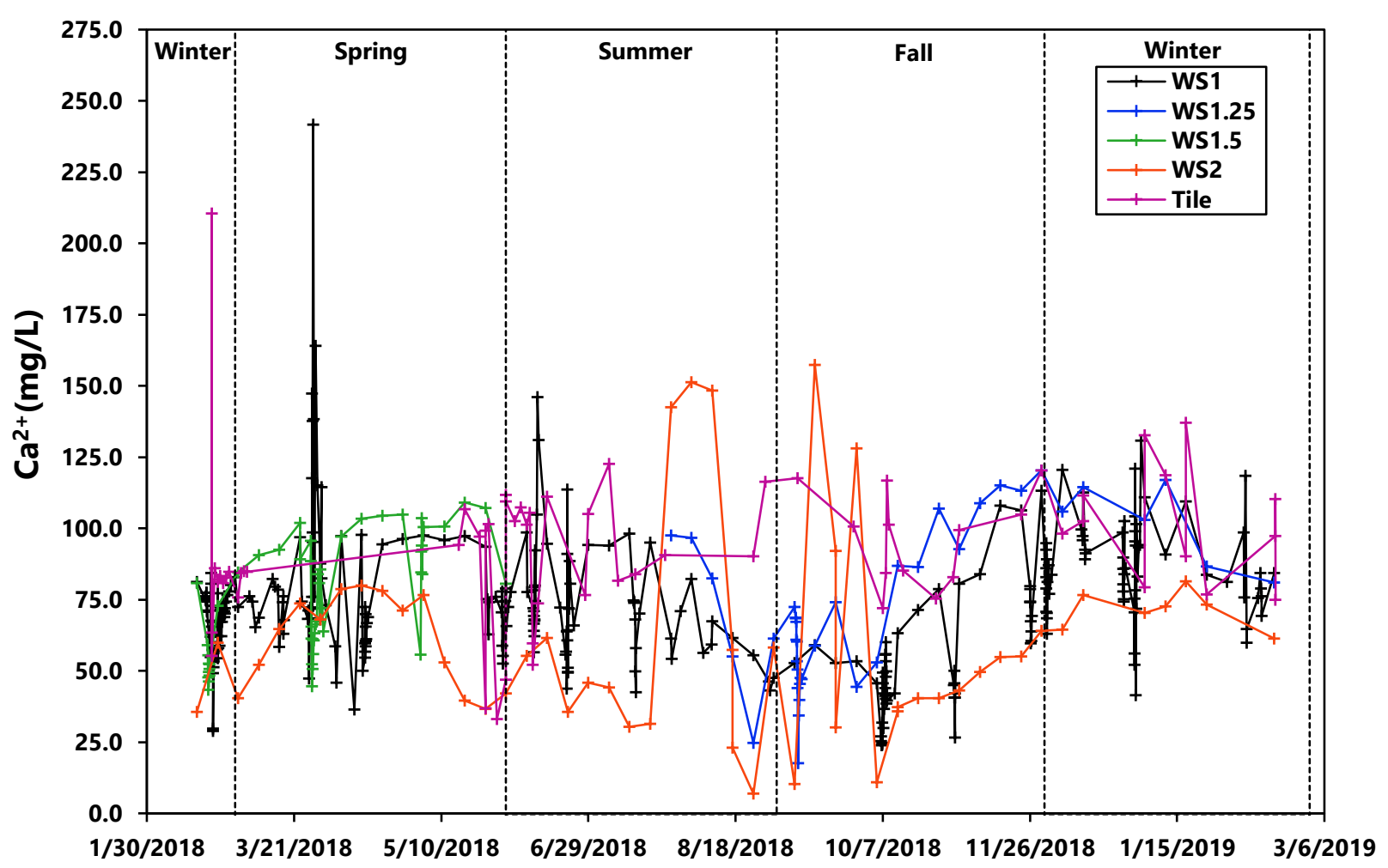

Figure 11. $\mathrm{Ca}^{2+}$ concentrations. Black dashed vertical lines mark the seasons. 


\section{Chloride Ratios and Ratio Plots}

None of the major ion or $\mathrm{Cl}^{-}$ratio populations were normally distributed. Normality was assessed by visual inspection of a density plot, Shapiro-Wilk test, and with Q-Q plots. The median, maximum, and minimum ratio values for WS2 and tile-drain waters can be found in Table 2. Mann-Whitney $\mathrm{U}$ tests reveal that the $\left[\mathrm{Cl}^{-}\right]:[\mathrm{X}]$ ratio is significantly different $(\mathrm{p}<0.05)$ between urban (WS2) and agricultural waters (tile drain) for all ratios except $\left[\mathrm{Cl}^{-}\right]:\left[\mathrm{K}^{+}\right]$(Table 2). The median ratio value was higher in urban waters than in tile waters for $\left[\mathrm{Cl}^{-}\right]:\left[\mathrm{Ca}^{2+}\right],\left[\mathrm{Cl}^{-}\right]:\left[\mathrm{Br}^{-}\right]$, and $\left[\mathrm{Cl}^{-}\right]:\left[\mathrm{NO}_{3}-\mathrm{N}\right]$, while tile waters exhibited a higher median ratio value for only $\left[\mathrm{Cl}^{-}\right]:\left[\mathrm{Na}^{+}\right]$(Table 2).

Ratio plots comparing the molar concentration of $\mathrm{Na}^{+}$to $\mathrm{Cl}^{-}$reveal that most samples plot on or just below the 1:1 line (Fig. 12). Spread along the 1:1 line and drift away from it vary by season (Fig 12A). Winter samples exhibit the most spread along the 1:1 line and only minimal drift below it. Fall samples also exhibit minimal drift below the 1:1 line but are not spread as wide as winter samples along it. Spring samples display the second widest spread along the 1:1 line. Spring and summer samples exhibit the most drift below the 1:1 line but separate along the line with springs samples plotting higher up the line than summer samples. Large drift below the 1:1 line occurs in some samples between 0.50 and $0.60 \mathrm{mg} / 1 \mathrm{Cl}^{-}$. Grouping samples by location/type reveals these samples are from tile drains, although many tile-drain waters plot closer to the 1:1 line at higher $\mathrm{Cl}^{-}$concentrations (Fig 12B). Well water plots above the line with the lowest $\mathrm{Na}^{+}$ and $\mathrm{Cl}^{-}$concentrations (Fig. 12B).

On $\mathrm{Cl}^{-}$vs $\mathrm{NO}_{3}-\mathrm{N}$ ratio plots indicate that almost all samples exceed the estimated background threshold $\mathrm{Cl}^{-}$concentration of $18.0 \mathrm{mg} / \mathrm{l}$ while a large portion of samples are still below the estimated $2.0 \mathrm{mg} / \mathrm{l}$ background threshold concentration for $\mathrm{NO}_{3}-\mathrm{N}$ (Fig. 13). Well water samples are the only ones that plot within the zone for pristine waters. Most tile-drain waters plot 
along the vector that indicates influence form nitrogen and anhydrous ammonia fertilizers, but several tile samples exhibit elevated $\mathrm{Cl}^{-}$concentrations and plot along the road salt or animal waste/septic effluent vectors (Fig. 13A). Stream samples tend to plot on the low end of the road salt or nitrogen and anhydrous ammonia fertilizer vectors (Fig. 13A). Tile and stream samples that plot high along the road salt vector were all collected in the winter (Fig. 13B). Overall, winter samples plot along an arc between the road salt vector and the nitrogen and anhydrous ammonia vector. Spring and summer samples make up the majority of stream samples that plot along the low end of the nitrogen and anhydrous ammonia fertilizer vector, while fall samples make up the majority of stream samples that plot along the low end of the road salt vector (Fig 13B). A few spring samples do, however, exhibit elevated $\mathrm{Cl}^{-}$concentrations on par with winter samples (Fig. 13B).

Most samples with measurable $\mathrm{Br}^{-}$were collected during storm events and plot in the road salt and septic effluent zone on a $\mathrm{Cl}^{-} / \mathrm{Br}^{-}$vs $\mathrm{Cl}^{-}$plot (Fig. 14). Tile drain waters are spread throughout the data cluster (Fig. 14A). Of samples that plot outside the road salt zone, some fall in the basin brine and animal waste domain below the main cluster while a larger number plot above the main cluster passing through the field tile zone into an undefined area on the plot. Only one tile sample plots in the field tile zone (Fig. 14A). All well samples and 5 tile water samples are classified as pristine aquifer water. Winter and spring samples tend to plot further into the road salt and septic effluent zone and trend towards the sample of road salt runoff (Fig. 14A/B). Fall and summer samples overlap with the tail end of the winter and spring sample cluster and plot more towards the field tile zone (Fig. 14B).

A K ${ }^{+}$vs $\mathrm{Cl}^{-}$molar ratio plot shows that nearly all samples collected during this study plot far below a 1:1 line (Fig. 15). Well water and some tile samples are the only ones to approach the 
1:1 line (Fig.15). Stream samples from WS1 plot the closest to the 1:1 line of all stream stations (Fig. 15). The molar ratio plot of $\mathrm{Ca}^{2+} \mathrm{vs} \mathrm{Cl}^{-}$shows most samples lie above a 2:1 line (Fig.16). A subset of samples plot on or below the 2:1 line (Fig. 16). These samples, most of which were collected during the winter and spring, form a trend away from the main data cluster (Fig. 16). 
Table 2. WS2 and tile-drain water molar $\mathrm{Cl}^{-}$ratio Mann-Whitney $\mathrm{U}$ test results. $\mathrm{P}<0.05$ denotes a significant difference between WS2 (urban) and tile-drain (agriculture) water sample populations. Median, maximum, and minimum $\left[\mathrm{Cl}^{-}\right]:[\mathrm{x}]$ ratio values are included.

\begin{tabular}{|c|c|c|c|}
\hline \multicolumn{2}{|c|}{ Ratio / p-value } & \multirow{2}{*}{$\begin{array}{r}\text { WS2 } \\
1.2\end{array}$} & \multirow{2}{*}{$\begin{array}{r}\text { Tile Drain } \\
1.6\end{array}$} \\
\hline $\mathrm{Cl}^{-} / \mathrm{Na}^{+}$ & Median & & \\
\hline $\mathrm{p}<0.0001$ & Maximum & 3.2 & 7.7 \\
\hline \multirow{4}{*}{$\begin{array}{r}\mathbf{C l}^{-} / \mathbf{K}^{+} \\
\mathrm{p}=0.059\end{array}$} & Minimum & 0.6 & 0.6 \\
\hline & Median & 50.4 & 68.2 \\
\hline & Maximum & 554 & 296 \\
\hline & Minimum & 13.4 & 4.0 \\
\hline \multirow{3}{*}{$\begin{array}{r}\mathbf{C l}^{-} / \mathbf{C a}^{2+} \\
\mathrm{p}<0.0001\end{array}$} & Median & 1.6 & 0.6 \\
\hline & Maximum & 11.7 & 4.7 \\
\hline & Minimum & 0.9 & 0.1 \\
\hline \multirow{3}{*}{$\begin{array}{r}\mathbf{C l}^{-} / \mathbf{B r}^{-} \\
\mathrm{p}=0.045\end{array}$} & Median & 1530 & 451 \\
\hline & Maximum & 18000 & 11500 \\
\hline & Minimum & 1090 & 63.0 \\
\hline \multirow{3}{*}{$\begin{array}{r}\mathbf{C l}^{-} / \mathbf{N O}_{3}{ }^{-} \\
\mathrm{p}<0.0001\end{array}$} & Median & 16.7 & 2.1 \\
\hline & Maximum & 153 & 43.8 \\
\hline & Minimum & 4.7 & 0.1 \\
\hline
\end{tabular}



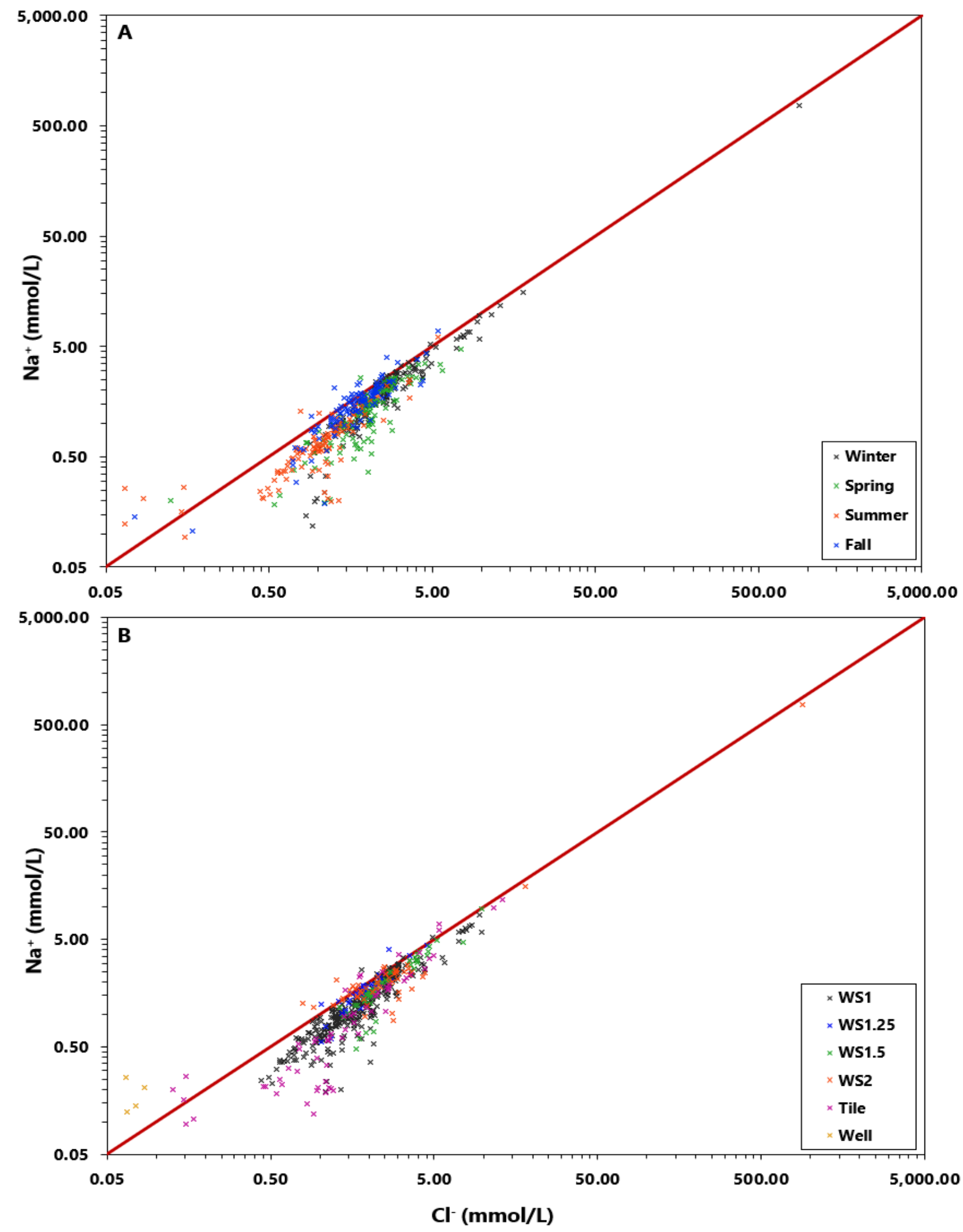

Figure 12. $\mathrm{Na}^{+}$vs. $\mathrm{Cl}^{-}$with 1:1 line in red. (A) Samples are grouped by season. (B) Samples grouped by location/type. 

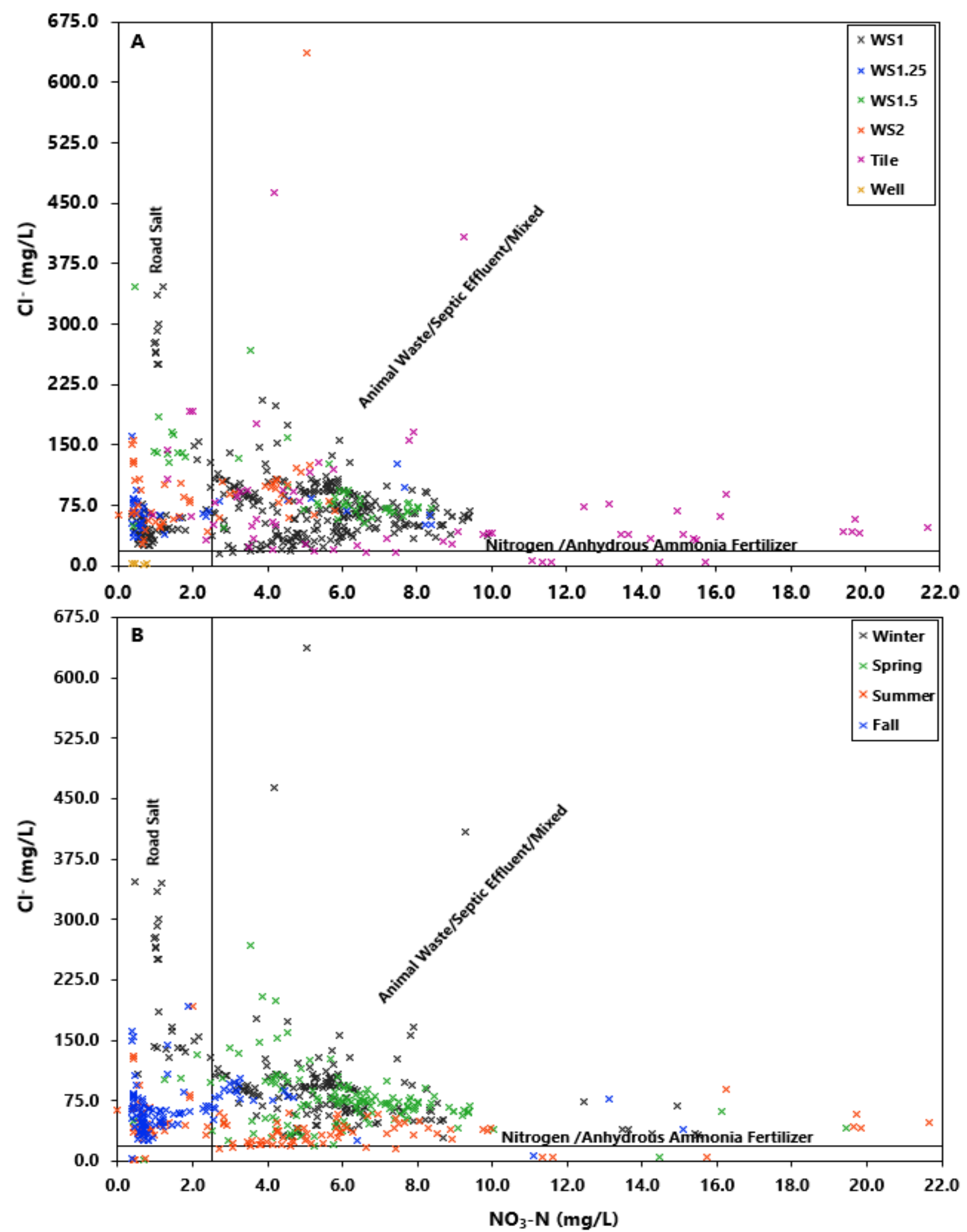

Figure 13. $\mathrm{Cl}^{-}$vs. $\mathrm{NO}_{3}-\mathrm{N}$ with samples grouped by (A) sample location/type and (2) season. Endmember vectors are labeled. Horizontal $\left(\mathrm{Cl}^{-}\right)$and vertical $\left(\mathrm{NO}_{3}-\mathrm{N}\right)$ lines represent background threshold concentrations and define a zone of pristine waters in the bottom left corner. 

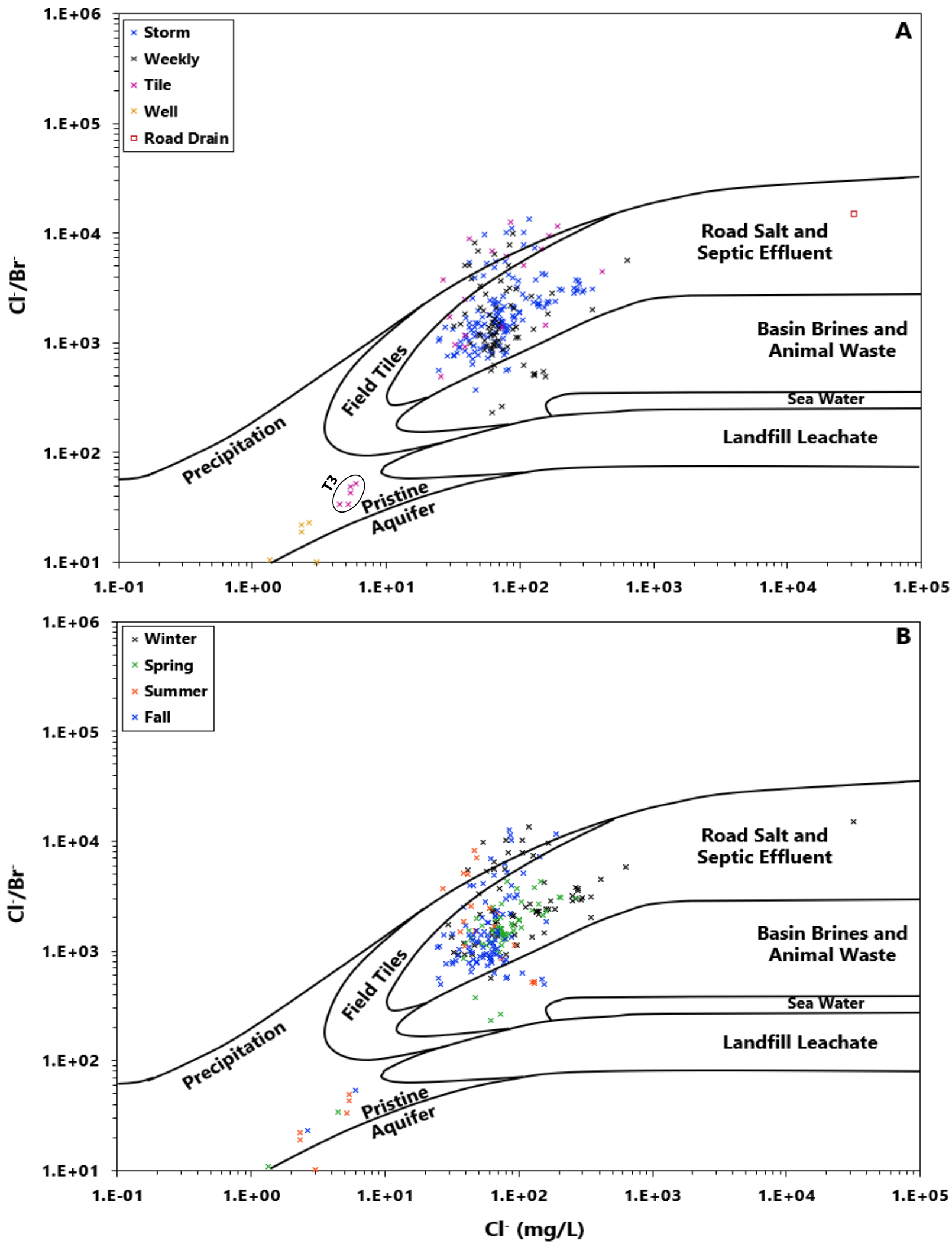

Figure 14. $\mathrm{Cl}^{-} / \mathrm{Br}^{-}$ratio vs. $\mathrm{Cl}^{-}$concentration for samples with measurable $\mathrm{Br}^{-}$. Samples are grouped by (A) storm/weekly with T3 tile samples labeled and (B) by season. Source domains are based off Panno et al. (2006a). 


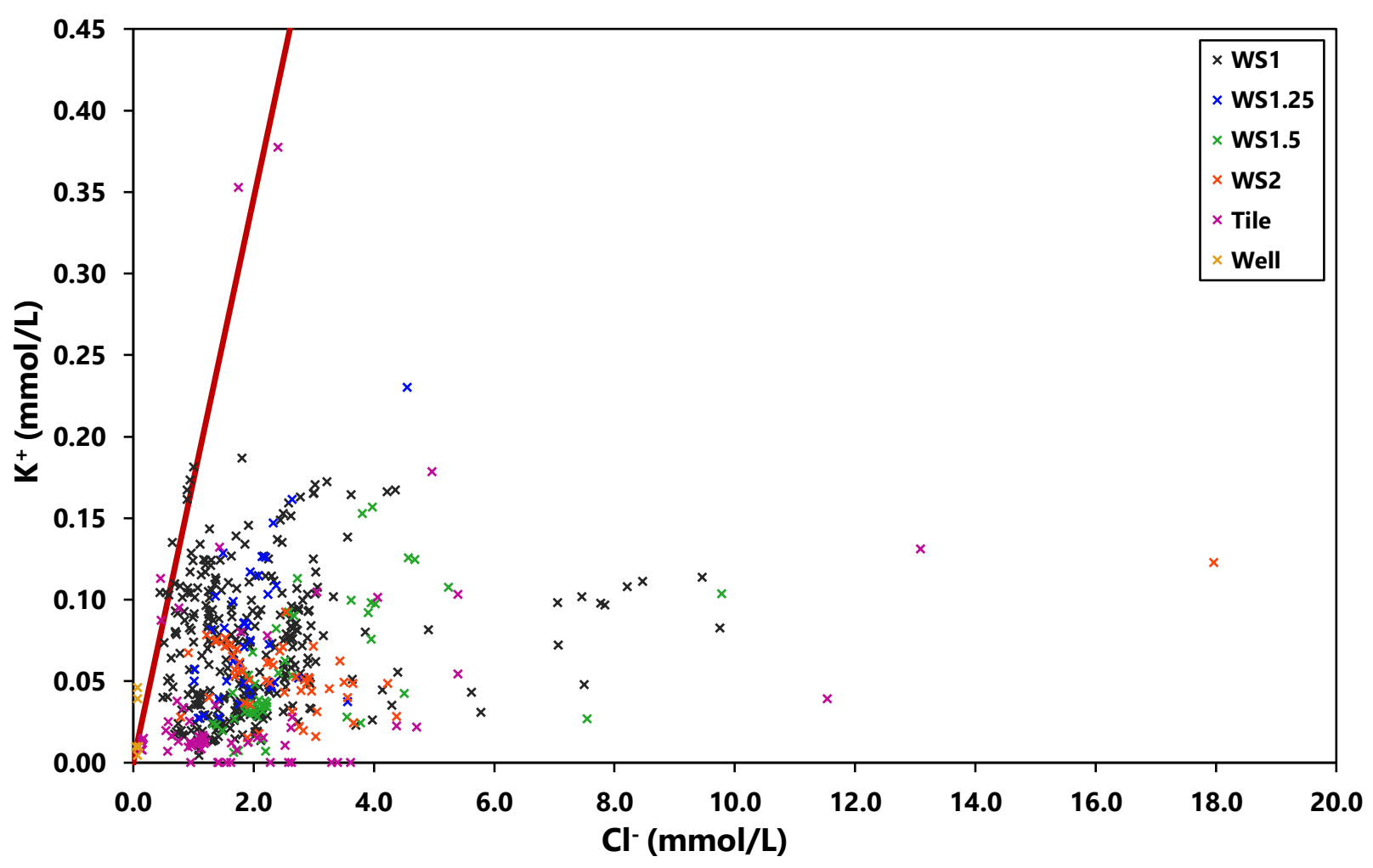

Figure 15. $\mathrm{K}^{+}$vs. $\mathrm{Cl}^{-}$with 1:1 in in red. Samples grouped by location/type.

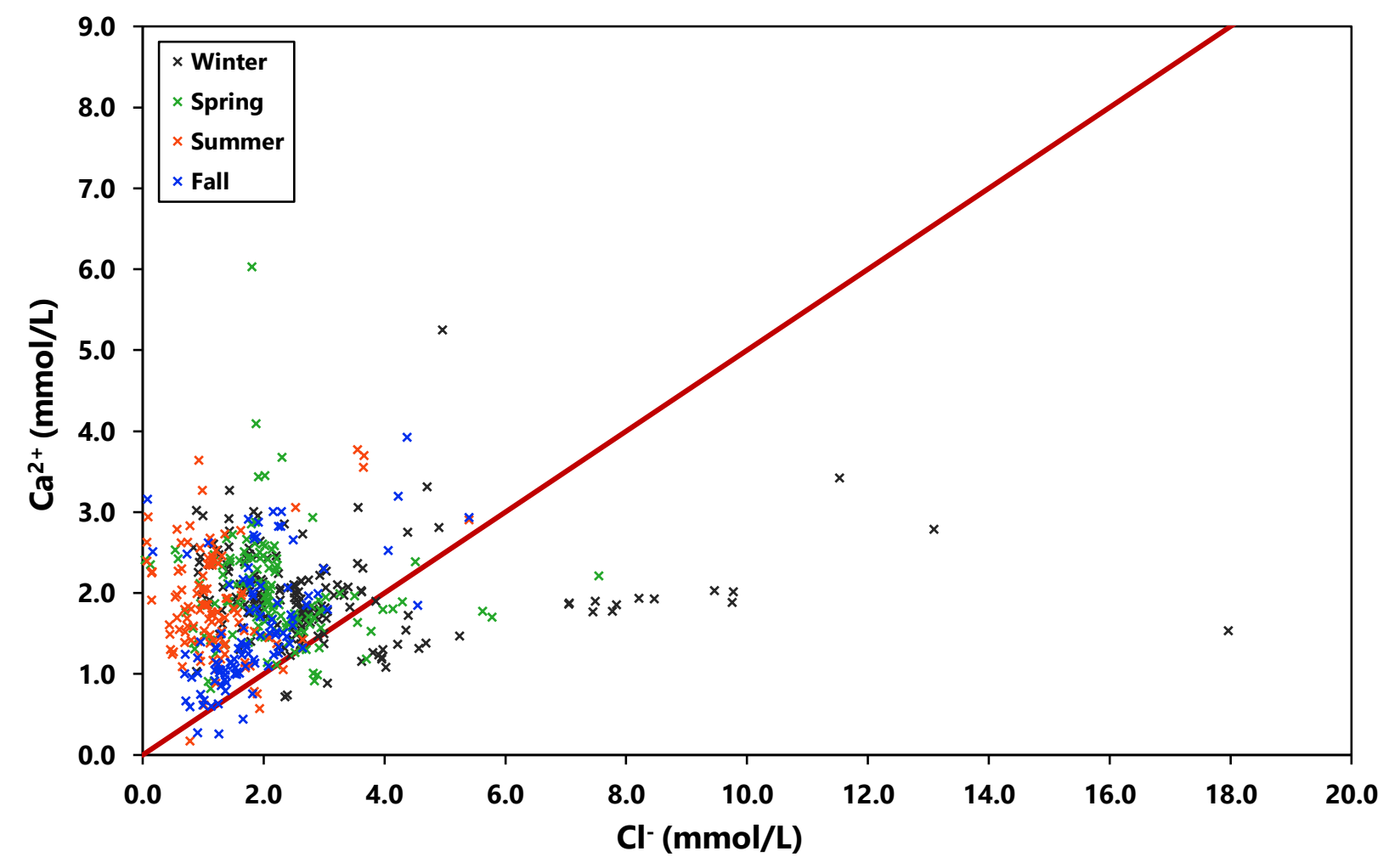

Figure 16. $\mathrm{Ca}^{2+}$ vs. $\mathrm{Cl}^{-}$with $2: 1$ line in red. Samples are grouped by season. 


\section{Chloride Transport}

Storm Events and Total $\mathrm{Cl}^{-}$Export

Total $\mathrm{Cl}^{-}$export for the calculation period (Feb. 16, 2018 to Jan. 25, 2019) at WS1 was $7.77 \times 10^{5} \mathrm{~kg}$ (Fig. 17A). $\mathrm{Cl}^{-}$export during storm events totaled $4.47 \times 10^{5} \mathrm{~kg}$, which makes up $57.5 \%$ of the total $\mathrm{Cl}^{-}$export. The total volume of water that flowed through SMC at WS1 for the calculation period was $1.25 \times 10^{7} \mathrm{~m}^{3}$ (Fig. 17B). Water volume attributed to storm events was $7.25 \times 10^{6} \mathrm{~m}^{3}$, which made up $58.0 \%$ of the total flow volume (Fig. 17B). A cumulative load plot illustrates that the largest contributions to $\mathrm{Cl}^{-}$load in SMC occur during storm events (Fig. 19). This is shown as a step pattern with brief and sharp upward steps during storm events followed by a period of gradual upward slope during non-event flow (Figs. 18 and 19). The cumulative load comparison for a spring storm (March 26 - April 1) at WS1 and WS1.5 indicates that the $\mathrm{Cl}^{-}$load in SMC increases with increasing stream distance (Fig. 19). Total export for this event at WS1 was $8.82 \times 10^{4} \mathrm{~kg}$ while at WS1.5 it was $5.03 \times 10^{4} \mathrm{~kg}$. During this event the period of peak discharge coincided with the period of peak $\mathrm{Cl}^{-}$loading (Fig. 19). At all points during this event the cumulative load was greater at WS1 (Fig. 19). This storm event was the second significant one to occur during the study period with the first taking place in February 2018 (Fig. 3B). Road salt and snow was present on watershed surfaces during the first major event, but it is unknown if further application occurred before the second storm. Conditions that could cause road ice to form (freezing temperatures and moisture) did occur between the two storms. 

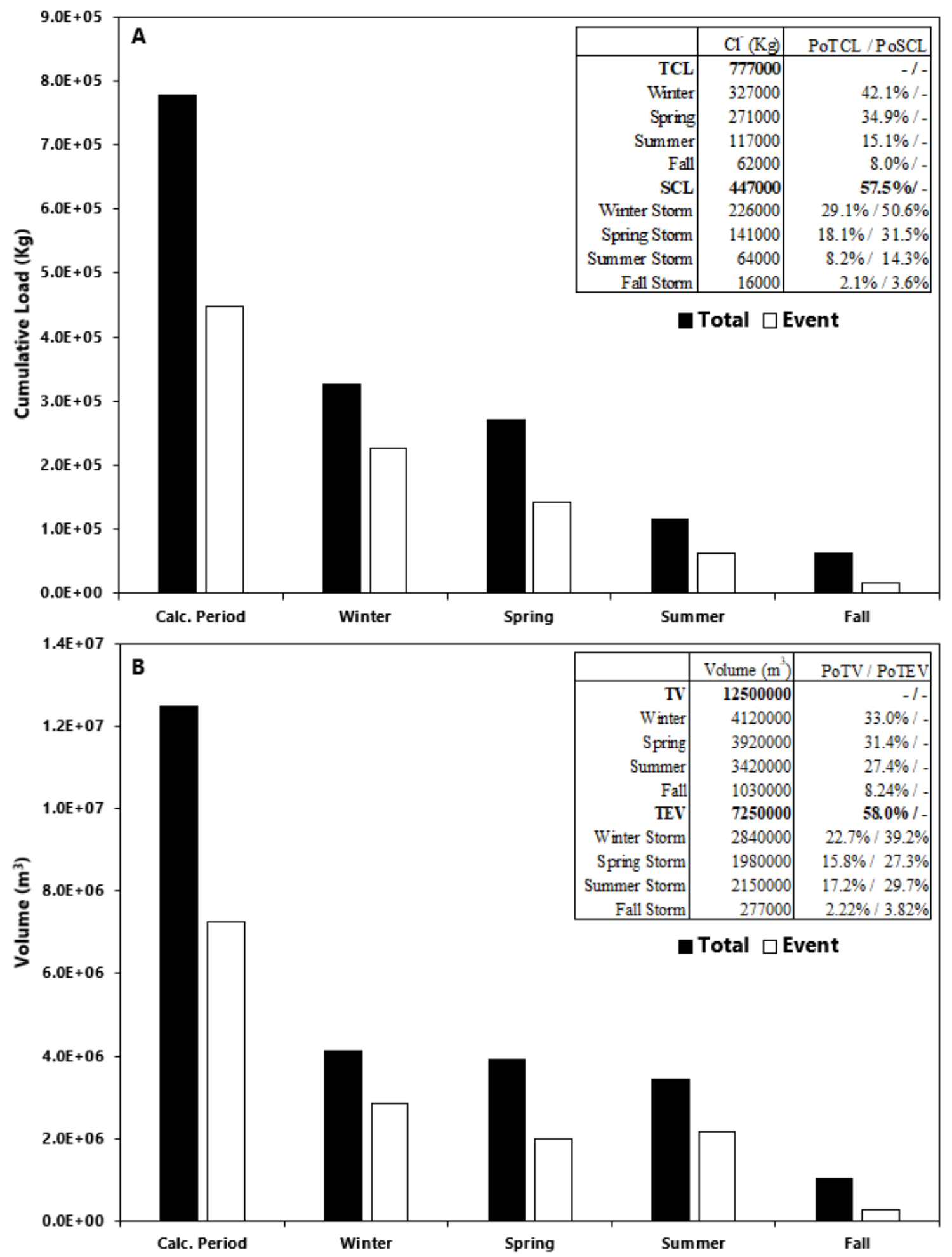

Figure 17. (A) Cumulative $\mathrm{Cl}^{-}$load by season and seasonal storm events during the calculation period at WS1 (TCL - Total cumulative load, SCL - Total storm cumulative load, PoTCL - Percent of total cumulative load, PoSCL - Percent of total storm cumulative load). (B) Discharge volume by season and seasonal storm events during the calculation period at WS1 (TV - Total volume, TEV - Total event volume, PoTV - Percent of total volume, PoTEV - Percent of total event volume). 


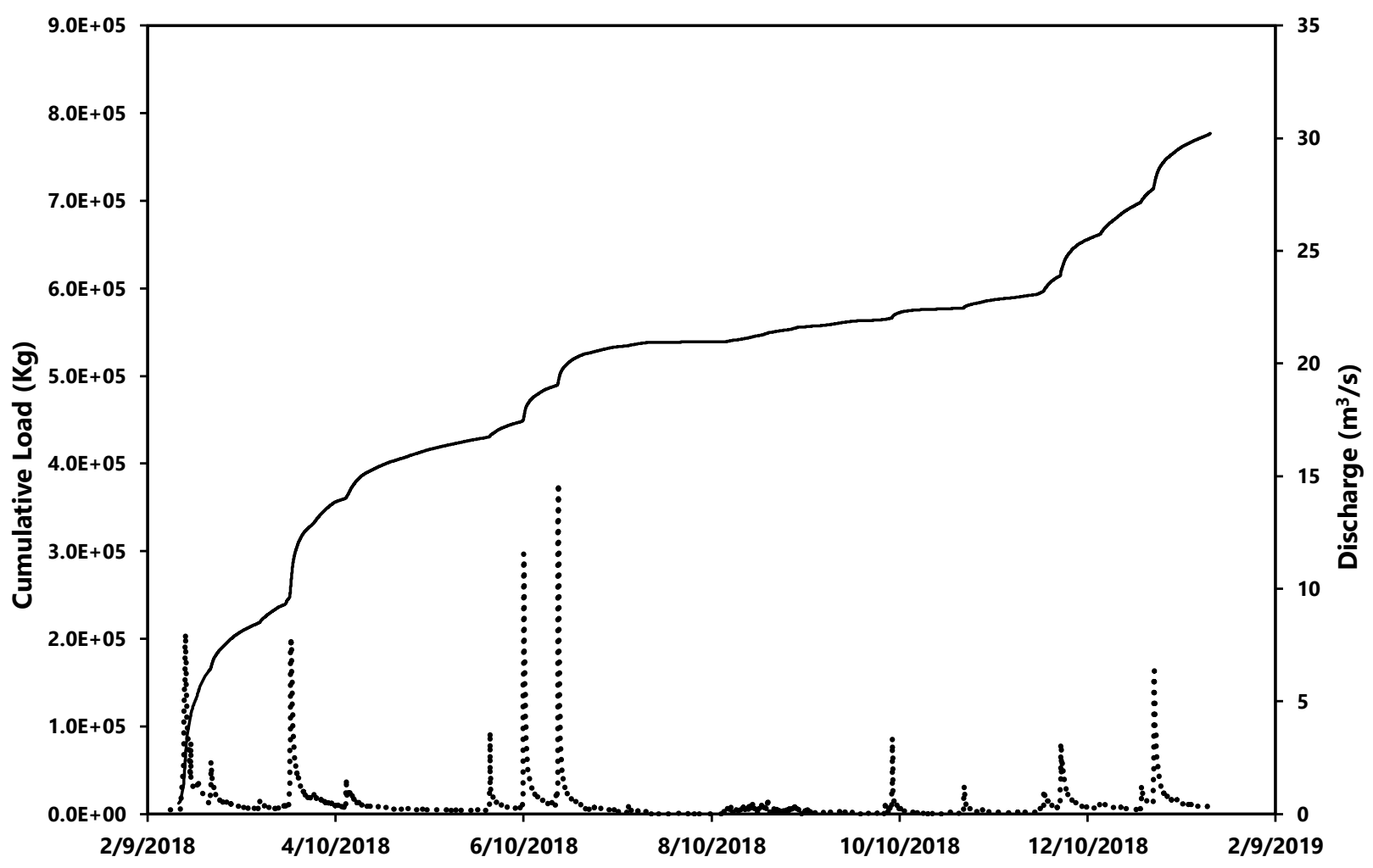

Figure 18. Cumulative load (solid line) and hydrograph (dotted line) at WS1 for the calculation period.

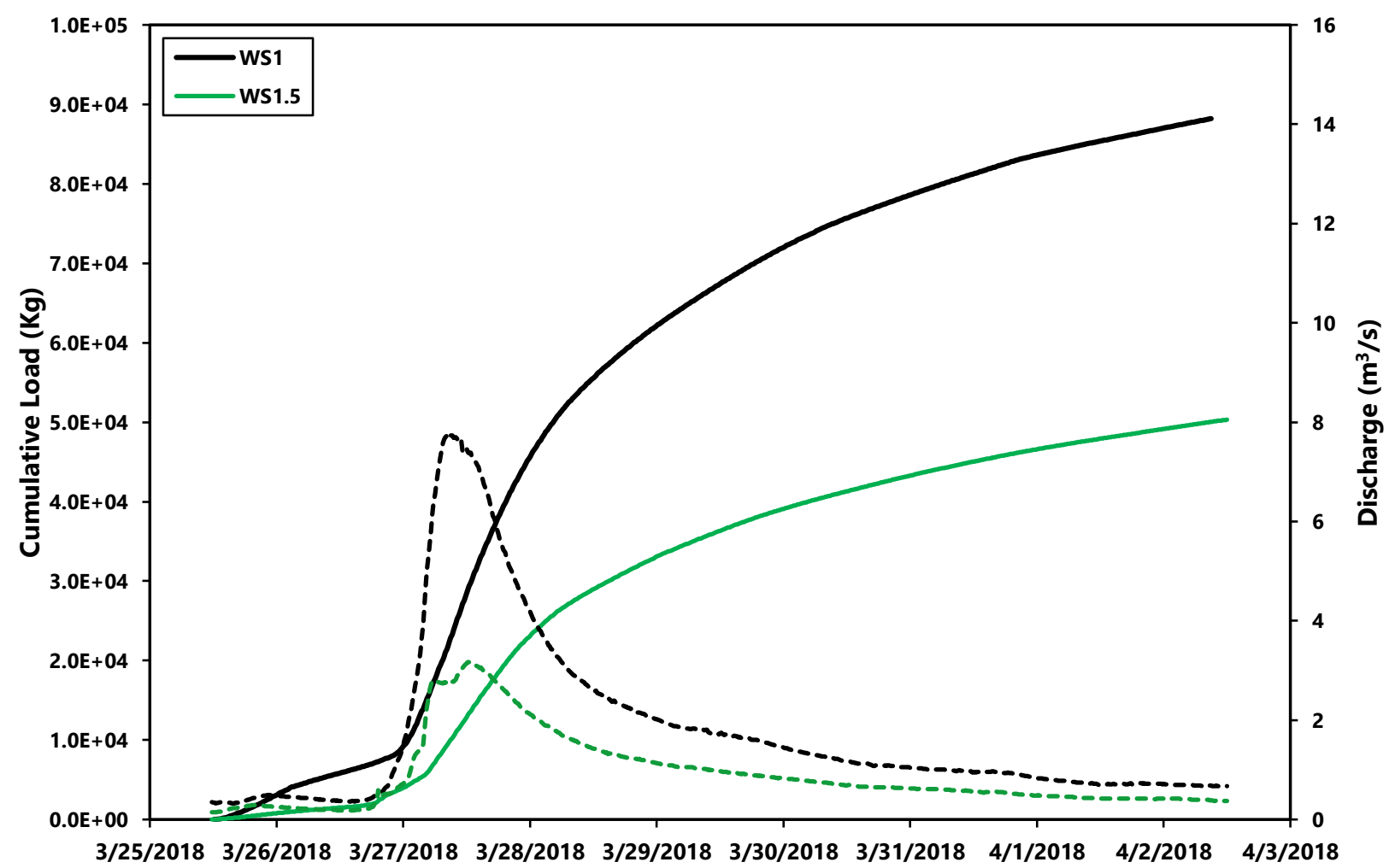

Figure 19. Cumulative load (solid line) and discharge (dashed line) for a spring storm at WS1 and WS1.5. 


\section{Seasonal Load}

Results showed a distinct $\mathrm{Cl}^{-}$loading difference between the seasons and seasonal storm events during the calculation period. Winter, spring, summer, and fall accounted for $42.1 \%, 34.9 \%$, $15.1 \%$, and $8.0 \%$ of the total cumulative $\mathrm{Cl}^{-}$load respectively (Fig.17A). Winter storms alone accounted for $29.1 \%$ of the total cumulative load and $50.6 \%$ of the total cumulative storm event load (Fig. 17A). Cumulative spring $\mathrm{Cl}^{-}$load contributes the next most to the total $\mathrm{Cl}^{-}$load at $34.9 \%$ (Fig.17A). Spring storm events accounted for $31.5 \%$ of total storm $\mathrm{Cl}^{-}$load and $18.1 \%$ of total $\mathrm{Cl}^{-}$ load. Summer and fall storm events accounted for a small portion of total $\mathrm{Cl}^{-}$load at $8.2 \%$ and $2.1 \%$ respectively (Fig. 17A). Regarding total storm event $\mathrm{Cl}^{-}$load, summer accounted for $14.3 \%$ and fall accounted for 3.6\% (Fig. 17A).

Results showed a more even distribution of flow volume over the seasons. Approximately a third of total discharge can be attributed to winter (33.0\%), spring (31.4\%), and summer (27.4\%) (Fig.18). Storm event discharge during every season except fall made up greater than half of total discharge during that season (Fig.17B). Winter storms accounted for $22.7 \%$ of the total discharge and $39.2 \%$ of discharge during storm events (Fig.17B). Spring storms made up $15.8 \%$ of the total discharge and $27.3 \%$ of total event flow (Fig. 17B). Summer storms accounted for $17.2 \%$ of the total discharge and $29.7 \%$ of the total event discharge (Fig. 17B). Percentages by discharge volume and $\mathrm{Cl}^{-}$load were close to equal during the fall (Fig. 17A/B). Winter and early spring events, although smaller in discharge magnitude than late spring and summer events, made up a comparable or much larger contribution (i.e. a greater step) to total cumulative $\mathrm{Cl}^{-}$load (Fig. 18).

$\mathrm{A} \mathrm{Cl}^{-}$flux vs discharge plot for WS1 storm event samples reveals a branching trend (Fig. 20). This pattern is best described when data are categorized by season. The base of the trend is made up of samples from all seasons (Fig. 20). The upper branch has the steepest slope and consists of only winter and spring samples (Fig. 20). The lower branch has a shallower slope the appears 
to reach an asymptote of $0.2 \mathrm{~kg} / \mathrm{s}$ around a discharge of $5 \mathrm{~m}^{3} / \mathrm{s}$. At discharges greater than $6.5 \mathrm{~m}^{3} / \mathrm{s}$ the lower branch consists of only summer samples while at lower discharges it includes samples from all the seasons. 


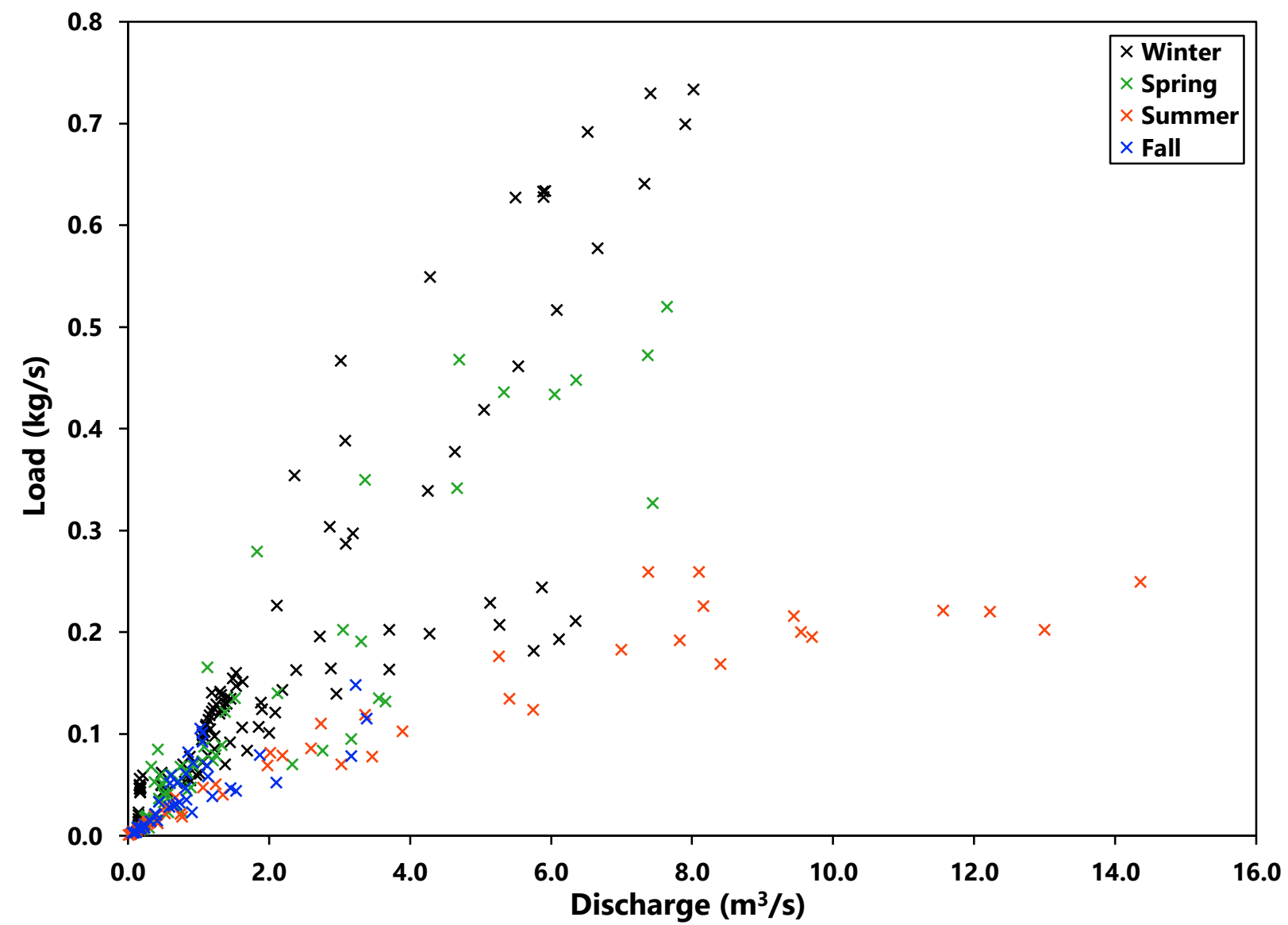

Figure 20. Plot of instantaneous $\mathrm{Cl}^{-}$flux vs. discharge at WS1 with data sorted by season. Data points represent only samples collected during storm events. 


\section{CHAPTER IV: DISCUSSION}

\section{Overview}

Statistically significant differences were observed in $\left[\mathrm{Cl}^{-}\right]:[\mathrm{X}]$ ratios between urban and agricultural waters. The hypothesis that ratios of $\mathrm{Cl}^{-}$are the same between urban and agricultural water with respect to the $\mathrm{Na}^{+}, \mathrm{Ca}^{2+}, \mathrm{Br}^{-}$, and $\mathrm{NO}_{3}-\mathrm{N}$ is rejected. The null hypothesis that urban and agricultural waters have different $\mathrm{Cl}^{-}$ratios was not rejected with respect to $\mathrm{K}^{+}$. Ratios of $\mathrm{Cl}^{-}$to $\mathrm{Na}^{+}, \mathrm{Br}^{-}$, and $\mathrm{NO}_{3}-\mathrm{N}$ indicate that road salt in the main source of $\mathrm{Cl}^{-}$is dominantly agricultural ELW.

Over the calculation period, $57.5 \%$ of total $\mathrm{Cl}^{-}$export occurred during storm events (Fig. 17A). Thus, it appears that storm event load is greater than non-event load. There appeared to be clear seasonal patterns in $\mathrm{Cl}^{-}$load. Seasonal event load calculations revealed that a disproportionate amount of $\mathrm{Cl}^{-}$was exported during winter and spring events $(82.1 \%)$ compared to summer and fall events (Fig. 17A). Winter and spring events also made up $47.2 \%$ of total $\mathrm{Cl}^{-}$load during the entire calculation period (Fig. 17A).

\section{Water Chemistry and Chloride Source}

Major ion concentrations of stream water (i.e. WS1, WS1.25, WS1.5) fall between those measured in tile drains and at WS2 for all six ions. This indicates that the mixing of these two waters generate the composition of water in SMC. Low flow and stagnant conditions in the stream that coincide with a loss of tile input in the late summer through most of the fall show that tile input is the main water source to SMC. Substantial difference exists between median ion concentrations in well and tile waters, except with respect to $\mathrm{K}^{+}$. Although the single well sampled in this study is unlikely representative of all ELW groundwater, it supports that SMC does not receive any substantial input from groundwater unimpacted by agriculture as stream waters are 
more similar to tile water than to well water. Groundwater and tile water should thus be considered compositionally different.

Waters that interact with urban areas in ELW appear to be the main source of $\mathrm{Cl}^{-}$and $\mathrm{Na}^{+}$ to SMC while tile waters act as the main source of $\mathrm{Ca}^{2+}$ and $\mathrm{NO}_{3}-\mathrm{N}$. Fertilizer applied to fields is the source of $\mathrm{NO}_{3}-\mathrm{N}$ while $\mathrm{Ca}^{2+}$ is both the result of weathering and cation exchange with soil as water flows to tiles and a byproduct of agricultural practices such as liming of fields (Kaushal et al., 2018; Kopáček et al., 2014). The data show $\mathrm{Cl}^{-}$concentrations decrease along SMC as tile inputs dilute higher $\mathrm{Cl}^{-}$concentration water exiting the headwaters of SMC. However, load calculations illustrate that $\mathrm{Cl}^{-}$export in SMC increases downstream, indicating that $\mathrm{SMC}$ receives significant $\mathrm{Cl}^{-}$input along its reach. This is consistent with a previous study in Little Kickapoo Creek, a low-order urban-agricultural stream in a similar watershed located $12 \mathrm{~km}$ south of ELW, which shows dilution of $\mathrm{Cl}^{-}$concentration but increased $\mathrm{Cl}^{-}$mass flux downstream Creek, (Peterson and Benning, 2013).

Ratios of $\mathrm{Cl}^{-}$to $\mathrm{Na}^{+}, \mathrm{Br}^{-}$, and $\mathrm{NO}_{3}-\mathrm{N}$ as well as seasonal trends in $\mathrm{Cl}^{-}$and $\mathrm{Na}^{+}$ concentrations indicate road salt as the main $\mathrm{Cl}^{-}$source for SMC. The molar ratio of $\mathrm{Na}^{+}$to $\mathrm{Cl}^{-}$ (Fig. 12) in water where $\mathrm{NaCl}$ is the main $\mathrm{Cl}^{-}$source has a value at or close to 1 . Waters impacted by deicing salt where $\mathrm{NaCl}$ was the deicing agent would thus have a ratio close to 1 (Lax et al., 2017). Most ELW samples have excess $\mathrm{Cl}^{-}$compared to $\mathrm{Na}^{+}$(Fig. 12), but the ratio is still close to one except for several tile water samples and summer stream samples. This "excess" $\mathrm{Cl}^{-}$is likely due to $\mathrm{Na}^{+}$removal by cation exchange (Kaushal et al., 2018; Cooper et al., 2014) and extra $\mathrm{Cl}^{-}$ from the $32 \% \mathrm{CaCl}_{2}$ solution that road salt is pre-treated with in McLean County before application (Stokes, Personal Communication). 
Seasonal trends in $\left[\mathrm{Cl}^{-}\right]:\left[\mathrm{Br}^{-}\right]$ratios support road salt as the main $\mathrm{Cl}^{-}$source in ELW (Fig. 4). The domains on the plot of $\left[\mathrm{Cl}^{-}\right]:\left[\mathrm{Br}^{-}\right]$ratios vs $\mathrm{Cl}^{-}$concentrations (Fig. 4) used to identify $\mathrm{Cl}^{-}$ sources were defined in a previous study using water samples primarily collected in Illinois (Panno et al., 2006a). Winter and early spring samples plot more towards the sample of road salt runoff reflecting the flushing of road salt through SMC. In contrast, by late spring the majority of road salt runoff has moved through SMC allowing stream $\mathrm{Cl}^{-}$concentrations to return to more normal levels reflecting the $\mathrm{Cl}^{-}$concertation in tiles rather than urban runoff. Consequently, late spring, summer, and fall samples plot closer to the field tile domain. Only one tile sample plots in the appropriate domain for field tiles, while most of the rest exhibit elevated $\mathrm{Cl}^{-}$consistent with the influence of road salt or septic effluent.

Vectors on $\mathrm{Cl}^{-}$vs $\mathrm{NO}_{3}-\mathrm{N}$ plots (Fig. 13) are based on relations described in Angel and Peterson (2015) and Böhkle (2002) can be used to identify the influence of various anthropogenic sources of $\mathrm{NO}_{3}-\mathrm{N}$ and $\mathrm{Cl}^{-}$on a water. This graph can also be used to illustrate where a set of samples plot in relation to both $\mathrm{NO}_{3}-\mathrm{N}$ and $\mathrm{Cl}^{-}$background thresholds concentration. Excluding the 5 well samples, only 7 tile samples, 5 of which were from the T3 site, and 3 stream samples from WS1 had $\mathrm{Cl}^{-}$levels below the background threshold of $18 \mathrm{mg} / \mathrm{l}$. In contrast, many stream samples and several tile samples had $\mathrm{NO}_{3}-\mathrm{N}$ concentrations below the background threshold of $2.5 \mathrm{mg} / \mathrm{l}$. Samples from all seasons, particularly those collected in the winter and fall, show clear road salt influence, but a number of these samples have an elevated nitrate concentration shifting them away from the road salt vector to the animal waste and septic effluent vector.

The animal waste and septic effluent vector is not suitable for ELW; thus, this area represents a mixed water signal. Animal waste use is minimal in ELW (Ruffatti, 2019; Evergreen Lake Watershed Planning Committee, 2006) and can be ruled out as a $\mathrm{Cl}^{-}$source. Sewage or septic 
effluent is unlikely to make a large contribution to the elevated $\mathrm{Cl}^{-}$levels observed in SMC and tile water due to the low density of houses and lack of a wastewater treatment plant in ELW. The village of Hudson could be a significant source of $\mathrm{Cl}^{-}$derived from septic effluent, but the signature and contribution from these systems would be overshadowed by that from road salt used in Hudson and along Interstate 39. This is consistent with a study conducted in New York that found sewage

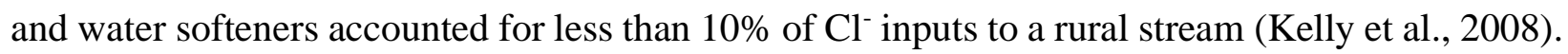
Samples plot along the animal waste and septic effluent vector (Fig. 13) because the influence of tile discharge and road salt overlap to elevate both $\mathrm{NO}_{3}-\mathrm{N}$ and $\mathrm{Cl}^{-}$making samples appear to be influenced by septic effluent or animal waste. The vector for classifying waters as impacted by animal waste or septic effluent defined on a $\mathrm{Cl}^{-}$vs $\mathrm{NO}_{3}-\mathrm{N}$ plot may need to be reconsidered in systems simultaneously impacted by road salt and $\mathrm{N}$ fertilizers.

After most road salt was flushed from surfaces during late winter and early spring in the ELW, tile drains still provided most of the non-event flow water to SMC until mid-July. Stream chemistry reflect this as waters plot along the fertilizer vector (Fig. 13A) and fall away from the 1:1 $\left[\mathrm{Cl}^{-}\right]:\left[\mathrm{Na}^{+}\right]$line (Fig. 12). Tile input stopped in the late summer through most of the fall where low flow and stagnant conditions persisted. During low flow conditions most water in the stream was groundwater inflow and overland flow from storm events. Multiple studies support subsurface retention of $\mathrm{Cl}^{-}$and $\mathrm{Na}^{+}$associated with road salt runoff in soil and groundwater near impacted streams, retention ponds, and roads (Hubbard et al. 2017; Ledford et al., 2016; Casey et al., 2013; Kelly et al., 2008). Retained $\mathrm{Cl}^{-}$then serves as a source to the stream after the late spring, summer, and fall (Ludwikowski, 2016). Groundwater entering SMC during the fall reflects legacy road salt contamination, with storm events acting to dilute impacted groundwater flushing it from the 
subsurface. When tile flow resumes in the late fall, water composition moves back toward the $\mathrm{N}$ fertilizer vector and exhibits more drift from the $\left[\mathrm{Cl}^{-}\right]:\left[\mathrm{Na}^{+}\right] 1: 1$ line.

Legacy road salt contamination was observed during weekly samplings at WS2 in the late summer and fall. Groundwater discharging into the stream just below the stormwater pond outlet forming a flowing pool that persisted for the entire dry season had elevated $\mathrm{Cl}^{-}$and $\mathrm{Na}^{+}$ concentrations (Figs. 6 and 10) with $\left[\mathrm{Cl}^{-}\right]:\left[\mathrm{Na}^{+}\right]$ratios close to 1 (Fig. 12), which is indicative of road salt contamination, and $\left[\mathrm{Cl}^{-}\right]:\left[\mathrm{NO}_{3}-\mathrm{N}\right]$ ratios that plot along the road salt vector (Fig. 13). During these periods of base flow, evaporation likely plays a role in the elevated concentration of ions during the late summer and fall but would not impact ratios.

Seasonal patterns in the $\mathrm{Cl}^{-}$load support road salt being the main source of $\mathrm{Cl}^{-}$in ELW. December through March in ELW accounts for $63 \%$ of the total chloride load. A study conducted in the $230 \mathrm{~km}^{2}$ Hinkson Creek Watershed (HCW), a multi land use watershed (34\% forest, 38\% agriculture, 25\% urban) located in Missouri, calculated that on average ( $n=3.5$ years) December through March account for $64 \%$ of total $\mathrm{Cl}^{-}$export (Hubbart et al., 2016). In both cases approximately two-thirds of $\mathrm{Cl}^{-}$export occurs during the third of the year when road salt would be applied and is flushed from surfaces through the watershed, illustrating its role as a principal $\mathrm{Cl}^{-}$ source. This result is somewhat surprising given the difference in percentage urban/impervious cover and watershed area between ELW (10\% and $\left.106.4 \mathrm{~km}^{2}\right)$ and HCW but could be attributed to differences in the severity and frequency of events requiring road deicing between studies as well as different salt application rates.

While road salt is a major $\mathrm{Cl}^{-}$source in ELW, the contribution of $\mathrm{KCl}$ fertilizer cannot be ignored. Concentrations of Cl- were reported to rise from 5-10 mg/l to $25-30 \mathrm{mg} / \mathrm{l}$ in tiles draining a corn plot in Illinois following $\mathrm{KCl}$ treatment (David et al., 2016). A second study reported $\left[\mathrm{Cl}^{-}\right.$ 
]:[ $\left.\mathrm{Na}^{+}\right]$ratios between 2.2 and 2.9 and above background $\mathrm{Cl}^{-}$concentrations between 36 and 95 $\mathrm{mg} / \mathrm{l}$ in tile-drain waters thought to be impacted by $\mathrm{KCl}$ fertilizer (Lax et al., 2017). The median $\left[\mathrm{Cl}^{-}\right]:\left[\mathrm{Na}^{+}\right]$ratio of 1.61 (Table 2 ) in tile-drain waters during this study is not consistent with the reported values (Lax et al., 2017). Ratios of $\left[\mathrm{Cl}^{-}\right]$: $\left[\mathrm{Na}^{+}\right]$ranged from 7.74 to 0.58 (Table 2) in tile waters with only a minority of tile water samples ( 8 of 64 ) exhibiting a ratio within the range reported for $\mathrm{KCl}$ influence. The median $\mathrm{Cl}^{-}$concentration in sampled tiles $(49.05 \mathrm{mg} / \mathrm{l})$ is consistent with $\mathrm{Cl}^{-}$concentrations reported in the literature for $\mathrm{KCl}$ impacted tile waters. The only tiles that always exhibited $\mathrm{Cl}^{-}$concentrations consistent with $\mathrm{KCl}$ influence were the ones sampled at WS1 and WS2.

The $\left[\mathrm{Cl}^{-}\right]:\left[\mathrm{K}^{+}\right]$ratio plot (Fig. 15 ) did not identify the presence of $\mathrm{KCl}$ using the same principal as $\left[\mathrm{Cl}^{-}\right]:\left[\mathrm{Na}^{+}\right]$ratio plots. This is probably due to where and why these salts are applied. $\mathrm{KCl}$ is applied to fields where crops take up the $\mathrm{K}^{+}$as a nutrient and free $\mathrm{K}^{+}$can interact more with soil particles allowing it to adsorb and become less mobile than the conservative $\mathrm{Cl}^{-}$left behind (Ávila et al., 1992). Storm events appear to mobilize $\mathrm{K}^{+}$as spikes in concentration occur in all sampled waters during events. The behavior of $\mathrm{K}^{+}$during storm events contrasts with $\mathrm{Ca}^{2+}$ and $\mathrm{NO}_{3}-\mathrm{N}$, which are initially diluted in tile and stream water during storm events, although $\mathrm{NO}_{3}-\mathrm{N}$ concertation increases in the stream after the dilution. This indicates that $\mathrm{K}^{+}$is also mobilized from a source within the stream channel and in the urban headwaters while $\mathrm{NO}_{3}-\mathrm{N}$ is only mobilized from fields after a lag between precipitation and increase tile discharge to SMC. A similar $\mathrm{K}^{+}$ dynamic was observed in a study of storm solute behavior in a montane Mediterranean watershed where Low baseflow concentrations were attributed to biologic uptake, cation exchange, and fixation into clay lattices (Ávila et al., 1992). Spikes in $\mathrm{K}^{+}$concentration during storm events were 
the result of leaching of $\mathrm{K}^{+}$from surfaces, organic soil layers, and flushing of subsurface accumulation (Ávila et al., 1992).

Moderately elevated $\mathrm{Cl}^{-}$concentrations and $\left[\mathrm{Cl}^{-}\right]:\left[\mathrm{Na}^{+}\right]$ratios much greater than 1 , and in field tiles along with widespread use in Illinois support some contribution of $\mathrm{Cl}^{-}$from $\mathrm{KCl}$ fertilizer. Tile drains where these chemical traits were not observed were likely draining fields where $\mathrm{KCl}$ was not applied during the study period. In tiled watersheds, elevated $\mathrm{Cl}^{-}$from $\mathrm{KCl}$ fertilizer has been shown to move rapidly from the shallow surface to streams with concentrations returning to pre-application levels within 1-2 years (David et al., 2016). Due to the irregular nature of $\mathrm{KCl}$ application, the amount of fertilizer derived $\mathrm{Cl}^{-}$discharged to $\mathrm{SMC}$ would vary from year to year. Both road salt and $\mathrm{KCl}$ fertilizer are important $\mathrm{Cl}^{-}$sources to $\mathrm{SMC}$ and contribute to above background $\mathrm{Cl}^{-}$concentrations observed in ELW, but data support road salt as the main $\mathrm{Cl}^{-}$ contributor. Fertilizer derived $\mathrm{Cl}^{-}$was unable to elevate $\mathrm{Cl}^{-}$level above the EPA chronic and acute limits, whereas road salt was able to raise $\mathrm{Cl}^{-}$levels above the chronic limit in ELW for short periods of time. The $\mathrm{Cl}^{-}$from tile waters plays a part in the 'excess' $\mathrm{Cl}^{-}$that causes the $\left[\mathrm{Cl}^{-}\right]:\left[\mathrm{Na}^{+}\right]$ to be slightly greater than 1 .

$\mathrm{KCl}$ can explain moderately elevated $\mathrm{Cl}^{-}$concentrations in tile waters but cannot account for the highly elevated concentrations (>100 mg/l). Chemical data suggest the tiles where high $\mathrm{Cl}^{-}$ concentrations were observed were impacted by road salt runoff, which could mask the smaller $\mathrm{KCl}$ signature. In the winter and spring, the tile drains at WS1.25 and T1 in the adjacent watershed exhibited high $\mathrm{Cl}^{-}$concentrations and $\left[\mathrm{Cl}^{-}\right]:\left[\mathrm{Na}^{+}\right]$ratios close to 1 . The WS1.25 tile discharges into SMC next to a main road that connects Hudson to Normal and receives deicing treatment in the winter. The tile in the adjacent watershed also discharges near a road and is in an area near Interstate 55, which is likely to be contaminated by road salt. Elevated $\mathrm{Cl}^{-}$in $\mathrm{T} 1$ and the WS1.25 
tile drain is the result of road salt runoff infiltrating and draining through the tile to SMC. Drainage from tiles may act to reduce salt build up in the subsurface near roads and enhance flushing by storm events (Lax and Peterson, 2009).

Nitrification inhibitors are another potential source of agricultural $\mathrm{Cl}^{-}$. Their contribution, however, is unlikely to be significant or noticeable when compared to road salt and $\mathrm{KCl}$ inputs. The $\mathrm{Cl}^{-}$originating from nitrification inhibitors is also not readily mobile as only minimal dehalogenation occurs after the inhibitor byproduct is taken up by the crops (Meikle and Redemann, 1966). Further, the byproducts are organic $\mathrm{Cl}^{-}$(Meikle and Redemann, 1966), which is thought to be more easily retained in soils (Kopáček et al., 2014).

Pristine groundwater and the signature of road salt in only select tile drains near roads highlights the limited extent of road salt contamination in a low urban land use watershed like ELW. That is, contamination is only present in streams receiving road salt runoff and in the near vicinity of salted roads. The rest of the watershed may remain relatively unaffected by road salt application. Even in streams receiving road salt runoff, stretches between salted roads or far from developed areas may remain relatively unimpacted, which was also observed in a coupled groundwater-solute transport model for a shallow aquifer model in central Illinois (Ludwikowski, 2016). Year-round baseflow $\mathrm{Cl}^{-}$concentrations of $200-230 \mathrm{mg} / \mathrm{l}$ were reported in a study of a watershed with $44 \%$ urban land use (Stripe et al., 2017). ELW (10\% urban/impervious coverage) had $\mathrm{Cl}^{-}$concentration from ground and tile waters, excluding tiles contaminated road salt runoff in the winter, that ranged from 1 to $95 \mathrm{mg} / \mathrm{l}$. Previous studies have highlighted the importance of the location of urban areas in low urban land use watersheds as a controlling factor on $\mathrm{Cl}^{-}$ concentrations in the watershed streams (Lax et al., 2017; Ludwikowski, 2016). Along SMC, urban zones are located in its headwaters, and its lower reach near WS1 flows along Interstate 39 and the 
western edge of the village of Hudson. Thus, salting on this low percentage of area in ELW can greatly influence the $\mathrm{Cl}^{-}$dynamic in SMC, while drainages and groundwater away from SMC, and therefore the main $\mathrm{Cl}^{-}$sources, remain relatively unimpacted unlike in a watershed with higher urban percentage urbanization (Stripe et al., 2017).

Although the $\mathrm{Cl}^{-}$concentration in SMC and tile waters did not exceed the EPA chronic limit for significant periods of time and never exceeded the acute limit, $\mathrm{Cl}^{-}$concentrations at or above $100 \mathrm{mg} / \mathrm{l}$ were observed at WS2 for periods of days to weeks (Fig. 6). Alteration of microbial communities begin to manifest at this $\mathrm{Cl}^{-}$concentration (Kaushal et al., 2005). Fluctuations in $\mathrm{Na}^{+}$ concentration between weekly samplings (10-30 mg/l) at all stream stations in SMC (Fig. 10) greatly exceeded the 3 to $14 \mathrm{mg} / \mathrm{l}$ linked to osmoregulatory stress in aquatic biota (Tyree et al., 2017). Chemical data show that salting in a watershed with low urban land-use can create in-stream conditions with the potential to alter or harm stream ecosystems.

\section{Impact of Storm Events on Chloride Load and Concentration}

Storms play an important role in $\mathrm{Cl}^{-}$export in ELW. The load calculation period was approximately 336.5 days, with event flow making up approximately 64.3 days or $19.1 \%$ of that period. Thus, $57.5 \%$ of $\mathrm{Cl}^{-}$load and $58.0 \%$ of flow volume occurred during $19.1 \%$ of the calculation period. Storms are particularly important to load during the winter, where they accounted for almost $1 / 3$ of total $\mathrm{Cl}^{-}$load and $1 / 2$ of total storm event load. Winter and spring combined account for $80 \%$ of event $\mathrm{Cl}^{-}$load and almost half of total $\mathrm{Cl}^{-}$load.

The impact of storm events on stream $\mathrm{Cl}^{-}$concentration varies based on season (Fig. 21). Winter and early spring storm events result in large spikes in $\mathrm{Cl}^{-}$concentrations after a brief initial dilution illustrating the role of storms in flushing salt from impervious surfaces and the shallow 
subsurface. Once salt has been flushed, storm runoff dilutes $\mathrm{Cl}^{-}$concentrations, but the rate of export still increases as a result of increased discharge (Fig. 18 and 21). The first major storm event after the summer dry season in late September also resulted in a smaller scale increase in $\mathrm{Cl}^{-}$ concertation and represents a second flushing event. The subsequent storm in October saw a return to dilution by storm events (Fig. 21). Variable $\mathrm{Cl}^{-}$concentration dynamics during storm events in ELW highlights the need for high-frequency sampling regimes to make accurate load estimates.

A similar flushing dynamic was seen in an urban-fringe watershed located in southern California after the dry season, where the first storm resulted in a $\mathrm{Cl}^{-}$concentration spike with following storms causing dilution (Kinoshita et al., 2014). The initial dry season $\mathrm{Cl}^{-}$spike was attributed to the flushing of salt that built up in the basin by atmospheric deposition and agricultural activity. In watersheds where road salt is applied there are two periods of flushing instead of one. The initial storm following a dry period may also mobilize road salt trapped in the subsurface near salted roads and the interstates as well as that concentrated by evaporation. In both cases, storm events are important in preventing $\mathrm{Cl}^{-}$build-up on watershed surfaces.

The magnitude of a storm event, as defined by peak discharge, appears to have a different impact of $\mathrm{Cl}^{-}$export depending season (Fig. 20). Increased discharge during winter and spring storm events generates more $\mathrm{Cl}^{-}$export than events with similar or larger peak discharges generate during the summer or fall. A closer examination of the lower branch reveals that the pattern cannot fully be explained as seasonal behavior because, while it is mostly made up of summer and fall water samples, it also contains samples from the winter and spring. The steep upper branch, which only contains samples from the winter and spring, more likely represent the period when road salts are being flushed through SMC, while the lower branch represents the $\mathrm{Cl}^{-}$load-discharge relationship after road salt is flushed from watershed surfaces. 
The lower branch of the discharge-flux relationship (Fig. 20) appears to reach an asymptote. The quasi-stable flux of $0.2 \mathrm{~kg} / \mathrm{s}$ at higher discharges along the lower branch highlights the lack of available $\mathrm{Cl}^{-}$on the surface during storm events. Storms would increase $\mathrm{Cl}^{-}$load in three ways: flushing from watershed surfaces, increased tile flow (i.e. flushing of the near subsurface), and wet deposition. Surficial flushing is minimal after winter until the first storm following a prolonged dry period as not enough time has passed to allow significant $\mathrm{Cl}^{-}$build up on surfaces. Thus, the asymptotic behavior implies that wet deposition and tile discharge reach a constant mass flux into SMC regardless of storm intensity. Asymptotic behavior in the dischargeflux relationship was also observed for spring and summer (April - August) storms at $0.1 \mathrm{~kg} / \mathrm{s}$ in the Casperkill watershed $\left(31 \mathrm{~km}^{2}\right.$ and $44 \%$ urban) in New York (Stripe et al., 2017). Similar behavior in ELW indicates that the percentage urban land use and watershed area may not impact the behavior of $\mathrm{Cl}^{-}$flushing.

Asymptotic behavior is attributed to the relative contribution to stream stormflow from surface runoff increasing during more intense precipitation events while the contribution from increased baseflow due to infiltration remains static once soil become saturated (Stripe et al., 2017). A static contribution from baseflow is important because this water contains high $\mathrm{Cl}^{-}$ concentrations from legacy road salt and $\mathrm{KCl}$ fertilizers. This conclusion supports the upper branch (Fig. 20) being related to the presence of road salts rather than being purely seasonal. Interestingly, the presences of tile drains, which expedite the movement of infiltration to streams, do not prevent this asymptotic behavior. Instead tile drains may only shift the occurrence of the asymptote out to a higher discharge or facilitate the flushing of $\mathrm{Cl}^{-}$from only the soil above the drain while preventing or slowing flushing of deeper soil. 


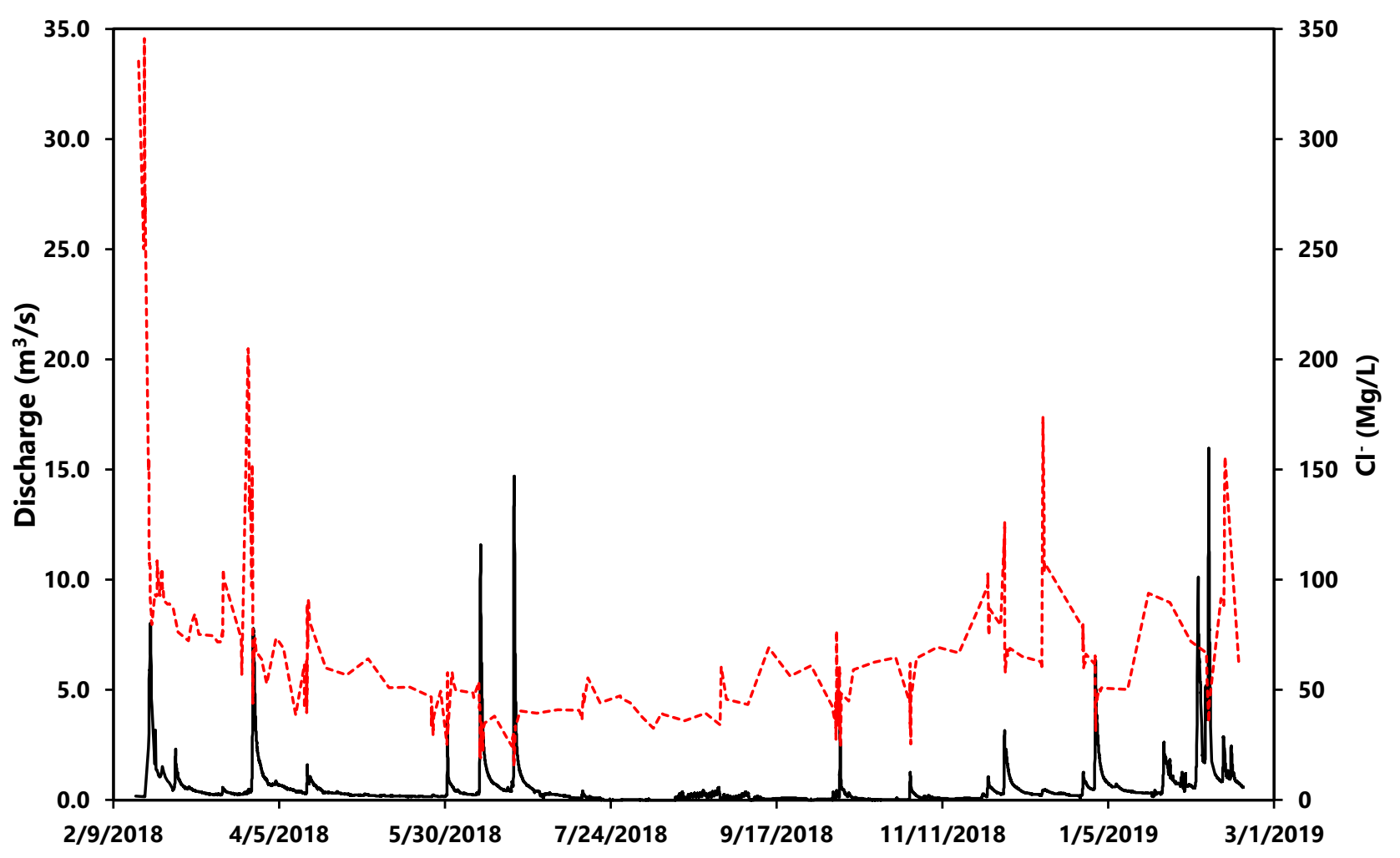

Figure 21. Combination Cl- concentration (dashed red) and hydrograph (black) at WS1. 


\section{CHAPTER V: CONCLUSIONS}

Storm events are vital in flushing $\mathrm{Cl}^{-}$from ELW, a low order urban-agricultural watershed. Results imply two periods of $\mathrm{Cl}^{-}$flushing in ELW. The first is associated with flushing of road salt from impervious surfaces following the cold season and second is associated with flushing salt build up from the dry season (Ávila et al., 1992). Some of this second flush is likely associated with legacy road salt contamination. Similar $\mathrm{Cl}^{-}$flushing behavior in a larger watershed with high urban land use may indicate that watershed area and urban land use do not impact the behavior of $\mathrm{Cl}^{-}$flushing.

There are two relationships between $\mathrm{Cl}^{-}$flux and discharge. When road salt is present on watershed surfaces, increased discharge always corresponds with an increased $\mathrm{Cl}^{-}$flux. During storm events when road salt is not present on watershed surfaces, the discharge-flux relationships reaches an asymptote. That is, there is a point where a further increase in stream discharge will not result in higher the $\mathrm{Cl}^{-}$flux. The enhanced subsurface drainage provided by tile drains in ELW does not prevent the asymptotic behavior of the $\mathrm{Cl}^{-}$flux-discharge relationship.

Overall, urban, tile, and stream waters exhibit some degree of salinization in ELW with respect to $\mathrm{Cl}^{-}$as almost all sample concentrations were elevated above the background threshold concentration. Data support road salt as main source of $\mathrm{Cl}^{-}$, which contradicts a previous study in two rural Illinois watersheds that identifies fertilizers as the main $\mathrm{Cl}^{-}$source (David et al., 2016) but confirms the findings of a study in a rural New York watershed that identified road salt as the main $\mathrm{Cl}^{-}$source (Kelly et al., 2008). The discrepancy in dominant $\mathrm{Cl}^{-}$source is probably the result of differences in road salt and fertilizer input between watersheds that stem from road salt application rates, fertilizer treatment schedules, and local weather conditions. 
These results highlight the dramatic influence that deicing operations on only a small portion of a watershed can have on the $\mathrm{Cl}^{-}$dynamics of the entire system. Road salt appears to be able to salinize the dominantly agricultural ELW raising $\mathrm{Cl}^{-}$concentrations to levels hazardous to ecosystems and water supplies (>100 mg/l), although the exact extent of salinization in ELW remains unknown and is likely confined to surface and ground water in areas where deicing operations occur and that receive road salt runoff. Fertilizer inputs should also not be ignored as this work and others (David et al., 2016; Kopáček et al. 2014) show that fertilizers have the potential to be an important contributor to salinization in northern regions that warrants further study. Due to the storage of $\mathrm{Cl}^{-}$in the subsurface (David et al., 2016; Kopáček et al. 2014, Kelly et al., 2008), even small salt inputs in northern agricultural watersheds can induce salinization at a level that could take years to return to background (Ludwikowski, 2016) and that could have far reaching ecologic and water quality impacts. 


\section{REFERENCES}

Angel, J. and Peterson, E., 2015, Nitrates in Karst systems: comparing impacted systems to a relatively unimpacted system: Journal of Geography and Geology, v. 7, no. 1, p. 65-76, doi 10.5539/jgg.v7n1p65.f

Ávila, A, Piñol, J., Rodá, F., and Neal., C., 1992, Storm Solute behavior in a montane Mediterranean forested catchment: Journal of Hydrology, v 140, no. 1-4, p. 143-161, doi 10.1016/0022-1694(92)90238-Q.

Böhlke, J.K., 2002, Groundwater recharge and agricultural contamination: Hydrogeology Journal, v. 10, no. 1, p. 153-179, doi 10.1007/s10040-002-0210-z.

Cañedo-Argüelles, M., Sala, M., Peixoto, G., Prat, N., Faria, M., Soares, A.M.V.M., Barata, C., and Kefford, B., 2016, Can salinity trigger cascade effects on streams? A mesocosm approach: Science of the Total Environment, v. 540, no. 1, p. 3-10, doi 10.1016/j.scitotenv.2015.03.039.

Cañedo-Argüelles, M., Kefford, B., Piscart, C., Prat, N., Schäfer, R.B., and Schulz, C.J., 2013, Salinization of rivers: An urgent ecological issue: Environmental Pollution, v. 173, no. 1, p. 157-167, doi 10.1016/j.envpol.2012.10.011.

Casey, R.E., Lev, S.M., and Snodgrass, J.W., 2013, Stormwater ponds as a source of long-term surface and groundwater salinization: Urban Water Journal, v. 10, no. 3, p. 145-153, doi 10.1080/1573062X.2012.716070.

Cooper, C.A., Mayer, P.M., and Faulkner, B.R., 2014, Effects of road salts on groundwater and surface water dynamics of sodium and chloride in an urban restored stream: Biogeochemistry, v. 121, no. 1, p. 149-166, doi 10.1007/s10533-014-9968-z. 
David, M, Mitchell, C., Gentry, L., and Salemme, R., 2016, Chloride Sources and Losses in Two Tile-Drained Agricultural Watersheds: Journal of Environmental Quality, v. 45, no. 2, p. 341-348, doi 10.2134/jeq2015.06.0302.

Dugan, H., Bartlett, S., Burke, S., Doubek, J., Krivak-Tetley, F., Skaff, N., Summers, J., Farrell, K., McCullough, I., Morales-Williams, A., Roberts, D., Ouyan, Z., Scordo, F., Hanson, P., and Weathers, K., 2017, Salting our freshwater lakes: Proceedings of the National Academy of Sciences of the United States of America, v. 114, no. 17, p. 4453-4458, 10.1073/pnas.1620211114.

Edwards, M., and Triantafyllidou, S., 2007, Chloride-to-sulfate mass ratio and lead leaching to water: American Water Works Association, v. 99, no. 7, p. 96-109, doi N/A.

Evergreen Lake Watershed Planning Committee, 2006, Evergreen Lake Watershed Plan, https://web.extension.illinois.edu/lmw/downloads/22857.pdf, accessed on December 03 2017.

Gutchess, K., Jin, L., Lautz, L., Shaw, S.B., Zhou, X., and Lu, Z., 2016, Chloride sources in urban and rural headwater catchments, central New York: Science of Total Environment, v. 565, p. 462-472, doi 10.1016/j.scitotenv.2016.04.181.

Herlihy, A., Stoddard, J., and Johnson, C., 1998, The Relationship Between Stream Chemistry and Watershed Land Cover Data in the Mid-Atlantic Region, U.S.: Water, Air, and Soil Pollution, v. 105, no. 1-2, p. 377-386, doi 10.1023/A:1005028803682.

Hubbart, J.A., Kellner, E., Hooper, L.W., and Zeiger, S., 2017, Quantifying loading, toxic concentrations, and systemic persistence of chloride in a contemporary mixed-land-use watershed using an experimental watershed approach: Science of the Total Environment, v. 581-582, no. 1, p. 822-832, doi 10.1016/j.scitotenv.2017.01.019. 
Hwang, H., Panno, S., and Hackley, K., 2015, Sources and Changes in Groundwater Quality with Increasing Urbanization, Northeastern Illinois: Environment \& Engineering Geoscience, v. 21, no. 2, p. 75-90, doi 10.2113/gseegeosci.21.2.75.

Illinois Environmental Protection Agency, 2006, Evergreen Lake Watershed TMDL Report, http://www.epa.illinois.gov/Assets/iepa/water-quality/watershed-management/tmdls/rep orts /evergreen-1 ake/ap proved-report.pdf, Accessed on December 032017.

Illinois State Geological Survey Staff, 2005, Quaternary deposits: Illinois State Geological Survey, ISGS $8.5 \times 11$ map series.

Jackson, R. and Jobbágy, E., 2005, From icy roads to salty streams: Proceeding of the National Academy of Science, v. 102, no. 41, p. 14487-14488, doi 10.1073/pnas.0507389102.

Kaushal, S.S., Likens., G.E., Pace, M.L., Haq, S., Wood, K.L., Galella, J.G., Morel, C., Doody, T.R., Wessel, B., Kortelainen, P., Räike, A., Skinner, V., Utz, R., and Jaworski, N., 2018, Novel 'chemical cocktails' in inland waters are a consequence of the freshwater salinization syndrome: Philosophical Transactions of the Royal Society B, v. 374, no. 1764, p. 1-11, doi 10.1098/rstb.2018.0017.

Kaushal S.S., Groffman P.M., Likens G.E., Belt K.T., Stack, W.P., Kelly, V.R., Band, L.E., and Fisher, G.T., 2005, Increased salinization of fresh water in the northeastern United States: Proceeding of the National Academy of Sciences of the United States of America, v.102, no. 38 , p. $13517-13520$, doi 10.1073/pnas.0506414102.

Kelly, W.R., Panno, S.V., Hackley, K.C., Hwang, H., and Martinsek, M.M., 2010, Using chloride and other ions to trace sewage and road salt in the Illinois Waterway: Applied Geochemistry, v. 25, no. 5, p. 661-673, doi 10.1016/j.apgeochem.2010.01.020. 
Kelly, V., Lovett, G., Weathers, K., Findlay, S., Strayer, D., Burns, D., and Likens, G., 2008, Long-Term Sodium Chloride Retention in a Rural Watershed: Legacy Effects of Road Salt on Streamwater Concentration: Environmental Science \& Technology, v. 42, no. 2, p. 410-415, doi 10.1021/es0713911.

Kinoshita, A.M., Hogue, T.S., Barco, J., and Wessel, C., 2014, Chemical flushing from an urbanfringe watershed: hydrologic and riparian soil dynamics: Environment Earth Sciences: v. 72, no. 3, p. 879-889, doi 10.1007/s12665-013-3011-x.

Kopáček, J., Hejzlar, J., Porcal, P., and Posch, M., 2014, A mass-balance study of chloride fluxes in a large central European catchment during 1900-2010L Biogeochemistry, v. 120, no. 1-3, p. 319-335, doi 10.1007/s10533-014-0002-2.

Lampo, L., 2017, Dynamics of Nitrate, Phosphorus, and Suspended Sediment Transport in Two Agricultural Streams in Central Illinois [M.S. thesis]: Illinois State University, 164 p.

Lax, S.M., Peterson, E.W., and Van der Hoven S.J., 2017, Stream chloride concentrations as a function of land use: a comparison of agricultural watershed to an urban agricultural watershed: Environmental Earth Sciences, v. 76, no. 708, p. 1-12, doi 10.1007/s12665017-7059-x.

Lax, S.M. and Peterson, E., 2009, Characterization of chloride transport in the unsaturated zone near salted road: Environmental Geology, v. 58, no. 5, p. 1041-1049, doi 10.1007/s00254008-1584-6.

Ledford, S.H, Lautz, L.K., and Stella J.C., 2016, Hyrdrogeologic Processes Impacting Storage, Fate, and Transport of Chloride from Road Salt in Urban Riparian Aquifers: Environmental Science \& Technology, v. 50, no. 10, p. 4979-4988, doi 10.10 21/acs.est.6b00402. 
Lilek, J., American Geosciences Institute, 2017, Roadway deicing in the United States, Factsheet 2017-003, https://www.americangeosciences.org/sites/default/files/CI_Factsheet_2017_ 3_Deicing_170712.pdf (accessed May 2019).

Ludwikowski, J.J., 2016, The Transport and Fate of Chloride within the Groundwater if a Mixed Urban Agricultural Watershed [M.S. thesis]: Illinois State University, 67 p.

McLean, M.M., Kelly M.D., and Riggs M.H., 1997, Thickness of Quaternary Deposits in McLean County, Illinois: Illinois State Geologic Survey, Scale 1:500,000, 1 sheet.

Meikle R.W. and Redemann C.T., 1966, Tracer Study of 6-Chloropicolinic Acid in Corn: Journal of Agricultural and Food Chemistry, v. 14, no. 2, p. 159-161, doi 10.1021/jf60144a018.

Nelson, S.S., Yonge, D.R., and Barber M.E., 2009, Effects of Road Salts on Heavy Metal Mobility in Two Eastern Washington Soils: Journal of Environmental Engineering, v. 135, no. 7, p. 505-510, doi https://doi.org/10.1061/(ASCE)0733-9372(2009)135:7(505).

Norrström, A.C., and Bergstedy, E., 2001, The impact of road de-icing salts $(\mathrm{NaCl})$ on colloid dispersion and base cations pools in roadside soils: Water, Air, and Soil Pollution, v. 127, no. 1-4, p. 281-299, doi 10.1023/A:1005221314856.

Panno, S., Hackley, K., Greenberg, S., Krapac, I., Landsberger, S., and O'Kelly, D., 2006a, Characterization and Identification of Na-Cl Sources in Ground Water: Ground Water, v. 44, no. 2, p. 176-187, doi 10.1111/j.1745-6584.2005.00127.x.

Panno, S., Hackley, K., Hwang, H., Greenberg, S., Krapac, I., Landsberger, S., and O'Kelly, D., 2005, Database for the Characterization and Identification of Sources of Sodium and Chloride in Natural Waters of Illinois: Illinois Department of Natural Resources and Illinois State Geological Survey Open File Series 2005-1, 21 p. 
Panno, S., Kelly W.R., and Baranski, E.L., 2019, Hydrogeochemical controls on aquifer of northwestern Illinois’ Driftless Area, USA: Environmental Earth Sciences, v. 78, no. 9, p. 1-15, doi 10.1007/s12665-019-8271-7.

Panno, S., Kelly, W.R., Martinsek, A.T., and Hackley, K.C., 2006b, Estimating Background and Threshold Nitrate Concentrations Using Probability Graphs: Ground Water, v. 44, no. 5, p. 697-709, doi 10.1111/j.1745-6584.2006.00240.x.

Peterson, E.W. and Benning, C., 2013, Factors influencing nitrate within a low-gradient agricultural stream: Environmental Earth Sciences, v. 68, no. 5, p. 1233-1245, doi 10.1007/s12665-012-1821-X.

Prosser, R.S., McInnis Q.R.R., Exall, K., and Gillis, P.L., 2017, Assessing the toxicity and risk of salt-impacted winter road runoff to early life stages of freshwater mussels in the Canadian province of Ontario: Environmental Pollution, v. 230, p. 589-597, doi 10.1016/j.e nvpol.2017.07.001.

Redemann, C.T., Meikle R.W., and Widofsky J.G., 1964, The Loss of 2-Chloro6 (trichloromethyl)- pyridine from Soil: Agricultural and Food Chemistry, v. 12, no. 3, p. 207-209, doi 10.1021/jf60133a004.

Rivett, M.O., Cuthbert, M.O., Gamble, R., Connon, L.E., Pearson, A., Sheply, M.G., and Davis, J., 2016, Highway deicing salt dynamic runoff to surface water and subsequent infiltration to groundwater during severe UK winters: Science of the Total Environment, v. 565, p. 324-338, doi https://doi.org/10.1016/j.scitotenv.2016.04.095.

Rufatti, M., Supporting Scientist, Illinois State University, Personal Communication and Unpublished Survey, 2019. 
Schulz, C.J. and Cañedo-Argüelles, M., 2018, Lost in translation: the German literature on freshwater salinization: Philosophical Transactions of the Royal Society B, v. 374 , no. 1764, p. 1-11, 10.1098/rstb.2018.0007.

Stets, E.G., Lee, C.J., Lytle, D.A., and Schock M.R., 2017, Increasing Chloride in rivers of the conterminous U.S. and linkages to potential corrosivity and lead action level exceedances in drinking water: Science of the Total Environment, v. 616-614, no. 1, p. 1498-1509, doi 10.1016/j.scitotenv.2017.07.119.

Stokes, J., Mclean County Engineer, Personal Communication, 2018.

Stripe, C.R., Cunningham, M.A., Menking, K.M., 2017, How will Climate Change Affect Road Salt Export from Watersheds?: Water, Air, \& Soil Pollution, v. 228, no. 362, p. 115, doi 10.1007/s11270-017-3455-9.

Tyree, M., Clay, N., Polaskey, S., and Entrekin, S., 2016, Salt in in our streams: even small sodium addition can have negative effects on detritivores; Hydrobiologia, v. 775, no. 1, p. 109-122, doi 10.1007/s10750-016-2718-6.

United States Department of Agriculture, 2018, USDA's National Agricultural Statistics Service Illinois Field Office: https://www.nass.usda.gov/Statistics_by_State/Illinois/Publication s/County_Estimates/ (accessed April 2019).

United States Environmental Protection Agency, 2011, 2011 Edition of the Drinking Water Standards and Health Advisories, U.S. Environmental Protection Agency, Washington, DC, EPA 820-R-11-002, 18 p. 


\title{
APPENDIX A: WEEKLY FIELD AND MAJOR ION DATA
}

\author{
1. Dashes mean values are missing or were not measured \\ 2. All ion concentrations are in $\mathrm{mg} / \mathrm{l}$ \\ 3. SpC - Specific Conductance ( $\mu \mathrm{S} / \mathrm{Cm})$ \\ 4. $Q$ - Measured Stream or Tile Discharge $\left(\mathrm{m}^{3} / \mathrm{s}\right)$
}

Table 1. Data from WS1.

\begin{tabular}{|c|c|c|c|c|c|c|c|c|c|c|c|c|c|}
\hline Date & Q & $\mathrm{SpC}$ & $\mathrm{pH}$ & $\mathrm{F}^{-}$ & $\mathrm{Cl}^{-}$ & $\mathrm{Br}^{-}$ & $\mathrm{NO}_{3}-\mathrm{N}$ & $\mathrm{PO}_{4}-\mathrm{P}$ & $\mathrm{SO}_{4}{ }^{2-}$ & $\mathrm{Ca}^{2+}$ & $\mathrm{Mg}^{2+}$ & $\mathrm{Na}^{+}$ & $\mathrm{K}^{+}$ \\
\hline $2 / 17 / 189: 30$ & - & 1439 & 7.63 & 0.1 & 335 & $<0.05$ & 1.0 & 0.0 & 12.0 & 81.2 & 26.6 & 193 & 4.5 \\
\hline 2/23/18 9:30 & - & 720.0 & 7.82 & 0.2 & 92.9 & $<0.05$ & 5.4 & 0.0 & 11.1 & 77.2 & 22.0 & 42.9 & 2.5 \\
\hline $3 / 2 / 20189: 30$ & - & 719.6 & 7.74 & 0.2 & 76.2 & $<0.05$ & 6.6 & 0.0 & 10.3 & 72.4 & 18.2 & 25.2 & 1.2 \\
\hline $3 / 9 / 20189: 30$ & - & 798.9 & 8.31 & 0.2 & 75.2 & $<0.05$ & 6.8 & 0.0 & 12.7 & 68.7 & 12.7 & 12.2 & 0.5 \\
\hline $3 / 16 / 20189: 30$ & 0.192 & 782.5 & 8.45 & 0.2 & 71.7 & $<0.05$ & 6.5 & 2.0 & 13.4 & 58.4 & 10.1 & 8.3 & 0.7 \\
\hline $3 / 23 / 20189: 30$ & 0.210 & 792.0 & 8.33 & 0.1 & 73.3 & 0.28 & 6.2 & 0.0 & 12.9 & 96.9 & 32.9 & 32.6 & 1.2 \\
\hline $3 / 30 / 20189: 30$ & 1.189 & 700.1 & 7.91 & 0.1 & 62.2 & 0.27 & 9.4 & 0.0 & 9.4 & 87.7 & 27.9 & 28.7 & 2.9 \\
\hline 4/6/2018 9:30 & 0.620 & 766.1 & 8.15 & 0.2 & 68.9 & $<0.05$ & 9.4 & 0.0 & 10.9 & 97.4 & 30.2 & 29.0 & 1.1 \\
\hline 4/13/2018 9:30 & 0.349 & 752.0 & 8.21 & 0.1 & 61.6 & $<0.05$ & 9.0 & 0.0 & 11.2 & 97.7 & 33.8 & 26.6 & 1.1 \\
\hline $4 / 20 / 20189: 30$ & - & 746.2 & 8.15 & 0.2 & 60.0 & $<0.05$ & 9.4 & 0.0 & 11.0 & 94.3 & 18.8 & 14.7 & 0.6 \\
\hline $4 / 27 / 20189: 30$ & 0.343 & 739.0 & 8.18 & 0.1 & 56.7 & $<0.05$ & 9.2 & 0.0 & 11.3 & 96.3 & 34.0 & 23.9 & 1.0 \\
\hline $5 / 4 / 20189: 30$ & 0.282 & 763.0 & 8.24 & 0.1 & 64.1 & $<0.05$ & 7.9 & 0.0 & 11.2 & 97.5 & 33.6 & 29.5 & 1.3 \\
\hline $5 / 11 / 20189: 30$ & 0.204 & 731.0 & 8.02 & 0.2 & 51.1 & $<0.05$ & 7.7 & 0.0 & 11.3 & 95.8 & 35.3 & 21.1 & 1.0 \\
\hline $5 / 18 / 20189: 30$ & 0.151 & 733.0 & 8.19 & 0.1 & 51.2 & $<0.05$ & 7.4 & 0.0 & 11.6 & 97.3 & 36.6 & 21.7 & 0.9 \\
\hline $5 / 25 / 20189: 30$ & 0.138 & 721.0 & 7.95 & 0.2 & 46.8 & $<0.05$ & 6.7 & 0.0 & 11.9 & 93.6 & 36.1 & 18.9 & 0.9 \\
\hline $6 / 1 / 20189: 30$ & - & 686.0 & 7.52 & 0.2 & 57.8 & $<0.05$ & 7.0 & 0.1 & 9.9 & 79.0 & 30.3 & 27.6 & 3.1 \\
\hline 6/8/2018 9:30 & 0.182 & 723.0 & 7.75 & 0.2 & 46.5 & $<0.05$ & 7.5 & 0.0 & 10.9 & 98.5 & 34.7 & 19.6 & 1.0 \\
\hline $6 / 15 / 20189: 30$ & 0.669 & 679.0 & 7.70 & 0.2 & 38.1 & $<0.05$ & 9.9 & 0.0 & 8.3 & 94.6 & 32.0 & 16.1 & 1.5 \\
\hline $6 / 22 / 20189: 30$ & - & 449.0 & 7.40 & 0.2 & 33.2 & $<0.05$ & 5.4 & 0.4 & 5.5 & 49.3 & 17.6 & 17.6 & 3.2 \\
\hline $6 / 29 / 20189: 30$ & 0.381 & 706.0 & 7.83 & 0.2 & 39.4 & $<0.05$ & 8.9 & 0.0 & 9.7 & 94.2 & 30.2 & 15.1 & 1.1 \\
\hline 7/6/2018 9:30 & 0.182 & 721.0 & 8.02 & 0.2 & 40.9 & $<0.05$ & 7.4 & 0.0 & 10.7 & 94.0 & 33.2 & 17.1 & 1.1 \\
\hline $7 / 13 / 20189: 30$ & 0.076 & 724.0 & 8.02 & 0.2 & 40.8 & $<0.05$ & 5.0 & 0.0 & 13.0 & 98.2 & 22.5 & 9.9 & 0.6 \\
\hline $7 / 20 / 20189: 30$ & 0.045 & 737.0 & 8.05 & 0.2 & 44.3 & $<0.05$ & 2.9 & 0.0 & 14.3 & 94.9 & 31.0 & 19.4 & 1.1 \\
\hline $7 / 27 / 20189: 30$ & 0.018 & 690.0 & 8.07 & 0.2 & 46.4 & $<0.05$ & 1.3 & 0.0 & 15.0 & 61.2 & 30.8 & 18.2 & 0.5 \\
\hline $8 / 3 / 20189: 30$ & 0.006 & 666.0 & 7.90 & 0.2 & 37.7 & $<0.05$ & 0.9 & 0.0 & 15.9 & 82.3 & 33.8 & 14.6 & 0.8 \\
\hline $8 / 10 / 20189: 30$ & 0.001 & 624.0 & 7.88 & 0.2 & 38.8 & $<0.05$ & 0.9 & 0.0 & 14.4 & 67.3 & 13.5 & 5.4 & 0.3 \\
\hline $8 / 17 / 20189: 30$ & 0.089 & 586.0 & 7.76 & 0.2 & 36.1 & $<0.05$ & 0.7 & 0.0 & 13.3 & 61.6 & 18.9 & 8.7 & 1.0 \\
\hline $8 / 24 / 20189: 30$ & & 507.4 & 8.01 & 0.2 & 39.4 & $<0.05$ & 0.6 & 0.0 & 12.7 & 55.4 & 30.3 & 16.6 & 1.6 \\
\hline $8 / 31 / 20189: 30$ & 0.023 & 439.4 & 7.94 & 0.2 & 45.8 & $<0.05$ & 0.8 & 0.0 & 7.3 & 47.5 & 15.4 & 25.8 & 2.9 \\
\hline 9/7/2018 9:30 & - & 489.2 & 7.79 & 0.2 & 43.4 & $<0.05$ & 0.5 & 0.0 & 9.2 & 52.7 & 21.1 & 22.3 & 3.2 \\
\hline 9/14/2018 9:30 & - & 610.0 & 8.08 & 0.2 & 69.1 & 0.05 & 0.7 & 0.0 & 10.4 & 59.1 & 23.0 & 38.0 & 2.8 \\
\hline $9 / 21 / 20189: 30$ & - & 597.0 & 7.81 & 0.2 & 56.2 & $<0.05$ & 0.5 & 0.1 & 13.4 & 52.7 & 25.9 & 30.3 & 4.3 \\
\hline $9 / 28 / 20189: 30$ & - & 603.9 & 8.03 & 0.1 & 60.9 & 0.05 & 0.4 & 0.0 & 10.4 & 53.4 & 26.6 & 29.5 & 4.2 \\
\hline 10/5/2018 9:30 & - & 421.2 & 7.89 & 0.1 & 42.8 & $<0.05$ & 0.4 & 0.1 & 11.6 & 45.7 & 27.0 & 21.7 & 3.8 \\
\hline $10 / 12 / 20189: 30$ & 0.140 & 647.2 & 7.94 & 0.2 & 59.2 & 0.05 & 1.7 & 0.1 & 10.6 & 63.1 & 26.7 & 32.3 & 2.6 \\
\hline 10/19/2018 9:30 & 0.052 & 657.8 & 7.89 & 0.2 & 62.6 & 0.06 & 1.3 & 0.0 & 10.9 & 71.3 & 24.2 & 30.6 & 1.9 \\
\hline $10 / 26 / 20189: 30$ & 0.033 & 740.0 & 7.58 & 0.2 & 64.7 & 0.07 & 0.8 & 0.0 & 14.7 & 78.8 & 25.7 & 24.4 & 2.0 \\
\hline 11/2/2018 9:30 & 0.236 & 706.9 & 7.60 & 0.2 & 64.4 & 0.05 & 2.6 & 0.0 & 11.0 & 80.6 & 25.0 & 29.3 & 1.8 \\
\hline 11/9/2018 9:30 & 0.106 & 799.9 & 7.46 & 0.1 & 69.3 & 0.07 & 2.4 & 0.0 & 13.2 & 83.8 & 29.6 & 33.9 & 1.5 \\
\hline 11/16/2018 9:30 & 0.072 & 779.1 & 7.86 & 0.1 & 66.8 & 0.05 & 2.6 & 0.0 & 14.0 & 108 & 38.5 & 37.7 & 1.6 \\
\hline 11/23/2018 9:30 & 0.084 & 851.0 & 7.88 & 0.2 & 88.3 & 0.07 & 2.8 & 0.0 & 14.2 & 106 & 31.9 & 39.6 & 1.2 \\
\hline $11 / 30 / 20189: 30$ & 0.290 & 827.0 & 7.84 & 0.1 & 79.6 & $<0.05$ & 4.7 & 0.1 & 12.3 & 113 & 39.5 & 49.9 & 1.8 \\
\hline $12 / 7 / 20189: 30$ & 0.423 & 794.8 & 7.81 & 0.2 & 65.2 & $<0.05$ & 6.3 & 0.0 & 11.8 & 120 & 41.6 & 37.9 & 1.5 \\
\hline 12/14/2018 9:30 & 0.481 & 1042 & 7.50 & 0.1 & 174 & 0.06 & 4.5 & 0.1 & 10.8 & 113 & 34.6 & 120 & 3.2 \\
\hline 1/4/2019 9:30 & 0.873 & 714.7 & 7.56 & 0.1 & 50.8 & $<0.05$ & 8.7 & 0.1 & 10.9 & 111 & 41.5 & 26.1 & 1.5 \\
\hline $1 / 11 / 20199: 30$ & 0.424 & 758.9 & 7.67 & 0.1 & 50.2 & $<0.05$ & 8.6 & 0.1 & 12.0 & 90.7 & 29.8 & 14.6 & 0.6 \\
\hline 1/18/2019 9:30 & 0.320 & 887.0 & 7.69 & 0.2 & 93.9 & 0.07 & 7.9 & 0.0 & 12.2 & 109 & 45.5 & 62.6 & 1.4 \\
\hline $1 / 25 / 20199: 30$ & - & 814.0 & 7.59 & 0.2 & 89.8 & $<0.05$ & 8.3 & 0.0 & 10.6 & 83.6 & 32.5 & 42.3 & 1.8 \\
\hline 2/1/2019 9:30 & - & 842.0 & 8.30 & 0.2 & 72.0 & $<0.05$ & 8.5 & 0.0 & 11.7 & 81.1 & 28.7 & 23.6 & 0.9 \\
\hline $2 / 17 / 20199: 30$ & - & 732.0 & 7.56 & 0.2 & 61.2 & 0.11 & 8.4 & 0.0 & 10.0 & 84.3 & 31.7 & 25.3 & 1.4 \\
\hline
\end{tabular}


Table 2. Data from WS1.25.

\begin{tabular}{|c|c|c|c|c|c|c|c|c|c|c|c|c|c|}
\hline Date & Q & $\mathrm{SpC}$ & $\mathrm{pH}$ & $\mathrm{F}^{-}$ & $\mathrm{Cl}^{-}$ & $\mathrm{Br}^{-}$ & $\mathrm{NO}_{3}-\mathrm{N}$ & $\mathrm{PO}_{4}-\mathrm{P}$ & $\mathrm{SO}_{4}{ }^{2-}$ & $\mathrm{Ca}^{2+}$ & $\mathrm{Mg}^{2+}$ & $\mathrm{Na}^{+}$ & $\mathrm{K}^{+}$ \\
\hline $7 / 27 / 20188: 30$ & 0.012 & 713.0 & 7.81 & 0.2 & 38.3 & $<0.05$ & 1.2 & 0.0 & 15.5 & 97.5 & 39.4 & 17.8 & 1.1 \\
\hline 8/3/2018 8:30 & 0.005 & 732.0 & 7.64 & 0.2 & 41.3 & $<0.05$ & 0.4 & 0.0 & 14.8 & 96.7 & 31.3 & 13.5 & 1.1 \\
\hline $8 / 10 / 20188: 30$ & 0.001 & 711.0 & 7.65 & 0.2 & 36.2 & $<0.05$ & 0.4 & 0.4 & 9.7 & 82.4 & 35.7 & 12.8 & 2.2 \\
\hline $8 / 17 / 20188: 30$ & 0.048 & 530.0 & 7.62 & 0.3 & 48.4 & $<0.05$ & 0.6 & 0.1 & 10.8 & 54.9 & 25.1 & 23.7 & 4.0 \\
\hline $8 / 24 / 20188: 30$ & - & 414.2 & 7.84 & 0.1 & 36.0 & $<0.05$ & 0.5 & 0.2 & 3.0 & 24.7 & 7.7 & 28.3 & 2.0 \\
\hline $8 / 31 / 20188: 30$ & 0.009 & 570.0 & 7.83 & 0.2 & 65.4 & $<0.05$ & 0.4 & 0.0 & 12.4 & 61.3 & 21.4 & 34.3 & 3.4 \\
\hline 9/7/2018 8:30 & 0.006 & 661.0 & 7.82 & 0.2 & 67.0 & $<0.05$ & 0.4 & 0.0 & 14.0 & 72.3 & 29.7 & 35.9 & 3.3 \\
\hline $9 / 14 / 188: 30$ & - & 655.0 & 8.26 & 0.2 & 84.3 & $<0.05$ & 0.4 & 0.3 & 11.3 & 58.7 & 24.6 & 48.5 & 4.2 \\
\hline $9 / 21 / 188: 30$ & - & 590.0 & 7.74 & 0.3 & 161 & 0.09 & 0.4 & 0.5 & 7.1 & 74.1 & 22.6 & 100.3 & 9.0 \\
\hline $9 / 28 / 188: 30$ & - & 489.1 & 8.09 & 0.1 & 53.0 & $<0.05$ & 0.4 & 0.0 & 17.8 & 44.4 & 15.8 & 29.2 & 5.0 \\
\hline 10/5/18 8:30 & - & 62.3 & 7.73 & 0.2 & 93.7 & $<0.05$ & 0.5 & 0.2 & 11.2 & 53.0 & 15 & 92.2 & 6.3 \\
\hline $10 / 12 / 188: 30$ & 0.124 & 641.1 & 7.71 & 0.2 & 59.0 & $<0.05$ & 1.6 & 0.1 & 11.0 & 86.9 & 29.1 & 34.3 & 2.4 \\
\hline $10 / 19 / 188: 30$ & 0.051 & 660.2 & 7.71 & 0.2 & 62.5 & 0.08 & 1.1 & 0.0 & 11.2 & 86.3 & 31.8 & 41.6 & 2.4 \\
\hline 10/26/18 8:30 & 0.024 & 751.0 & 7.49 & 0.2 & 65.5 & 0.06 & 0.8 & 0.0 & 15.4 & 107 & 39.9 & 42.3 & 2.8 \\
\hline 11/2/18 8:30 & 0.194 & 686.7 & 7.35 & 0.2 & 61.9 & 0.07 & 2.4 & 0.0 & 10.9 & 92.7 & 31.6 & 37.4 & 2.3 \\
\hline 11/9/18 8:30 & 0.092 & 787.0 & 10.15 & 0.1 & 64.9 & 0.10 & 2.3 & 0.0 & 14.1 & 109 & 38.9 & 43.5 & 3.3 \\
\hline $11 / 16 / 188: 30$ & 0.056 & 765.3 & 7.68 & 0.2 & 68.0 & 0.07 & 2.4 & 0.0 & 13.2 & 115 & 41.7 & 41.8 & 1.8 \\
\hline 11/23/2018 9:00 & 0.065 & 827.0 & 7.65 & 0.2 & 81.0 & $<0.05$ & 2.7 & 0.0 & 14.3 & 113 & 40.9 & 51.5 & 1.8 \\
\hline $11 / 30 / 20188: 30$ & 0.231 & 823.0 & 7.61 & 0.2 & 81.3 & $<0.05$ & 4.5 & 0.0 & 12.2 & 120 & 42.3 & 53.9 & 1.8 \\
\hline 12/7/2018 8:30 & 0.318 & 802.8 & 7.47 & 0.2 & 68.9 & 0.05 & 6.1 & 0.1 & 12.1 & 106 & 38.0 & 38.3 & 1.5 \\
\hline $12 / 14 / 20188: 30$ & 0.309 & 780.6 & 7.31 & 0.1 & 83.0 & $<0.05$ & 5.2 & 0.0 & 9.9 & 114 & 33.8 & 50.8 & 1.9 \\
\hline 1/4/2019 8:30 & 0.606 & 716.2 & 7.16 & 0.2 & 50.5 & $<0.05$ & 8.4 & 0.1 & 10.5 & 103 & 37.4 & 24.8 & 1.5 \\
\hline $1 / 11 / 20198: 30$ & 0.288 & 760.3 & 7.31 & 0.2 & 50.6 & $<0.05$ & 8.2 & 0.0 & 12.1 & 117 & 42.7 & 24.3 & 1.1 \\
\hline $1 / 18 / 20198: 30$ & 0.213 & 993.0 & 7.34 & 0.2 & 126 & 0.09 & 7.5 & 0.0 & 12.2 & 123 & 43.3 & 82.0 & 1.5 \\
\hline $1 / 25 / 20198: 30$ & - & 877.2 & 7.03 & 0.2 & 97.4 & 0.09 & 7.7 & 0.0 & 10.7 & 86.7 & 33.4 & 47.6 & 2.0 \\
\hline 2/17/2019 8:30 & - & 740.0 & 7.60 & 0.2 & 62.6 & $<0.05$ & 8.3 & 0.1 & 10.0 & 81.0 & 32.1 & 26.2 & 1.4 \\
\hline
\end{tabular}


Table 3. Data from WS1.5.

\begin{tabular}{|c|c|c|c|c|c|c|c|c|c|c|c|c|c|}
\hline Date & Q & $\mathrm{SpC}$ & $\mathrm{pH}$ & $\mathrm{F}^{-}$ & $\mathrm{Cl}^{-}$ & $\mathrm{Br}^{-}$ & $\mathrm{NO}_{3}-\mathrm{N}$ & $\mathrm{PO}_{4}-\mathrm{P}$ & $\mathrm{SO}_{4}{ }^{2-}$ & $\mathrm{Ca}^{2+}$ & $\mathrm{Mg}^{2+}$ & $\mathrm{Na}^{+}$ & $\mathrm{K}^{+}$ \\
\hline 2/16/2018 8:30 & - & 1558 & 7.64 & 0.1 & 347 & 0.17 & 0.4 & 0.0 & 12.1 & 80.9 & 27.7 & 220 & 4.1 \\
\hline 2/23/2018 8:30 & - & 716.6 & 7.59 & 0.2 & 96.8 & $<0.05$ & 4.5 & 0.2 & 10.2 & 72.8 & 23.8 & 56.0 & 4.4 \\
\hline 3/2/2018 8:30 & - & 712.2 & 7.69 & 0.2 & 70.4 & $<0.05$ & 5.0 & 0.1 & 9.6 & 84.6 & 25.0 & 38.1 & 2.7 \\
\hline $3 / 9 / 20188: 30$ & 0.217 & 803.2 & 7.86 & 0.1 & 77.6 & $<0.05$ & 5.7 & 0.0 & 12.5 & 90.7 & 31.9 & 38.4 & 1.5 \\
\hline 3/16/2018 8:30 & 0.106 & 818.0 & 8.16 & 0.1 & 78.0 & $<0.05$ & 5.3 & 0.0 & 13.3 & 92.5 & 18.3 & 19.6 & 0.3 \\
\hline 3/23/2018 8:30 & 0.104 & 810.8 & 8.03 & 0.1 & 75.8 & $<0.05$ & 5.4 & 0.0 & 12.8 & 102 & 35.6 & 37.5 & 1.4 \\
\hline 3/30/2018 8:30 & 0.730 & 709.8 & 7.68 & 0.2 & 67.8 & $<0.05$ & 7.9 & 0.0 & 9.4 & 85.5 & 28.8 & 35.5 & 2.1 \\
\hline 4/6/2018 8:30 & 0.346 & 796.0 & 7.80 & 0.2 & 78.5 & $<0.05$ & 7.8 & 0.0 & 11.0 & 97.0 & 33.6 & 40.7 & 1.4 \\
\hline 4/13/2018 8:30 & 0.162 & 788.0 & 7.81 & 0.1 & 71.7 & $<0.05$ & 7.3 & 0.0 & 11.5 & 103 & 36.0 & 36.2 & 1.2 \\
\hline 4/20/2018 8:30 & - & 778.0 & 7.86 & 0.1 & 70.3 & $<0.05$ & 7.2 & 0.0 & 11.5 & 104 & 35.0 & 34.9 & 1.2 \\
\hline 4/27/2018 8:30 & 0.168 & 772.0 & 7.74 & 0.1 & 65.7 & $<0.05$ & 7.3 & 0.0 & 11.4 & 105 & 37.4 & 32.7 & 1.2 \\
\hline 5/4/2018 8:30 & 0.156 & 789.0 & 7.80 & 0.1 & 68.7 & $<0.05$ & 6.3 & 0.0 & 11.2 & 100 & 35.4 & 34.6 & 1.2 \\
\hline 5/11/2018 8:30 & 0.090 & 766.0 & 7.70 & 0.1 & 59.7 & $<0.05$ & 6.5 & 0.0 & 11.5 & 101 & 37.8 & 28.1 & 1.1 \\
\hline $5 / 18 / 2018$ 8:30 & 0.081 & 758.0 & 7.75 & 0.1 & 52.5 & $<0.05$ & 6.6 & 0.0 & 11.7 & 109 & 39.7 & 23.7 & 0.8 \\
\hline 5/25/2018 8:30 & 0.058 & 756.0 & 7.59 & 0.1 & 49.2 & $<0.05$ & 0.4 & 0.0 & 11.8 & 107 & 38.5 & 21.6 & 0.9 \\
\hline $6 / 1 / 20188: 30$ & & 693.0 & 7.20 & 0.2 & 58.6 & $<0.05$ & 5.9 & 0.0 & 9.1 & 80.6 & 31.7 & 28.1 & 1.7 \\
\hline
\end{tabular}

Table 4. Data from shallow T3 Well.

\begin{tabular}{rrrrrrrrrrr}
\hline Date & $\mathrm{F}^{-}$ & $\mathrm{Cl}^{-}$ & $\mathrm{Br}^{-}$ & $\mathrm{NO}_{3}-\mathrm{N}$ & $\mathrm{PO}_{4}-\mathrm{P}$ & $\mathrm{SO}_{4}^{2-}$ & $\mathrm{Ca}^{2+}$ & $\mathrm{Mg}^{2+}$ & $\mathrm{Na}^{+}$ & $\mathrm{K}^{+}$ \\
\hline $5 / 16 / 2018$ & 0.1 & 1.3 & 0.13 & 0.7 & 0.0 & 24.5 & 96.6 & 33.7 & 3.7 & 0.4 \\
$6 / 28 / 2018$ & 0.2 & 3.0 & 0.30 & 0.7 & 0.0 & 27.3 & 118 & 36.7 & 4.8 & 0.4 \\
$7 / 25 / 2018$ & 0.2 & 2.3 & 0.12 & 0.5 & 0.0 & 57.6 & 96.0 & 41.3 & 2.8 & 0.2 \\
$8 / 24 / 2018$ & 0.2 & 2.3 & 0.10 & 0.4 & 0.1 & 35.9 & 105 & 44.8 & 6.0 & 1.8 \\
$9 / 27 / 2018$ & 0.1 & 2.6 & 0.11 & 0.4 & 0.0 & 36.4 & 127 & 45.6 & 3.3 & 1.5 \\
\hline
\end{tabular}


Table 5. Data from WS2. Includes road salt runoff sample.

\begin{tabular}{|c|c|c|c|c|c|c|c|c|c|c|c|c|c|}
\hline Date & Q & $\mathrm{SpC}$ & $\mathrm{pH}$ & $\mathrm{F}^{-}$ & $\mathrm{Cl}^{-}$ & $\mathrm{Br}^{-}$ & $\mathrm{NO}_{3}-\mathrm{N}$ & $\mathrm{PO}_{4}-\mathrm{P}$ & $\mathrm{SO}_{4}^{2-}$ & $\mathrm{Ca}^{2+}$ & $\mathrm{Mg}^{2+}$ & $\mathrm{Na}^{+}$ & $\mathrm{K}^{+}$ \\
\hline $2 / 16 / 187: 30$ & - & 679 & 7.57 & 0.1 & 108 & $<0.05$ & 0.6 & 0.0 & 8.2 & 35.7 & 12.5 & 31.8 & 1.2 \\
\hline $2 / 23 / 187: 30$ & - & 651 & 7.72 & 0.2 & 89.9 & $<0.05$ & 3.1 & 0.0 & 10.0 & 59.8 & 20.0 & 54.8 & 3.6 \\
\hline $3 / 2 / 18$ 7:30 & - & 721 & 7.93 & 0.2 & 100 & $<0.05$ & 4.5 & 0.0 & 10.8 & 40.5 & 9.8 & 20.0 & 0.8 \\
\hline 3/9/18 7:30 & 0.073 & 779 & 8.13 & 0.1 & 95.9 & $<0.05$ & 4.2 & 0.0 & 10.8 & 52.1 & 22.3 & 45.0 & 2.1 \\
\hline $3 / 16 / 187: 30$ & 0.026 & 798 & 8.24 & 0.2 & 97.9 & $<0.05$ & 4.1 & 0.0 & 11.0 & 64.7 & 13.0 & 23.5 & 0.9 \\
\hline $3 / 23 / 187: 30$ & 0.036 & 790 & 8.21 & 0.1 & 98.9 & $<0.05$ & 3.9 & 1.4 & 11.2 & 73.7 & 24.9 & 46.6 & 1.7 \\
\hline $3 / 30 / 187: 30$ & 0.248 & 704 & 7.63 & 0.2 & 89.2 & $<0.05$ & 4.4 & 0.2 & 9.3 & 68.1 & 23.8 & 54.8 & 1.7 \\
\hline 4/6/18 7:30 & 0.097 & 865 & 8.37 & 0.2 & 124 & $<0.05$ & 5.1 & 0.0 & 10.2 & 78.7 & 23.4 & 60.9 & 1.9 \\
\hline $4 / 13 / 187: 30$ & 0.053 & 834 & 8.48 & 0.1 & 116 & $<0.05$ & 4.9 & 0.0 & 10.5 & 80.0 & 25.8 & 57.8 & 1.8 \\
\hline $4 / 20 / 187: 30$ & - & 798 & 8.43 & 0.2 & 107 & $<0.05$ & 4.3 & 0.0 & 10.6 & 78.1 & 18.7 & 37.2 & 0.6 \\
\hline $4 / 27 / 187: 30$ & 0.043 & 780 & 8.35 & 0.1 & 105 & $<0.05$ & 4.2 & 0.0 & 10.9 & 71.2 & 30.8 & 60.4 & 1.7 \\
\hline 5/4/18 7:30 & 0.036 & 809 & 8.17 & 0.2 & 103 & $<0.05$ & 4.1 & 0.0 & 10.9 & 76.6 & 31.7 & 57.0 & 2.0 \\
\hline $5 / 11 / 187: 30$ & 0.017 & 734 & 8.25 & 0.2 & 104 & $<0.05$ & 2.8 & 0.0 & 11.3 & 52.9 & 30.4 & 56.7 & 2.0 \\
\hline $5 / 18 / 187: 30$ & 0.017 & 676 & 8.54 & 0.2 & 102 & $<0.05$ & 1.7 & 0.0 & 11.1 & 39.6 & 31.8 & 58.4 & 1.9 \\
\hline $5 / 25 / 187: 30$ & 0.016 & 662 & 8.42 & 0.2 & 101 & $<0.05$ & 1.2 & 0.0 & 10.3 & 36.6 & 31.4 & 54.9 & 2.0 \\
\hline $6 / 1 / 187: 30$ & - & 612 & 8.10 & 0.2 & 82.6 & $<0.05$ & 1.9 & 0.0 & 8.4 & 42.2 & 24.9 & 41.0 & 2.3 \\
\hline 6/8/18 7:30 & 0.026 & 659 & 7.65 & 0.2 & 78.5 & $<0.05$ & 1.9 & 0.0 & 8.5 & 55.2 & 28.8 & 40.7 & 2.0 \\
\hline $6 / 15 / 187: 30$ & 0.095 & 618 & 7.62 & 0.2 & 59.7 & $<0.05$ & 4.6 & 0.0 & 6.9 & 61.5 & 25.1 & 33.7 & 2.2 \\
\hline $6 / 22 / 187: 30$ & - & 413 & 7.36 & 0.2 & 43.1 & $<0.05$ & 2.4 & 0.2 & 4.6 & 35.7 & 16.9 & 28.1 & 3.1 \\
\hline $6 / 29 / 187: 30$ & 0.054 & 561 & 7.95 & 0.2 & 60.0 & $<0.05$ & 2.7 & 0.0 & 6.2 & 45.8 & 22.8 & 33.3 & 2.1 \\
\hline 7/6/18 7:30 & 0.022 & 573 & 7.84 & 0.2 & 63.0 & $<0.05$ & 0.0 & 1.1 & 6.6 & 44.1 & 26.1 & 38.1 & 2.2 \\
\hline $7 / 13 / 187: 30$ & 0.004 & 552 & 7.66 & 0.2 & 67.2 & $<0.05$ & 0.9 & 0.0 & 6.7 & 30.4 & 15.5 & 22.1 & 0.6 \\
\hline $7 / 20 / 187: 30$ & 0.002 & 512 & 7.93 & 0.2 & 65.4 & $<0.05$ & 0.5 & 0.0 & 6.1 & 31.4 & 19.7 & 31.8 & 1.4 \\
\hline $7 / 27 / 187: 30$ & - & 1190 & 6.74 & 0.2 & 130 & 0.26 & 0.4 & 0.0 & 11.4 & 143 & 49.4 & 56.8 & 1.9 \\
\hline 8/3/18 7:30 & - & 1210 & 6.68 & 0.1 & 126 & 0.25 & 0.4 & 0.0 & 12.2 & 151 & 50.0 & 53.7 & 1.6 \\
\hline $8 / 10 / 187: 30$ & - & 1220 & 6.72 & 0.2 & 130 & 0.24 & 0.4 & 0.0 & 12.3 & 148 & 35.5 & 39.4 & 1.0 \\
\hline $8 / 17 / 187: 30$ & - & 1130 & 6.69 & 0.2 & 93.8 & 0.08 & 0.6 & 0.1 & 8.2 & 57.3 & 19.1 & 50.6 & 1.2 \\
\hline $8 / 24 / 187: 30$ & 0.007 & 273.9 & 7.74 & 0.1 & 27.8 & $<0.05$ & 0.6 & 0.3 & 2.3 & 6.9 & 0.0 & 29.5 & 1.1 \\
\hline $8 / 31 / 187: 30$ & - & 1180 & 6.82 & 0.2 & 74.3 & 0.09 & 0.5 & 0.0 & 5.3 & 58.1 & 23.2 & 37.4 & 0.7 \\
\hline 9/7/18 7:30 & 0.001 & 291 & 8.03 & 0.1 & 44.6 & $<0.05$ & 0.7 & 0.6 & 2.6 & 10.3 & 1.5 & 48.6 & 1.6 \\
\hline $9 / 14 / 187: 30$ & - & 1320 & 6.84 & 0.2 & 155 & 0.31 & 0.4 & 0.0 & 13.3 & 157 & 54.7 & 56.5 & 1.1 \\
\hline $9 / 21 / 187: 30$ & - & 1140 & 6.83 & 0.2 & 106 & 0.17 & 0.5 & 0.0 & 8.8 & 92.1 & 32.9 & 49.0 & 2.8 \\
\hline $9 / 28 / 187: 30$ & - & 1200 & 6.95 & 0.1 & 150 & 0.27 & 0.4 & 0.0 & 12.0 & 128 & 41.4 & 51.5 & 1.9 \\
\hline $10 / 5 / 187: 30$ & - & 215 & 8.04 & 0.1 & 32.2 & $<0.05$ & 0.7 & 1.2 & 2.5 & 10.9 & 2.2 & 26.8 & 2.6 \\
\hline $10 / 12 / 187: 30$ & 0.039 & 438 & 7.86 & 0.2 & 49.3 & $<0.05$ & 1.1 & 0.1 & 5.4 & 35.7 & 18.1 & 32.8 & 3.0 \\
\hline $10 / 19 / 187: 30$ & 0.023 & 488 & 8.05 & 0.2 & 54.1 & 0.06 & 1.0 & 0.0 & 5.5 & 40.3 & 20.1 & 35.9 & 2.8 \\
\hline $10 / 26 / 187: 30$ & 0.012 & 487 & 8.20 & 0.2 & 56.8 & 0.06 & 0.8 & 0.1 & 5.6 & 40.5 & 19.3 & 42.7 & 2.8 \\
\hline $11 / 2 / 187: 30$ & 0.079 & 506 & 7.74 & 0.2 & 54.3 & 0.05 & 1.2 & 0.0 & 5.7 & 43.1 & 20.9 & 39.2 & 3.0 \\
\hline 11/9/18 7:30 & 0.036 & 561 & 6.37 & 0.2 & 58.3 & $<0.05$ & 1.5 & 0.0 & 6.2 & 49.6 & 21.4 & 40.0 & 2.5 \\
\hline $11 / 16 / 187: 30$ & 0.030 & 572 & 8.02 & 0.2 & 60.8 & 0.07 & 1.6 & 0.0 & 6.5 & 54.9 & 23.4 & 43.1 & 2.7 \\
\hline $11 / 23 / 187: 30$ & 0.020 & 669 & 8.10 & 0.2 & 86.2 & $<0.05$ & 1.8 & 0.0 & 6.9 & 55.1 & 24.9 & 61.1 & 2.7 \\
\hline 11/30/18 7:30 & 0.069 & 701 & 7.69 & 0.2 & 88.0 & $<0.05$ & 3.0 & 0.1 & 7.9 & 64.1 & 25.8 & 63.5 & 2.8 \\
\hline 12/7/18 7:30 & 0.073 & 701 & 7.43 & 0.2 & 79.0 & $<0.05$ & 4.3 & 0.1 & 8.6 & 64.5 & 24.2 & 46.2 & 2.4 \\
\hline $12 / 14 / 187: 30$ & 0.095 & 733 & 7.52 & 0.2 & 80.6 & $<0.05$ & 4.6 & 0.0 & 9.1 & 76.6 & 29.4 & 51.3 & 2.4 \\
\hline 1/4/19 7:30 & 0.146 & 643 & 7.04 & 0.2 & 62.7 & $<0.05$ & 5.2 & 0.1 & 8.8 & 70.4 & 26.9 & 37.6 & 2.4 \\
\hline $1 / 11 / 197: 30$ & 0.055 & 709 & 6.06 & 0.2 & 68.2 & $<0.05$ & 5.8 & 0.1 & 9.9 & 72.6 & 29.0 & 40.2 & 2.0 \\
\hline 1/18/19 7:30 & 0.020 & 739 & 7.33 & 0.2 & 80.4 & 0.09 & 5.7 & 0.0 & 9.9 & 81.3 & 32.4 & 45.6 & 1.9 \\
\hline $1 / 25 / 197: 30$ & 0.247 & 851 & 6.75 & 0.2 & 122 & 0.05 & 4.8 & 0.0 & 9.2 & 73.3 & 27.4 & 66.5 & 2.4 \\
\hline 2/17/19 7:30 & 0.094 & 2390 & 8.12 & 0.2 & 637 & 0.11 & 5.1 & 0.1 & 7.9 & 61.4 & 23.0 & 357 & 4.8 \\
\hline Road Salt Runoff & - & 86500 & 7.79 & 0.6 & 31000 & 2.12 & 4.7 & 0.3 & 21.5 & 73.6 & 1.4 & 17500 & 62.9 \\
\hline
\end{tabular}


Table 6. Data from tile drains. T1 is the designation for the tile outside ELW.

\begin{tabular}{|c|c|c|c|c|c|c|c|c|c|c|c|c|c|c|}
\hline Location & Date & Q & $\mathrm{SpC}$ & $\mathrm{pH}$ & $\mathrm{F}^{-}$ & $\mathrm{Cl}^{-}$ & $\mathrm{Br}^{-}$ & $\mathrm{NO}_{3}-\mathrm{N}$ & $\mathrm{PO}_{4}-\mathrm{P}$ & $\mathrm{SO}_{4}{ }^{2-}$ & $\mathrm{Ca}^{2+}$ & $\mathrm{Mg}^{2+}$ & $\mathrm{Na}^{+}$ & $\mathrm{K}^{+}$ \\
\hline WS1 & $5 / 25 / 2018$ & 0.231 & 699.0 & 7.37 & 0.2 & 41.8 & $<0.05$ & 19.4 & 0.0 & 11.6 & 99.2 & 37.1 & 4.7 & 0.5 \\
\hline WS1 & $6 / 8 / 2018$ & 0.167 & 724.0 & 7.05 & 0.2 & 42.9 & $<0.05$ & 19.6 & 0.0 & 11.6 & 101 & 38.3 & 4.5 & 0.5 \\
\hline WS1 & $6 / 29 / 2018$ & 0.301 & 749.0 & 7.15 & 0.2 & 40.6 & $<0.05$ & 19.8 & 0.0 & 11.1 & 105 & 40.4 & 4.8 & 0.6 \\
\hline WS1 & $11 / 23 / 2018$ & 0.048 & 754.0 & 7.53 & 0.2 & 38.6 & $<0.05$ & 15.1 & 0.1 & 14.2 & 105 & 44.6 & 4.3 & 0.5 \\
\hline WS1 & $12 / 7 / 2018$ & 1.100 & 698.7 & 7.42 & 0.2 & 33.9 & $<0.05$ & 15.4 & 0.0 & 13.1 & 98.1 & 39.9 & 4.5 & 0.4 \\
\hline WS1 & $1 / 4 / 2019$ & 1.833 & 661.8 & 7.39 & 0.2 & 34.6 & $<0.05$ & 14.3 & 0.1 & 12.8 & 79.4 & 36.9 & 4.8 & 0.4 \\
\hline WS1 & $1 / 18 / 2018$ & 0.611 & 670.0 & 7.19 & 0.2 & 32.5 & $<0.05$ & 15.5 & 0.1 & 12.0 & 90.3 & 37.5 & 2.7 & 0.4 \\
\hline WS1 & $1 / 25 / 2019$ & - & 667.6 & 6.93 & 0.2 & 39.3 & $<0.05$ & 13.6 & 0.1 & 12.3 & 76.7 & 34.3 & 7.7 & 0.5 \\
\hline WS1 & 2/17/2019 & - & 640.0 & 7.61 & 0.2 & 38.6 & $<0.05$ & 13.5 & 0.1 & 12.4 & 74.9 & 32.5 & 5.4 & 0.6 \\
\hline WS1.25 & $11 / 2 / 2018$ & - & 706.0 & 7.96 & 0.2 & 25.9 & 0.05 & 6.4 & 0.0 & 9.8 & 99.4 & 37.9 & 6.8 & 1.5 \\
\hline WS1.25 & $12 / 14 / 2018$ & - & 684.5 & 7.03 & 0.2 & 29.8 & $<0.05$ & 8.7 & 0.0 & 10.9 & 103 & 37.5 & 3.4 & 1.3 \\
\hline WS1.25 & $12 / 14 / 2018$ & - & 1899 & 7.10 & 0.2 & 464 & $<0.05$ & 4.2 & 0.3 & 8.4 & 112 & 37.3 & 269 & 5.1 \\
\hline WS1.25 & $1 / 4 / 2019$ & - & 1191 & 7.36 & 0.2 & 167 & $<0.05$ & 7.9 & & 9.7 & 133 & 52.7 & 75.8 & 0.8 \\
\hline WS1.25 & $1 / 18 / 2018$ & - & 1880 & 7.81 & 0.2 & 409 & 0.09 & 9.3 & & 10.5 & 13 & 56.5 & 225 & 1.5 \\
\hline WS1.25 & 2/17/2019 & - & 1128 & 7.40 & 0.2 & 155 & 0.11 & 7.8 & 0.0 & 8.2 & 110 & 44.1 & 60.8 & 0.9 \\
\hline WS2 & $5 / 18 / 2018$ & 0.249 & 793.0 & 7.68 & 0.2 & 60.9 & $<0.05$ & 16.1 & 0.0 & 10.2 & 107 & 35.4 & 15.2 & 0.3 \\
\hline WS2 & $6 / 1 / 2018$ & 0.623 & 785.0 & 7.23 & 0.2 & 48.3 & $<0.05$ & 21.7 & & 10.0 & 109 & 38.3 & 14.0 & 1.4 \\
\hline WS2 & $6 / 15 / 2018$ & 0.857 & 830.0 & 6.89 & 0.2 & 57.7 & $<0.05$ & 19.7 & & 10.4 & 111 & 39 & 19.4 & 0.5 \\
\hline WS2 & $7 / 6 / 2018$ & 0.071 & 965.0 & 7.31 & 0.2 & 89.6 & $<0.05$ & 16.3 & & 11.8 & 123 & $3 ?$ & 24.8 & 0.4 \\
\hline WS2 & $11 / 30 / 2018$ & 0.200 & 892.0 & 7.47 & 0.2 & 76.5 & $<0.05$ & & & & & 45.1 & & 0.6 \\
\hline WS2 & 1/11/2019 & 0.458 & 860.0 & 6.88 & 0.2 & 67.7 & $<0.05$ & 15.0 & & 12.7 & 119 & 45.0 & 26.9 & 0.5 \\
\hline WS2 & 2/17/2019 & - & 843.0 & 7.95 & 0.2 & 73.2 & 0.0 & 12.5 & & 12.3 & 97.3 & 38.0 & 24.7 & 0.6 \\
\hline $\mathrm{T} 1$ & $2 / 21 / 2018$ & - & - & - & 0.2 & 93.6 & $<0.05$ & 3.5 & & 262 & 63.5 & 16.4 & 43.6 & 1.1 \\
\hline $\mathrm{T} 1$ & $2 / 21 / 2$ & - & - & - & 0.4 & 176 & $<0.05$ & 3. & & 440 & 0.0 & 50 & 31.1 & 7.0 \\
\hline $\mathrm{T} 1$ & $2 / 21 / 2018$ & - & - & - & 0.2 & 92.8 & $<0.05$ & 3.3 & & 466 & 55.2 & 1 & 39 & 0.8 \\
\hline $\mathrm{T} 1$ & $2 / 22 / 2018$ & - & - & - & 0.2 & 93.3 & $<0.05$ & 4.4 & & 403 & 86.1 & & 40 & 0.0 \\
\hline $\mathrm{T} 1$ & $2 / 23 / 2$ & - & - & - & 0.2 & 128 & $<0$ & 5. & & & 81.3 & & 53.5 & 0.0 \\
\hline $\mathrm{T} 1$ & $2 / 23 /$ & - & - & - & 0.2 & 117 & $<0$. & 5. & & & 82 & 27 & 47 & 0.0 \\
\hline $\mathrm{T} 1$ & $2 / 24 / 2018$ & - & - & - & 0.2 & 120 & $<0.05$ & 5.8 & & 435 & 83.2 & 31.3 & 49.8 & 0.0 \\
\hline $\mathrm{T} 1$ & $2 / 25 / 2018$ & - & - & - & 0.2 & 91.5 & $<0.05$ & 4.7 & & 450 & 80.9 & 24.6 & 41.3 & 0.0 \\
\hline $\mathrm{T} 1$ & $2 / 26$ & - & - & - & 0.2 & 80.9 & $<0$ & 4. & & & 82.7 & 2 & 37 & 0.0 \\
\hline $\mathrm{T} 1$ & $2 / 27 /$ & - & - & - & 0.2 & 57.3 & $<0.0$ & 3. & & 346 & 84.7 & 18.2 & 23.6 & 0.0 \\
\hline $\mathrm{T} 1$ & & - & - & - & 0.2 & 50.6 & $<0.0$ & 4.2 & & 72 & 75.7 & 17.0 & 16.4 & 0.0 \\
\hline $\mathrm{T} 1$ & 3 & - & - & - & 0.2 & 55.0 & $<0.0$ & 4.1 & & & 84.3 & 19.6 & 22.3 & 0.0 \\
\hline $\mathrm{T} 1$ & $4 / 2018$ & - & - & - & 0.2 & 49.8 & $<0.0$ & 3.6 & & & 84.9 & 17.9 & 22.1 & 0.0 \\
\hline $\mathrm{T} 1$ & & - & - & - & 0.2 & 33. & & 3 & & & 84.8 & & 9 & 0.0 \\
\hline $\mathrm{T}$ & $5 / 23$ & - & - & - & 0.2 & 20.7 & $<0$ & 5 & & 231 & 97.2 & & 5. & 1.0 \\
\hline $\mathrm{T} 1$ & $5 / 26 / 2018$ & - & - & - & 0.2 & 19.2 & $<0.05$ & 5.2 & & 221 & 101 & 19.3 & 4.2 & 0.8 \\
\hline $\mathrm{T} 1$ & $5 / 25 / 2018$ & - & - & - & 0.1 & 41.8 & $<0.05$ & 9.1 & & 12.0 & 36.8 & 34.8 & 15.3 & 0.6 \\
\hline $\mathrm{T} 1$ & $5 / 29$ & - & - & - & 0.1 & 39.9 & $<0$. & 10.0 & & 12.3 & 33.0 & 37 & 13.3 & 0.3 \\
\hline $\mathrm{T} 1$ & & - & - & - & 0.1 & 41.1 & & 9. & & 10 & 46.9 & & 13 & 0.7 \\
\hline $\mathrm{T} 1$ & & - & - & - & 0.2 & 20. & $<0$. & 4. & & 21 & 11 & 18.4 & 5.7 & 0.3 \\
\hline $\mathrm{T} 1$ & 4/2018 & - & - & - & 0.2 & 33.6 & $<0.05$ & 7.2 & 0. & 352 & 103 & 34.3 & 13.7 & 0.5 \\
\hline $\mathrm{T} 1$ & $6 / 2018$ & - & - & - & 0.3 & 39.6 & $<0.05$ & 9.8 & & 360 & 107 & 38.3 & 13.0 & 0.6 \\
\hline $\mathrm{T} 1$ & & - & - & - & 0.2 & 26.3 & & 5. & & & & 29 & 12.2 & 0.5 \\
\hline $\mathrm{T}$ & & - & - & - & 0.3 & 16.1 & & & & & 59 & 13.6 & 4. & 4.4 \\
\hline $\mathrm{T} 1$ & & - & - & - & 0.2 & 16.4 & $<0.0$ & 6. & & 223 & 52.0 & 8.8 & 4.9 & 3.4 \\
\hline $\mathrm{T} 1$ & $6 / 12 / 2018$ & - & - & - & 0.2 & 26.8 & $<0.05$ & 8.9 & & 461 & 73.6 & 17.5 & 10.9 & 3.7 \\
\hline $\mathrm{T} 1$ & 7/9/2018 & - & - & - & 0.2 & 22.8 & $<0.05$ & 3.5 & & 494 & 81.7 & 17.7 & 7.2 & 0.6 \\
\hline $\mathrm{T} 1$ & $7 / 15 / 2018$ & - & - & - & 0.2 & 32.9 & $<0.05$ & 2.3 & & 460 & 83.9 & 16.9 & 12.9 & 1.0 \\
\hline $\mathrm{T} 1$ & & - & - & - & 0.3 & 191 & & 2.0 & & 35 & 11 & 31.7 & 139 & 4.0 \\
\hline $\mathrm{T} 1$ & 9/8/2018 & - & - & - & 0.2 & 191 & $<0.0$ & 1.9 & & 553 & 118 & 32.0 & 160 & 2.1 \\
\hline $\mathrm{T} 1$ & $10 / 7 / 2018$ & - & - & - & 0.3 & 108 & $<0.05$ & 1.3 & 0.6 & 303 & 71.9 & 23.7 & 83.1 & 4.1 \\
\hline $\mathrm{T} 1$ & $10 / 8 / 2018$ & - & - & - & 0.3 & 50.8 & $<0.05$ & 2.6 & 2.4 & 304 & 84.4 & 21.5 & 38.9 & 5.2 \\
\hline
\end{tabular}


Table 6. Continued.

\begin{tabular}{|c|c|c|c|c|c|c|c|c|c|c|c|c|c|c|}
\hline Location & Date & Q & $\mathrm{SpC}$ & $\mathrm{pH}$ & $\mathrm{F}^{-}$ & $\mathrm{Cl}^{-}$ & $\mathrm{Br}^{-}$ & $\mathrm{NO}_{3}-\mathrm{N}$ & $\mathrm{PO}_{4}-\mathrm{P}$ & $\mathrm{SO}_{4}^{2-}$ & $\mathrm{Ca}^{2+}$ & $\mathrm{Mg}^{2+}$ & $\mathrm{Na}^{+}$ & $\mathrm{K}^{+}$ \\
\hline $\mathrm{T} 1$ & $10 / 8 / 2018$ & - & - & - & 0.5 & 62.0 & $<0.05$ & 1.9 & 6.2 & 306 & 117 & 31.3 & 51.5 & 13.8 \\
\hline $\mathrm{T} 1$ & $10 / 9 / 2018$ & - & - & - & 0.3 & 144 & $<0.05$ & 1.3 & 0.1 & 383 & 101 & 32.1 & 87.3 & 4.0 \\
\hline $\mathrm{T} 1$ & $10 / 14 / 2018$ & - & - & - & 0.3 & 63.2 & $<0.05$ & 0.9 & 0.1 & 274 & 85.1 & 26.6 & 53.6 & 3.1 \\
\hline $\mathrm{T} 1$ & $10 / 25 / 2018$ & - & - & - & 0.3 & 79.0 & $<0.05$ & 2.6 & 9.4 & 303 & 75.3 & 25.7 & 35.1 & 3.0 \\
\hline $\mathrm{T} 1$ & $10 / 31 / 2018$ & - & - & - & 0.2 & 85.3 & $<0.05$ & 3.2 & 1.0 & 467 & 82.8 & 24.0 & 57.5 & 14.8 \\
\hline T3 & $5 / 16 / 2018$ & - & - & - & 0.1 & 4.5 & 0.13 & 14.5 & 0.0 & 13.4 & 94.2 & 32.5 & 4.6 & 0.3 \\
\hline T3 & $6 / 28 / 2018$ & - & - & - & 0.2 & 5.2 & 0.15 & 15.7 & 0.0 & 13.8 & 76.6 & 30.0 & 3.7 & 0.3 \\
\hline T3 & $7 / 25 / 2018$ & - & - & - & 0.2 & 5.4 & 0.13 & 11.3 & 0.0 & 12.3 & 90.6 & 34.1 & 2.2 & 0.5 \\
\hline $\mathrm{T} 3$ & $8 / 24 / 2018$ & - & - & - & 0.2 & 5.4 & 0.11 & 11.6 & 0.0 & 12.7 & 90.2 & 36.9 & 6.0 & 0.5 \\
\hline $\mathrm{T} 3$ & $9 / 27 / 2018$ & - & - & - & 0.2 & 6.0 & 0.11 & 11.1 & 0.0 & 13.8 & 101 & 36.4 & 2.4 & 0.6 \\
\hline
\end{tabular}




\title{
APPENDIX B: EVENT SAMPLE MAJOR ION DATA
}

\author{
1. Dashes mean values are missing or were not measured \\ 2. All ion concentrations are in $\mathrm{mg} / \mathrm{l}$
}

Table 1. WS1 event sample data.

\begin{tabular}{|c|c|c|c|c|c|c|c|c|c|c|}
\hline Date & $\mathrm{F}^{-}$ & $\mathrm{Cl}^{-}$ & $\mathrm{Br}^{-}$ & $\mathrm{NO}_{3}-\mathrm{N}$ & $\mathrm{PO}_{4}-\mathrm{P}$ & $\mathrm{SO}_{4}{ }^{2-}$ & $\mathrm{Ca}^{2+}$ & $\mathrm{Mg}^{2+}$ & $\mathrm{Na}^{+}$ & $\mathrm{K}^{+}$ \\
\hline 2/19/2018 0:00 & 0.2 & 250 & 0.09 & 1.1 & 0.0 & 131 & 74.7 & 32.1 & 135 & 3.8 \\
\hline 2/19/2018 1:30 & 0.3 & 250 & 0.08 & 1.0 & 0.0 & 137 & 75.2 & 25.1 & 111 & 2.8 \\
\hline 2/19/2018 3:00 & 0.3 & 266 & 0.09 & 1.0 & 0.0 & 171 & 76.2 & 30.3 & 139 & 1.9 \\
\hline 2/19/2018 4:30 & 0.3 & 291 & 0.10 & 1.1 & 0.0 & 156 & 77.5 & 33.4 & 154 & 4.2 \\
\hline 2/19/2018 6:00 & 0.2 & 300 & 0.10 & 1.1 & 0.0 & 161 & 77.4 & 32.8 & 157 & 4.4 \\
\hline 2/19/2018 7:30 & 0.2 & 346 & 0.11 & 1.2 & 0.0 & 188 & 75.5 & 24.7 & 134 & 3.2 \\
\hline 2/19/2018 9:00 & 0.2 & 278 & 0.08 & 1.0 & 0.0 & 116 & 74.3 & 29.8 & 139 & 3.8 \\
\hline $2 / 19 / 2018$ 10:30 & 0.2 & 264 & 0.07 & 1.0 & 0.0 & 90.6 & 70.8 & 29.5 & 139 & 4.0 \\
\hline 2/19/2018 12:00 & 0.2 & 276 & 0.07 & 1.0 & 0.0 & 90.7 & 71.2 & 30.1 & 147 & 3.8 \\
\hline $2 / 20 / 2018$ 15:30 & 0.2 & 150 & $<0.05$ & 2.0 & 0.5 & 60.0 & 54.8 & 23.8 & 67.6 & 6.5 \\
\hline $2 / 20 / 2018$ 17:00 & 0.2 & 155 & $<0.05$ & 2.2 & 0.6 & 352 & 61.9 & 28.0 & 67.4 & 6.5 \\
\hline $2 / 20 / 2018$ 18:30 & 0.2 & 128 & $<0.05$ & 2.5 & 1.0 & 389 & 80.6 & 34.3 & 58.5 & 6.4 \\
\hline $2 / 20 / 201820: 00$ & 0.3 & 114 & $<0.05$ & 2.7 & 1.3 & 409 & 84.3 & 36.0 & 77.5 & 6.7 \\
\hline 2/20/2018 21:30 & 0.2 & 107 & $<0.05$ & 2.6 & 1.2 & 372 & 72.8 & 29.8 & 66.3 & 6.7 \\
\hline 2/20/2018 23:00 & 0.2 & 108 & $<0.05$ & 2.7 & 1.2 & 407 & 67.6 & 30.7 & 68.3 & 4.6 \\
\hline 2/21/2018 0:30 & 0.2 & 106 & $<0.05$ & 2.9 & 1.1 & 345 & 55.1 & 24.5 & 67.0 & 6.5 \\
\hline 2/21/2018 2:00 & 0.2 & 106 & $<0.05$ & 2.9 & 1.0 & 370 & 60.0 & 28.3 & 67.2 & 6.5 \\
\hline 2/21/2018 3:30 & 0.2 & 98.5 & $<0.05$ & 3.1 & 1.1 & 343 & 65.6 & 29.4 & 62.4 & 6.4 \\
\hline 2/21/2018 5:00 & 0.2 & 91.4 & $<0.05$ & 3.7 & 1.3 & 349 & 67.3 & 30.3 & 59.0 & 6.2 \\
\hline $2 / 21 / 20186: 30$ & 0.2 & 88.5 & $<0.05$ & 3.4 & 1.2 & 365 & 63.0 & 26.9 & 52.3 & 6.0 \\
\hline 2/21/2018 8:00 & 0.2 & 87.5 & $<0.05$ & 3.3 & 1.1 & 372 & 57.3 & 26.1 & 55.5 & 5.3 \\
\hline $2 / 21 / 20189: 30$ & 0.2 & 86.7 & $<0.05$ & 3.5 & 1.0 & 47.6 & 49.2 & 21.7 & 55.6 & 5.8 \\
\hline $2 / 21 / 2018$ 11:00 & 0.2 & 85.0 & $<0.05$ & 3.5 & 0.6 & 7.8 & 29.8 & 19.7 & 49.8 & 5.3 \\
\hline $2 / 21 / 2018$ 12:30 & 0.2 & 83.4 & $<0.05$ & 3.6 & 0.6 & 8.3 & 28.8 & 20.7 & 51.5 & 2.8 \\
\hline 2/21/2018 14:00 & 0.2 & 82.9 & $<0.05$ & 3.6 & 1.0 & 406 & 53.2 & 24.6 & 51.9 & 4.4 \\
\hline $2 / 21 / 2018$ 15:30 & 0.2 & 81.4 & $<0.05$ & 3.7 & 1.0 & 422 & 51.3 & 21.2 & 45.0 & 4.5 \\
\hline $2 / 21 / 2018$ 17:00 & 0.2 & 79.7 & $<0.05$ & 3.8 & 1.0 & 437 & 53.5 & 23.7 & 54.5 & 4.9 \\
\hline 2/22/2018 19:00 & 0.2 & 93.3 & $<0.05$ & 4.9 & 0.5 & 442 & 57.8 & 26.1 & 46.5 & 3.8 \\
\hline 2/22/2018 22:00 & 0.2 & 93.0 & $<0.05$ & 5.0 & 0.5 & 319 & 57.6 & 20.5 & 34.7 & 3.3 \\
\hline 2/23/2018 1:00 & 0.2 & 92.6 & 0.05 & 5.0 & 0.5 & 392 & 62.2 & 27.6 & 47.3 & 3.4 \\
\hline 2/23/2018 4:00 & 0.2 & 92.6 & $<0.05$ & 5.1 & 0.4 & 389 & 54.5 & 23.2 & 37.5 & 3.0 \\
\hline 2/23/2018 7:00 & 0.2 & 93.3 & $<0.05$ & 5.2 & 0.4 & 398 & 58.0 & 26.8 & 45.2 & 3.5 \\
\hline $2 / 23 / 2018$ 10:00 & 0.2 & 94.8 & $<0.05$ & 5.3 & 0.4 & 489 & 67.3 & 31.0 & 52.7 & 3.7 \\
\hline 2/23/2018 13:00 & 0.2 & 109 & $<0.05$ & 5.2 & 0.3 & 445 & 71.1 & 32.3 & 64.9 & 4.2 \\
\hline $2 / 23 / 2018$ 16:00 & 0.2 & 103 & $<0.05$ & 5.2 & 0.4 & 395 & 67.1 & 29.9 & 56.7 & 3.6 \\
\hline 2/23/2018 19:00 & 0.2 & 103 & $<0.05$ & 5.3 & 0.3 & 502 & 58.8 & 21.8 & 36.9 & 2.4 \\
\hline 2/23/2018 22:00 & 0.2 & 100 & $<0.05$ & 5.6 & 0.3 & 291 & 72.5 & 33.1 & 57.2 & 3.9 \\
\hline 2/24/2018 1:00 & 0.2 & 97.4 & $<0.05$ & 5.6 & 0.3 & 252 & 71.1 & 33.6 & 56.6 & 3.7 \\
\hline 2/24/2018 4:00 & 0.2 & 95.5 & $<0.05$ & 5.6 & 0.3 & 412 & 71.6 & 30.6 & 49.2 & 2.3 \\
\hline $2 / 24 / 2018$ 7:00 & 0.2 & 93.9 & $<0.05$ & 5.6 & 0.3 & 459 & 72.5 & 32.3 & 49.8 & 2.8 \\
\hline $2 / 24 / 2018$ 10:00 & 0.2 & 92.9 & $<0.05$ & 5.7 & 0.2 & 438 & 62.1 & 27.7 & 41.1 & 2.3 \\
\hline $2 / 24 / 2018$ 13:00 & 0.2 & 94.0 & $<0.05$ & 5.7 & 0.2 & 419 & 67.1 & 32.0 & 49.6 & 3.2 \\
\hline $2 / 24 / 2018$ 16:00 & 0.2 & 98.3 & $<0.05$ & 5.7 & 0.2 & 395 & 71.4 & 30.7 & 49.2 & 2.1 \\
\hline 2/24/2018 19:00 & 0.2 & 103 & $<0.05$ & 5.6 & 0.2 & 332 & 70.8 & 30.7 & 53.4 & 3.0 \\
\hline 2/24/2018 22:00 & 0.2 & 103 & $<0.05$ & 5.7 & 0.3 & 432 & 70.8 & 27.3 & 47.3 & 2.5 \\
\hline
\end{tabular}


Table 1. Continued.

\begin{tabular}{|c|c|c|c|c|c|c|c|c|c|c|}
\hline Date & $\mathrm{F}^{-}$ & $\mathrm{Cl}^{-}$ & $\mathrm{Br}^{-}$ & $\mathrm{NO}_{3}-\mathrm{N}$ & $\mathrm{PO}_{4}-\mathrm{P}$ & $\mathrm{SO}_{4}{ }^{2-}$ & $\mathrm{Ca}^{2+}$ & $\mathrm{Mg}^{2+}$ & $\mathrm{Na}^{+}$ & $\mathrm{K}^{+}$ \\
\hline $2 / 25 / 20181: 00$ & 0.2 & 105 & $<0.05$ & 5.7 & 0.2 & 374 & 73.8 & 33.2 & 62.3 & 3.3 \\
\hline $2 / 25 / 20184: 00$ & 0.2 & 104 & $<0.05$ & 5.8 & 0.4 & 372 & 70.2 & 18.8 & 34.0 & 1.9 \\
\hline $2 / 25 / 20187: 00$ & 0.2 & 95.9 & $<0.05$ & 5.7 & 0.3 & 388 & 68.8 & 31.3 & 56.8 & 3.3 \\
\hline 2/25/2018 10:00 & 0.2 & 96.8 & $<0.05$ & 5.9 & 0.3 & 448 & 70.9 & 32.2 & 56.7 & 3.2 \\
\hline 2/25/2018 13:00 & 0.2 & 93.8 & $<0.05$ & 6.0 & 0.2 & 451 & 71.9 & 31.4 & 52.4 & 3.0 \\
\hline 2/25/2018 14:10 & 0.2 & 92.7 & $<0.05$ & 5.8 & 0.2 & 933 & 70.1 & 32.2 & 52.4 & 2.9 \\
\hline $2 / 25 / 201822: 10$ & 0.2 & 89.9 & $<0.05$ & 6.2 & 0.2 & 507 & 74.4 & 26.9 & 38.5 & 2.1 \\
\hline $2 / 26 / 20186: 10$ & 0.2 & 90.0 & $<0.05$ & 6.2 & 0.2 & 474 & 76.6 & 35.7 & 49.9 & 3.1 \\
\hline 2/26/2018 22:10 & 0.2 & 89.0 & $<0.05$ & 6.2 & 0.1 & 590 & 77.9 & 28.1 & 35.5 & 2.0 \\
\hline 2/27/2018 14:10 & 0.2 & 89.1 & $<0.05$ & 6.3 & 0.0 & 408 & 80.1 & 35.5 & 45.5 & 2.3 \\
\hline $2 / 28 / 201822: 15$ & 0.2 & 86.9 & $<0.05$ & 6.4 & 0.1 & 466 & 82.9 & 35.3 & 42.2 & 2.1 \\
\hline $3 / 5 / 201821: 15$ & 0.2 & 72.3 & 0.05 & 7.2 & 0.0 & 431 & 76.2 & 21.7 & 21.5 & 1.2 \\
\hline $3 / 6 / 201820: 45$ & 0.2 & 79.9 & 0.06 & 6.9 & 0.0 & 431 & 74.3 & 29.4 & 34.9 & 1.7 \\
\hline $3 / 7 / 2018$ 23:00 & 0.2 & 84.4 & 0.06 & 6.6 & 0.0 & 422 & 65.3 & 30.8 & 36.7 & 1.7 \\
\hline $3 / 13 / 2018$ 15:30 & 0.2 & 74.8 & 0.05 & 6.6 & 0.0 & 379 & 82.2 & 26.0 & 24.9 & 1.2 \\
\hline 3/14/2018 11:00 & 0.2 & 74.0 & 0.05 & 6.7 & 0.0 & 369 & 79.5 & 31.7 & 29.7 & 1.3 \\
\hline 3/15/2018 13:15 & 0.2 & 71.7 & 0.07 & 7.0 & 0.0 & 435 & 78.5 & 19.6 & 16.8 & 0.7 \\
\hline $3 / 17 / 20184: 45$ & 0.2 & 76.7 & 0.05 & 5.9 & 0.0 & 433 & 74.1 & 20.7 & 22.7 & 1.1 \\
\hline $3 / 17 / 20187: 15$ & 0.2 & 74.2 & 0.07 & 6.4 & 0.0 & 428 & 76.1 & 24.2 & 23.8 & 1.1 \\
\hline 3/17/2018 10:15 & 0.2 & 105 & 0.06 & 4.5 & 0.1 & 418 & 63.0 & 17.4 & 36.5 & 1.3 \\
\hline $3 / 17 / 2018$ 14:30 & 0.2 & 101 & 0.05 & 4.9 & 0.0 & 436 & 67.8 & 26.3 & 49.2 & 2.0 \\
\hline $3 / 23 / 2018$ 15:15 & 0.2 & 57.1 & 0.05 & 4.8 & 0.0 & 360 & 74.3 & 23.0 & 20.7 & 0.8 \\
\hline $3 / 25 / 2018$ 14:30 & 0.2 & 205 & 0.07 & 3.9 & 0.0 & 320 & 68.3 & 20.6 & 69.6 & 1.2 \\
\hline 3/25/2018 19:15 & 0.2 & 199 & 0.06 & 4.2 & 0.0 & 342 & 71.3 & 28.5 & 78.1 & 1.7 \\
\hline $3 / 26 / 20183: 00$ & 0.1 & 131 & $<0.05$ & 2.1 & 0.0 & 223 & 47.4 & 15.3 & 52.6 & 0.9 \\
\hline $3 / 26 / 2018$ 12:30 & 0.1 & 141 & 0.05 & 3.0 & 0.0 & 305 & 72.2 & 17.3 & 59.4 & 1.0 \\
\hline $3 / 26 / 201820: 30$ & 0.1 & 97.1 & $<0.05$ & 2.5 & 0.0 & 250 & 68.4 & 19.3 & 53.9 & 1.0 \\
\hline $3 / 26 / 201822: 45$ & 0.2 & 147 & $<0.05$ & 3.8 & 0.1 & 349 & 72.2 & 26.1 & 78.6 & 1.7 \\
\hline 3/27/2018 0:45 & 0.1 & 152 & 0.07 & 4.3 & 0.1 & 302 & 75.9 & 22.9 & 56.9 & 1.4 \\
\hline $3 / 27 / 20183: 15$ & 0.2 & 104 & $<0.05$ & 5.9 & 0.8 & 429 & 71.8 & 24.8 & 51.2 & 1.3 \\
\hline $3 / 27 / 20184: 15$ & 0.4 & 99.7 & 0.05 & 7.2 & 2.1 & 374 & 118 & 44.0 & 58.4 & 2.8 \\
\hline $3 / 27 / 20184: 45$ & 0.4 & 81.7 & $<0.05$ & 6.3 & 1.8 & 421 & 147 & 41.8 & 45.2 & 2.9 \\
\hline $3 / 27 / 20185: 45$ & 0.3 & 70.5 & $<0.05$ & 5.9 & 2.6 & 418 & 98.6 & 33.3 & 43.1 & 3.6 \\
\hline $3 / 27 / 20187: 15$ & 0.3 & 43.9 & $<0.05$ & 4.5 & 1.9 & 321 & 95.2 & 28.5 & 22.4 & 2.7 \\
\hline $3 / 27 / 2018$ 7:45 & 0.5 & 68.0 & 0.05 & 6.8 & 2.2 & 332 & 138 & 57.5 & 40.8 & 5.7 \\
\hline $3 / 27 / 2018$ 12:30 & 0.5 & 64.1 & $<0.05$ & 6.4 & 4.8 & 1080 & 242 & 67.3 & 59.9 & 7.3 \\
\hline $3 / 27 / 2018$ 17:15 & 0.4 & 71.7 & 0.05 & 7.2 & 1.4 & 293 & 138 & 54.7 & 37.8 & 3.3 \\
\hline $3 / 27 / 2018$ 21:45 & 0.3 & 73.3 & 0.05 & 7.5 & 2.7 & 384 & 76.0 & 32.0 & 37.0 & 3.5 \\
\hline $3 / 28 / 2018$ 7:00 & 0.4 & 66.4 & $<0.05$ & 8.3 & 1.4 & 326 & 164 & 59.1 & 31.6 & 2.9 \\
\hline $3 / 28 / 2018$ 21:45 & 0.3 & 66.2 & 0.05 & 8.8 & 1.3 & 376 & 115 & 48.6 & 30.9 & 1.9 \\
\hline $3 / 30 / 20188: 45$ & 0.3 & 63.6 & $<0.05$ & 9.3 & 1.7 & 406 & 114 & 51.5 & 29.2 & 1.3 \\
\hline 3/30/2018 10:45 & 0.2 & 61.5 & 0.05 & 8.9 & 0.7 & 409 & 82.4 & 40.7 & 34.3 & 1.3 \\
\hline $3 / 31 / 2018$ 20:45 & 0.2 & 52.9 & 0.05 & 7.7 & 0.2 & 343 & 73.0 & 31.1 & 22.7 & 0.9 \\
\hline 4/3/2018 22:00 & 0.2 & 73.5 & $<0.05$ & 5.9 & 0.1 & 164 & 58.6 & 16.2 & 23.9 & 0.7 \\
\hline 4/4/2018 8:45 & 0.2 & 73.1 & 0.05 & 6.6 & 0.1 & 270 & 45.8 & 16.1 & 22.7 & 0.8 \\
\hline 4/10/2018 12:15 & 0.1 & 38.6 & 0.05 & 4.2 & 0.1 & 223 & 36.5 & 5.0 & 4.4 & 0.2 \\
\hline 4/13/2018 10:00 & 0.2 & 42.5 & $<0.05$ & 5.8 & 0.0 & 264 & 50.0 & 15.5 & 10.1 & 0.6 \\
\hline 4/14/2018 2:15 & 0.2 & 48.5 & $<0.05$ & 5.9 & 0.0 & 247 & 54.7 & 16.8 & 12.4 & 0.6 \\
\hline 4/14/2018 3:00 & 0.2 & 64.4 & $<0.05$ & 7.9 & 0.1 & 314 & 72.4 & 18.1 & 13.7 & 0.7 \\
\hline $4 / 14 / 20183: 15$ & 0.2 & 39.8 & $<0.05$ & 4.8 & 0.1 & 224 & 56.8 & 15.2 & 10.9 & 0.5 \\
\hline
\end{tabular}


Table 1. Continued.

\begin{tabular}{|c|c|c|c|c|c|c|c|c|c|c|}
\hline Date & $\mathrm{F}^{-}$ & $\mathrm{Cl}^{-}$ & $\mathrm{Br}^{-}$ & $\mathrm{NO}_{3}-\mathrm{N}$ & $\mathrm{PO}_{4}-\mathrm{P}$ & $\mathrm{SO}_{4}{ }^{2-}$ & $\mathrm{Ca}^{2+}$ & $\mathrm{Mg}^{2+}$ & $\mathrm{Na}^{+}$ & $\mathrm{K}^{+}$ \\
\hline 4/14/2018 5:00 & 0.2 & 52.6 & $<0.05$ & 4.0 & 0.2 & 209 & 59.6 & 12.1 & 18.3 & 0.8 \\
\hline 4/14/2018 6:00 & 0.2 & 66.8 & $<0.05$ & 4.9 & 0.1 & 259 & 60.5 & 16.7 & 28.7 & 1.3 \\
\hline 4/14/2018 7:30 & 0.2 & 89.1 & 0.05 & 6.7 & 0.3 & 314 & 69.9 & 21.8 & 35.8 & 2.0 \\
\hline 4/14/2018 8:00 & 0.2 & 88.2 & 0.05 & 5.2 & 0.4 & 324 & 65.5 & 20.2 & 44.6 & 2.3 \\
\hline 4/14/2018 9:30 & 0.2 & 69.7 & $<0.05$ & 5.1 & 0.3 & 342 & 58.7 & 15.2 & 28.7 & 1.6 \\
\hline 4/14/2018 10:45 & 0.2 & 74.5 & $<0.05$ & 6.6 & 0.1 & 385 & 60.5 & 18.2 & 32.1 & 1.8 \\
\hline $4 / 14 / 2018$ 12:45 & 0.2 & 79.1 & $<0.05$ & 7.4 & 0.1 & 406 & 61.2 & 18.1 & 27.2 & 1.1 \\
\hline 4/14/2018 17:00 & 0.2 & 91.5 & 0.06 & 8.2 & 0.0 & 353 & 66.8 & 19.1 & 31.8 & 1.3 \\
\hline $4 / 15 / 20183: 30$ & 0.2 & 81.0 & 0.06 & 8.5 & 0.1 & 398 & 68.8 & 26.9 & 38.0 & 1.9 \\
\hline $5 / 25 / 201812: 15$ & 0.2 & 34.0 & $<0.05$ & 4.6 & 0.1 & 307 & 75.1 & 27.1 & 12.5 & 0.8 \\
\hline $5 / 25 / 201816: 45$ & 0.2 & 42.3 & $<0.05$ & 6.1 & 0.2 & 358 & 75.0 & 29.9 & 14.6 & 1.1 \\
\hline 5/26/2018 0:15 & 0.2 & 29.3 & $<0.05$ & 4.1 & 0.1 & 235 & 62.7 & 21.0 & 10.0 & 0.7 \\
\hline $5 / 26 / 20186: 30$ & 0.2 & 37.8 & $<0.05$ & 6.0 & 0.0 & 286 & 74.2 & 29.4 & 14.8 & 0.5 \\
\hline $5 / 28 / 201813: 45$ & 0.2 & 49.4 & $<0.05$ & 6.0 & 0.1 & 355 & 76.0 & 25.9 & 14.0 & 1.1 \\
\hline $5 / 30 / 2018$ 13:45 & 0.1 & 25.3 & $<0.05$ & 3.0 & 0.2 & 1020 & 70.4 & 16.7 & 8.7 & 0.7 \\
\hline 5/30/2018 19:00 & 0.2 & 57.7 & $<0.05$ & 7.6 & 0.2 & 262 & 77.9 & 18.6 & 16.8 & 5.0 \\
\hline $5 / 30 / 2018$ 19:15 & 0.4 & 38.1 & $<0.05$ & 2.5 & 1.8 & 1600 & 74.4 & 19.6 & 16.6 & 4.2 \\
\hline $5 / 30 / 2018$ 19:30 & 0.3 & 36.2 & $<0.05$ & 4.7 & 1.7 & 1050 & 58.9 & 17.9 & 19.6 & 4.0 \\
\hline $5 / 30 / 201820: 30$ & 0.3 & 29.9 & $<0.05$ & 4.6 & 1.2 & 641 & 55.3 & 16.4 & 15.5 & 3.6 \\
\hline 5/30/2018 21:00 & 0.3 & 30.4 & $<0.05$ & 4.9 & 0.9 & 426 & 52.5 & 17.1 & 15.5 & 3.4 \\
\hline $5 / 30 / 201821: 30$ & 0.2 & 30.1 & $<0.05$ & 5.2 & 0.9 & 365 & - & - & - & - \\
\hline $5 / 31 / 2018$ 16:30 & - & - & - & - & - & - & 74.5 & 28.7 & 28.1 & 2.0 \\
\hline 6/1/2018 4:15 & 0.2 & 56.4 & $<0.05$ & 6.7 & 0.3 & 223 & 65.7 & 26.8 & 23.7 & 2.1 \\
\hline 6/1/2018 19:30 & 0.2 & 53.3 & $<0.05$ & 7.4 & 0.1 & 379 & 72.4 & 30.0 & 20.9 & 1.5 \\
\hline 6/2/2018 11:45 & 0.2 & 49.9 & $<0.05$ & 8.0 & 0.1 & 293 & 77.6 & 32.1 & 19.3 & 1.3 \\
\hline 6/8/2018 4:45 & 0.2 & 48.7 & $<0.05$ & 7.7 & 0.1 & 327 & 77.6 & 21.7 & 10.8 & 0.8 \\
\hline $6 / 10 / 20186: 45$ & 0.2 & 53.6 & $<0.05$ & 5.8 & 0.2 & 378 & 72.1 & 29.9 & 22.2 & 1.6 \\
\hline 6/10/2018 9:15 & 0.2 & 41.6 & $<0.05$ & 4.8 & 0.2 & 323 & 56.5 & 19.8 & 17.0 & 1.7 \\
\hline 6/10/2018 11:00 & 0.2 & 44.7 & $<0.05$ & 6.0 & 0.4 & 349 & 66.5 & 26.0 & 20.2 & 2.4 \\
\hline $6 / 10 / 2018$ 12:15 & 0.2 & 40.5 & $<0.05$ & 5.8 & 0.6 & 344 & 69.4 & 24.1 & 18.7 & 2.6 \\
\hline $6 / 10 / 2018$ 12:45 & 0.2 & 40.4 & $<0.05$ & 6.1 & 0.8 & 361 & 70.9 & 24.0 & 18.1 & 1.6 \\
\hline $6 / 10 / 2018$ 13:30 & 0.2 & 26.4 & $<0.05$ & 3.6 & 0.7 & 251 & 64.0 & 17.5 & 13.7 & 0.9 \\
\hline $6 / 10 / 2018$ 14:15 & 0.2 & 21.5 & $<0.05$ & 3.1 & 0.8 & 236 & 62.2 & 14.0 & 8.5 & 2.0 \\
\hline $6 / 10 / 2018$ 14:45 & 0.3 & 26.2 & $<0.05$ & 3.8 & 1.2 & 355 & 67.6 & 19.9 & 13.3 & 3.6 \\
\hline $6 / 10 / 2018$ 15:30 & 0.3 & 20.1 & $<0.05$ & 3.8 & 1.3 & 291 & 67.9 & 19.2 & 8.5 & 2.0 \\
\hline $6 / 10 / 2018$ 16:15 & 0.3 & 20.1 & $<0.05$ & 4.4 & 1.2 & 315 & 79.3 & 26.8 & 8.2 & 1.6 \\
\hline $6 / 10 / 2018$ 18:30 & 0.3 & 19.2 & $<0.05$ & 4.6 & 1.3 & 284 & 78.3 & 24.4 & 7.1 & 4.1 \\
\hline $6 / 10 / 201820: 30$ & 0.3 & 22.8 & $<0.05$ & 5.5 & 1.7 & 299 & 92.2 & 33.1 & 9.5 & 5.3 \\
\hline $6 / 10 / 201821: 45$ & 0.3 & 32.0 & $<0.05$ & 5.7 & 1.5 & 316 & 79.9 & 26.8 & 11.6 & 4.1 \\
\hline $6 / 10 / 201822: 45$ & 0.3 & 35.1 & $<0.05$ & 6.0 & 1.4 & 308 & 74.5 & 26.9 & 14.8 & 4.8 \\
\hline $6 / 11 / 2018$ 11:30 & 0.3 & 22.4 & $<0.05$ & 5.2 & 1.1 & 151 & 105 & 37.6 & 8.5 & 2.5 \\
\hline 6/11/2018 18:15 & 0.3 & 33.0 & $<0.05$ & 7.9 & 0.8 & 329 & 146 & 58.4 & 14.1 & 2.2 \\
\hline $6 / 12 / 20182: 30$ & 0.3 & 34.9 & $<0.05$ & 8.5 & 0.8 & 231 & 131 & 47.8 & 13.5 & 1.8 \\
\hline 6/19/2018 12:00 & 0.2 & 28.3 & $<0.05$ & 5.9 & 0.2 & 169 & 72.3 & 25.3 & 9.2 & 0.8 \\
\hline 6/21/2018 4:00 & 0.2 & 24.5 & $<0.05$ & 4.7 & 0.2 & 223 & 55.7 & 18.8 & 8.6 & 0.7 \\
\hline $6 / 21 / 2018$ 10:15 & 0.2 & 28.4 & $<0.05$ & 4.4 & 0.2 & 225 & 56.7 & 17.3 & 12.6 & 1.3 \\
\hline $6 / 21 / 2018$ 16:15 & 0.2 & 29.9 & $<0.05$ & 4.2 & 0.3 & 262 & 63.8 & 18.4 & 13.7 & 0.6 \\
\hline $6 / 21 / 2018$ 17:15 & 0.2 & 23.3 & $<0.05$ & 3.5 & 0.6 & 167 & 43.8 & 14.5 & 10.3 & 1.8 \\
\hline $6 / 21 / 201818: 15$ & 0.2 & 24.9 & $<0.05$ & 4.7 & 1.1 & 346 & 60.8 & 21.2 & 11.2 & 3.1 \\
\hline $6 / 21 / 2018$ 18:45 & 0.3 & 27.7 & $<0.05$ & 5.1 & 1.2 & 348 & 114 & 42.7 & 12.9 & 4.2 \\
\hline
\end{tabular}


Table 1. Continued.

\begin{tabular}{|c|c|c|c|c|c|c|c|c|c|c|}
\hline Date & $\mathrm{F}^{-}$ & $\mathrm{Cl}^{-}$ & $\mathrm{Br}^{-}$ & $\mathrm{NO}_{3}-\mathrm{N}$ & $\mathrm{PO}_{4}-\mathrm{P}$ & $\mathrm{SO}_{4}{ }^{2-}$ & $\mathrm{Ca}^{2+}$ & $\mathrm{Mg}^{2+}$ & $\mathrm{Na}^{+}$ & $\mathrm{K}^{+}$ \\
\hline $6 / 21 / 2018$ 19:00 & 0.3 & 21.0 & $<0.05$ & 3.8 & 1.4 & 181 & 91.0 & 29.1 & 8.2 & 4.0 \\
\hline $6 / 21 / 201820: 00$ & 0.3 & 15.6 & $<0.05$ & 2.7 & 1.3 & 304 & 64.3 & 21.7 & 5.6 & 4.1 \\
\hline $6 / 21 / 201823: 30$ & 0.3 & 17.4 & $<0.05$ & 3.1 & 1.4 & 309 & 49.7 & 16.5 & 6.0 & 1.6 \\
\hline 6/22/2018 0:45 & 0.3 & 18.0 & $<0.05$ & 3.5 & 1.3 & 302 & 51.0 & 15.5 & 5.3 & 2.9 \\
\hline $6 / 22 / 20183: 30$ & 0.3 & 24.5 & $<0.05$ & 4.0 & 1.4 & 273 & 72.0 & 23.5 & 10.9 & 4.3 \\
\hline $6 / 22 / 2018$ 8:30 & 0.3 & 33.5 & $<0.05$ & 5.1 & 1.0 & 340 & 71.8 & 28.7 & 16.1 & 4.6 \\
\hline $6 / 22 / 2018$ 13:15 & 0.3 & 35.3 & $<0.05$ & 5.9 & 0.8 & 363 & 88.6 & 31.4 & 13.1 & 3.5 \\
\hline $6 / 22 / 201822: 00$ & 0.3 & 35.8 & $<0.05$ & 6.3 & 0.8 & 342 & 80.7 & 31.0 & 14.8 & 2.2 \\
\hline $6 / 23 / 2018$ 23:00 & 0.2 & 40.6 & $<0.05$ & 8.3 & 0.3 & 315 & 65.9 & 14.2 & 7.7 & 0.8 \\
\hline 7/14/2018 9:00 & 0.2 & 37.2 & $<0.05$ & 4.3 & 0.2 & 388 & 74.6 & 32.2 & 13.0 & 1.6 \\
\hline $7 / 14 / 2018$ 10:45 & 0.2 & 36.5 & $<0.05$ & 4.3 & 0.2 & 347 & 73.9 & 33.2 & 13.7 & 1.4 \\
\hline 7/14/2018 11:00 & 0.2 & 38.1 & $<0.05$ & 4.3 & 0.2 & 364 & 74.3 & 33.1 & 14.4 & 1.4 \\
\hline $7 / 14 / 201820: 30$ & 0.2 & 48.2 & $<0.05$ & 4.2 & 0.2 & 383 & 68.0 & 27.7 & 20.2 & 3.2 \\
\hline $7 / 14 / 201822: 30$ & 0.2 & 48.2 & $<0.05$ & 2.8 & 0.3 & 353 & 49.9 & 18.0 & 22.5 & 4.3 \\
\hline 7/15/2018 0:45 & 0.2 & 44.2 & $<0.05$ & 1.8 & 0.3 & 348 & 42.5 & 14.9 & 21.7 & 3.5 \\
\hline 7/15/2018 4:45 & 0.2 & 45.4 & $<0.05$ & 2.8 & 0.2 & 356 & 58.0 & 22.2 & 21.3 & 1.7 \\
\hline 7/16/2018 8:30 & 0.2 & 55.6 & $<0.05$ & 2.8 & 0.1 & 377 & 70.1 & 30.3 & 24.9 & 2.3 \\
\hline 7/27/2018 4:30 & 0.2 & 47.4 & $<0.05$ & 1.4 & 0.1 & 373 & 54.3 & 11.4 & 4.6 & 0.5 \\
\hline $7 / 30 / 20188: 15$ & 0.2 & 44.2 & $<0.05$ & 1.1 & 0.0 & 371 & 71.0 & 35.9 & 18.7 & 1.6 \\
\hline 8/7/2018 3:00 & 0.2 & 32.7 & $<0.05$ & 1.0 & 0.0 & 378 & 56.4 & 23.8 & 8.5 & 1.3 \\
\hline $8 / 9 / 201820: 45$ & 0.2 & 39.5 & $<0.05$ & 0.8 & 0.1 & 424 & 59.3 & 24.4 & 10.4 & 1.4 \\
\hline 8/29/2018 7:30 & 0.3 & 34.1 & $<0.05$ & 0.6 & 0.3 & 286 & 46.4 & 23.6 & 16.5 & 3.2 \\
\hline $8 / 29 / 2018$ 16:45 & 0.2 & 60.4 & $<0.05$ & 0.7 & 0.2 & 238 & 43.1 & 18.8 & 29.5 & 5.4 \\
\hline 10/6/2018 8:00 & 0.1 & 36.0 & $<0.05$ & 0.6 & 0.4 & 272 & 27.0 & 8.2 & 16.7 & 3.6 \\
\hline 10/6/2018 12:00 & 0.1 & 44.3 & 0.07 & 0.7 & 0.5 & 269 & 25.4 & 8.4 & 18.1 & 4.1 \\
\hline $10 / 6 / 201814: 30$ & 0.1 & 27.6 & $<0.05$ & 0.5 & 0.3 & 141 & 24.0 & 6.6 & 13.5 & 2.6 \\
\hline 10/6/2018 17:00 & 0.1 & 40.0 & $<0.05$ & 0.7 & 0.3 & 223 & 24.2 & 6.6 & 13.1 & 4.5 \\
\hline 10/6/2018 19:15 & 0.1 & 48.6 & $<0.05$ & 0.7 & 0.4 & 274 & 31.9 & 10.2 & 28.6 & 4.4 \\
\hline 10/6/2018 20:30 & 0.1 & 35.4 & $<0.05$ & 0.6 & 0.3 & 163 & 24.8 & 7.3 & 21.5 & 2.9 \\
\hline $10 / 6 / 201822: 45$ & 0.2 & 76.8 & 0.10 & 0.7 & 0.3 & 257 & 49.5 & 18.6 & 44.2 & 5.0 \\
\hline 10/7/2018 0:15 & 0.2 & 51.8 & $<0.05$ & 0.7 & 0.4 & 237 & 45.7 & 15.4 & 31.4 & 4.1 \\
\hline $10 / 7 / 20184: 45$ & 0.1 & 33.8 & $<0.05$ & 0.7 & 0.6 & 304 & 30.0 & 8.6 & 18.9 & 4.1 \\
\hline 10/7/2018 8:00 & 0.1 & 42.3 & 0.05 & 0.7 & 0.4 & 259 & 36.7 & 12.1 & 26.3 & 4.6 \\
\hline $10 / 7 / 201812: 30$ & 0.2 & 48.6 & $<0.05$ & 0.6 & 0.2 & 243 & 42.0 & 12.0 & 24.9 & 2.9 \\
\hline 10/7/2018 18:30 & 0.2 & 60.1 & 0.07 & 0.6 & 0.1 & 271 & 44.0 & 15.1 & 29.8 & 2.9 \\
\hline 10/7/2018 20:30 & 0.2 & 55.5 & 0.06 & 0.7 & 0.3 & 266 & 41.2 & 14.5 & 27.7 & 2.9 \\
\hline 10/7/2018 21:00 & 0.3 & 57.8 & 0.08 & 0.7 & 0.6 & 302 & 55.8 & 15.3 & 22.1 & 3.7 \\
\hline $10 / 7 / 201822: 30$ & 0.3 & 32.1 & $<0.05$ & 0.6 & 0.7 & 268 & 48.0 & 15.3 & 19.8 & 4.2 \\
\hline 10/7/2018 23:00 & 0.2 & 42.4 & $<0.05$ & 0.6 & 0.9 & 239 & 53.4 & 17.7 & 25.0 & 4.8 \\
\hline 10/8/2018 1:00 & 0.2 & 46.0 & 0.06 & 0.8 & 0.8 & 230 & 60.1 & 19.0 & 24.4 & 4.9 \\
\hline $10 / 8 / 20181: 30$ & 0.2 & 34.1 & $<0.05$ & 0.8 & 1.0 & 242 & 56.0 & 19.0 & 20.5 & 5.0 \\
\hline $10 / 8 / 20182: 15$ & 0.2 & 24.7 & $<0.05$ & 0.7 & 1.0 & 263 & 40.2 & 9.3 & 9.7 & 3.1 \\
\hline $10 / 8 / 20183: 45$ & 0.2 & 24.9 & $<0.05$ & 0.8 & 0.8 & 258 & 49.8 & 10.3 & 10.6 & 3.6 \\
\hline 10/8/2018 5:00 & 0.2 & 28.9 & $<0.05$ & 0.9 & 0.8 & 226 & 38.4 & 9.7 & 13.3 & 4.0 \\
\hline 10/8/2018 8:30 & 0.2 & 42.3 & $<0.05$ & 1.2 & 0.6 & 252 & 41.9 & 14.5 & 24.3 & 4.9 \\
\hline 10/8/2018 12:00 & 0.2 & 48.3 & 0.06 & 1.2 & 0.4 & 283 & 39.5 & 16.0 & 28.4 & 4.4 \\
\hline $10 / 10 / 201823: 15$ & 0.2 & 45.0 & 0.05 & 1.0 & 0.4 & 246 & 42.1 & 13.2 & 20.8 & 3.6 \\
\hline 10/31/2018 4:00 & 0.2 & 44.5 & 0.06 & 0.7 & 0.6 & 224 & 44.9 & 11.3 & 17.9 & 2.9 \\
\hline 10/31/2018 7:00 & 0.2 & 62.0 & 0.08 & 1.1 & 0.7 & 253 & 50.1 & 13.6 & 21.3 & 3.2 \\
\hline $10 / 31 / 20187: 30$ & 0.1 & 32.3 & $<0.05$ & 0.8 & 0.5 & 164 & 40.6 & 6.8 & 10.5 & 1.6 \\
\hline
\end{tabular}


Table 1. Continued.

\begin{tabular}{|c|c|c|c|c|c|c|c|c|c|c|}
\hline Date & $\mathrm{F}^{-}$ & $\mathrm{Cl}^{-}$ & $\mathrm{Br}^{-}$ & $\mathrm{NO}_{3}-\mathrm{N}$ & $\mathrm{PO}_{4}-\mathrm{P}$ & $\mathrm{SO}_{4}{ }^{2-}$ & $\mathrm{Ca}^{2+}$ & $\mathrm{Mg}^{2+}$ & $\mathrm{Na}^{+}$ & $\mathrm{K}^{+}$ \\
\hline 10/31/2018 9:15 & 0.1 & 51.1 & 0.06 & 1.2 & 0.7 & 301 & 45.6 & 12.5 & 22.3 & 4.9 \\
\hline $10 / 31 / 2018$ 10:30 & 0.1 & 25.4 & $<0.05$ & 0.8 & 0.5 & 104 & 26.7 & 8.2 & 13.8 & 3.1 \\
\hline $10 / 31 / 201811: 45$ & 0.1 & 44.9 & $<0.05$ & 1.4 & 0.5 & 359 & 40.7 & 15.0 & 25.9 & 5.6 \\
\hline $10 / 31 / 2018 \quad 12: 45$ & 0.1 & 45.7 & $<0.05$ & 1.6 & 0.4 & 313 & 42.0 & 13.8 & 23.5 & 4.7 \\
\hline $11 / 25 / 201823: 45$ & 0.2 & 97.4 & $<0.05$ & 3.1 & 0.1 & 285 & 78.7 & 29.1 & 55.0 & 3.7 \\
\hline $11 / 26 / 20181: 45$ & 0.2 & 96.4 & $<0.05$ & 3.2 & 0.3 & 300 & 74.1 & 26.8 & 54.9 & 4.2 \\
\hline $11 / 26 / 20182: 45$ & 0.2 & 103 & $<0.05$ & 3.3 & 0.3 & 296 & 79.8 & 27.9 & 56.7 & 4.0 \\
\hline 11/26/2018 3:30 & 0.2 & 96.0 & $<0.05$ & 3.0 & 0.4 & 260 & 74.3 & 21.0 & 41.5 & 3.2 \\
\hline $11 / 26 / 20185: 15$ & 0.2 & 87.8 & $<0.05$ & 3.1 & 0.3 & 280 & 67.4 & 23.7 & 51.5 & 4.1 \\
\hline 11/26/2018 7:15 & 0.2 & 77.8 & $<0.05$ & 3.3 & 0.4 & 249 & 59.6 & 21.1 & 45.1 & 4.5 \\
\hline $11 / 26 / 20188: 45$ & 0.2 & 74.6 & $<0.05$ & 3.6 & 0.2 & 305 & 60.4 & 12.6 & 24.4 & 2.2 \\
\hline $11 / 26 / 201811: 45$ & 0.2 & 75.0 & $<0.05$ & 4.1 & 0.1 & 338 & 63.9 & 23.3 & 40.5 & 3.7 \\
\hline $11 / 26 / 2018 \quad 16: 30$ & 0.2 & 86.8 & $<0.05$ & 4.4 & 0.1 & 332 & 69.4 & 25.9 & 49.8 & 3.5 \\
\hline 12/1/2018 10:15 & 0.2 & 118 & $<0.05$ & 4.0 & 0.2 & 257 & 78.9 & 26.1 & 65.5 & 4.0 \\
\hline $12 / 1 / 2018$ 10:45 & 0.2 & 104 & $<0.05$ & 4.0 & 0.4 & 333 & 70.7 & 24.7 & 55.3 & 3.7 \\
\hline 12/1/2018 11:30 & 0.2 & 107 & $<0.05$ & 4.2 & 0.6 & 299 & 82.8 & 25.8 & 55.1 & 4.0 \\
\hline $12 / 1 / 2018$ 13:00 & 0.2 & 106 & $<0.05$ & 4.4 & 0.7 & 247 & 92.5 & 30.1 & 59.4 & 4.9 \\
\hline $12 / 1 / 201813: 30$ & 0.2 & 126 & $<0.05$ & 3.9 & 1.1 & 206 & 94.8 & 28.6 & 73.7 & 5.4 \\
\hline $12 / 1 / 201814: 30$ & 0.2 & 92.9 & $<0.05$ & 3.4 & 1.3 & 283 & 86.0 & 27.8 & 54.0 & 5.9 \\
\hline $12 / 1 / 201815: 15$ & 0.2 & 72.0 & $<0.05$ & 3.2 & 0.8 & 251 & 68.4 & 19.2 & 35.7 & 4.5 \\
\hline 12/1/2018 16:00 & 0.2 & 68.1 & $<0.05$ & 3.9 & 0.9 & 319 & 70.4 & 22.2 & 33.3 & 4.3 \\
\hline 12/1/2018 16:30 & 0.2 & 65.7 & $<0.05$ & 4.3 & 0.8 & 246 & 89.1 & 26.8 & 36.6 & 5.2 \\
\hline $12 / 1 / 201818: 30$ & 0.2 & 57.8 & $<0.05$ & 5.1 & 0.6 & 264 & 63.0 & 22.3 & 29.3 & 3.8 \\
\hline $12 / 1 / 201821: 45$ & 0.2 & 58.1 & $<0.05$ & 4.7 & 0.7 & 454 & 81.1 & 26.0 & 30.9 & 3.5 \\
\hline 12/2/2018 8:15 & 0.2 & 69.4 & $<0.05$ & 5.6 & 0.8 & 345 & 87.0 & 29.5 & 37.5 & 3.9 \\
\hline $12 / 2 / 201813: 30$ & 0.2 & 65.6 & $<0.05$ & 5.4 & 0.4 & 343 & 77.0 & 26.4 & 33.4 & 3.1 \\
\hline 12/3/2018 7:30 & 0.2 & 68.9 & $<0.05$ & 6.0 & 0.2 & 252 & 83.7 & 30.6 & 35.9 & 2.9 \\
\hline 12/13/2018 13:00 & 0.2 & 62.8 & $<0.05$ & 6.3 & 0.3 & 364 & 99.6 & 37.1 & 29.1 & 1.5 \\
\hline $12 / 13 / 201821: 30$ & 0.2 & 60.9 & $<0.05$ & 6.5 & 0.0 & 324 & 97.4 & 30.8 & 23.8 & 1.2 \\
\hline $12 / 13 / 201823: 30$ & 0.2 & 59.5 & $<0.05$ & 6.2 & 0.0 & 372 & 95.8 & 26.6 & 20.6 & 1.0 \\
\hline $12 / 14 / 2018 \quad 16: 45$ & 0.2 & 129 & $<0.05$ & 6.2 & 0.0 & 293 & 92.5 & 27.5 & 53.6 & 2.0 \\
\hline $12 / 14 / 2018$ 18:45 & 0.2 & 104 & $<0.05$ & 5.3 & 0.1 & 303 & 89.1 & 26.8 & 50.4 & 1.9 \\
\hline $12 / 14 / 201822: 30$ & 0.2 & 108 & $<0.05$ & 5.9 & 0.0 & 245 & 91.1 & 33.6 & 60.6 & 2.4 \\
\hline $12 / 27 / 2018 \quad 12: 45$ & 0.2 & 78.1 & $<0.05$ & 5.8 & 0.1 & 299 & 98.5 & 34.9 & 40.8 & 2.6 \\
\hline $12 / 27 / 2018$ 14:00 & 0.2 & 70.7 & $<0.05$ & 5.4 & 0.1 & 264 & 85.9 & 23.9 & 29.4 & 1.7 \\
\hline $12 / 27 / 2018 \quad 14: 45$ & 0.2 & 68.2 & $<0.05$ & 5.0 & 0.2 & 243 & 80.3 & 22.4 & 27.8 & 1.8 \\
\hline $12 / 27 / 201816: 30$ & 0.2 & 79.6 & $<0.05$ & 6.1 & 0.5 & 267 & 89.9 & 26.2 & 33.5 & 1.9 \\
\hline $12 / 27 / 201818: 15$ & 0.2 & 69.4 & $<0.05$ & 5.9 & 0.3 & 272 & 77.9 & 21.5 & 27.9 & 1.7 \\
\hline $12 / 27 / 201819: 30$ & 0.2 & 69.6 & $<0.05$ & 5.8 & 0.3 & 279 & 75.2 & 20.3 & 26.6 & 1.7 \\
\hline $12 / 27 / 201821: 15$ & 0.2 & 59.9 & $<0.05$ & 6.1 & 0.1 & 278 & 74.4 & 17.4 & 18.5 & 1.2 \\
\hline $12 / 28 / 20181: 45$ & 0.2 & 61.4 & $<0.05$ & 7.6 & 0.1 & 281 & 83.8 & 23.0 & 20.8 & 1.4 \\
\hline 12/28/2018 9:30 & 0.2 & 62.3 & $<0.05$ & 7.4 & 0.2 & 291 & 103 & 38.2 & 35.4 & 2.1 \\
\hline $12 / 28 / 201812: 15$ & 0.2 & 66.2 & $<0.05$ & 7.5 & 0.1 & 354 & 86.1 & 33.6 & 32.5 & 2.1 \\
\hline $12 / 31 / 201812: 15$ & 0.2 & 61.7 & $<0.05$ & 6.1 & 0.1 & 257 & 70.6 & 22.8 & 23.0 & 1.3 \\
\hline $12 / 31 / 201813: 00$ & 0.2 & 63.4 & $<0.05$ & 6.5 & 0.1 & 255 & 56.2 & 18.8 & 17.7 & 1.1 \\
\hline $12 / 31 / 201813: 30$ & 0.2 & 65.4 & $<0.05$ & 6.2 & 0.3 & 311 & 75.4 & 19.9 & 23.7 & 1.7 \\
\hline $12 / 31 / 201814: 30$ & 0.2 & 57.0 & $<0.05$ & 5.6 & 0.4 & 267 & 52.2 & 17.3 & 18.1 & 1.6 \\
\hline $12 / 31 / 201815: 15$ & 0.2 & 54.6 & $<0.05$ & 5.3 & 0.7 & 302 & 78.3 & 21.4 & 19.8 & 2.5 \\
\hline $12 / 31 / 201816: 15$ & 0.2 & 44.6 & $<0.05$ & 5.3 & 0.9 & 281 & 99.0 & 26.3 & 19.8 & 3.6 \\
\hline $12 / 31 / 201816: 45$ & 0.2 & 41.6 & $<0.05$ & 4.8 & 1.3 & 256 & 104 & 30.5 & 21.8 & 4.9 \\
\hline
\end{tabular}


Table 1. Continued.

\begin{tabular}{|c|c|c|c|c|c|c|c|c|c|c|}
\hline Date & $\mathrm{F}^{-}$ & $\mathrm{Cl}^{-}$ & $\mathrm{Br}^{-}$ & $\mathrm{NO}_{3}-\mathrm{N}$ & $\mathrm{PO}_{4}-\mathrm{P}$ & $\mathrm{SO}_{4}{ }^{2-}$ & $\mathrm{Ca}^{2+}$ & $\mathrm{Mg}^{2+}$ & $\mathrm{Na}^{+}$ & $\mathrm{K}^{+}$ \\
\hline 12/31/2018 18:00 & 0.2 & 33.3 & $<0.05$ & 4.4 & 1.5 & 267 & 95.5 & 26.3 & 12.4 & 6.8 \\
\hline $12 / 31 / 201818: 45$ & 0.2 & 31.5 & $<0.05$ & 4.6 & 1.4 & 243 & 121 & 34.3 & 15.1 & 6.5 \\
\hline $12 / 31 / 2018$ 19:45 & 0.2 & 31.6 & $<0.05$ & 4.9 & 1.4 & 295 & 41.5 & 16.2 & 7.7 & 6.3 \\
\hline $12 / 31 / 201821: 30$ & 0.3 & 39.3 & $<0.05$ & 6.2 & 1.3 & 335 & 93.9 & 33.4 & 18.3 & 5.2 \\
\hline 1/1/2019 1:00 & 0.2 & 46.4 & $<0.05$ & 6.9 & 0.8 & 253 & 71.8 & 27.4 & 22.3 & 4.1 \\
\hline 1/1/2019 5:00 & 0.2 & 44.1 & $<0.05$ & 6.4 & 0.7 & 236 & 101 & 35.2 & 22.2 & 3.3 \\
\hline 1/1/2019 12:00 & 0.3 & 47.1 & $<0.05$ & 6.9 & 0.5 & 252 & 83.0 & 30.6 & 22.2 & 3.4 \\
\hline 1/2/2019 0:15 & 0.5 & 50.4 & $<0.05$ & 7.9 & 0.5 & 265 & 93.3 & 32.9 & 24.3 & 3.5 \\
\hline 1/2/2019 7:00 & 0.3 & 49.4 & $<0.05$ & 8.0 & 1.0 & 276 & 94.2 & 33.7 & 23.7 & 3.0 \\
\hline $1 / 2 / 201917: 30$ & 0.4 & 51.1 & $<0.05$ & 8.7 & 1.4 & 287 & 131 & 40.6 & 19.8 & 2.2 \\
\hline $2 / 6 / 201914: 25$ & 0.3 & 66.8 & $<0.05$ & 6.6 & 1.0 & 291 & 98.6 & 39.0 & 30.8 & 3.5 \\
\hline $2 / 6 / 201918: 30$ & 0.2 & 54.7 & 0.06 & 6.5 & 0.8 & 264 & 75.7 & 26.5 & 21.2 & 2.8 \\
\hline $2 / 7 / 20196: 30$ & 0.3 & 35.4 & $<0.05$ & 4.8 & 2.0 & 271 & 118 & 32.2 & 14.6 & 7.1 \\
\hline $2 / 7 / 201914: 25$ & 0.2 & 45.0 & 0.05 & 5.3 & 1.2 & 229 & 59.8 & 20.1 & 17.6 & 4.0 \\
\hline $2 / 7 / 2019$ 16:25 & 0.2 & 46.7 & $<0.05$ & 5.8 & 1.0 & 237 & 64.7 & 24.5 & 20.7 & 3.7 \\
\hline 2/11/2019 10:40 & 0.2 & 91.5 & $<0.05$ & 5.5 & 0.6 & 218 & 75.6 & 27.0 & 47.5 & 3.0 \\
\hline 2/12/2019 8:40 & 0.3 & 88.5 & $<0.05$ & 5.0 & 1.3 & 338 & 84.3 & 28.5 & 45.0 & 2.9 \\
\hline $2 / 12 / 201912: 35$ & 0.2 & 112 & $<0.05$ & 5.5 & 0.5 & 286 & 79.0 & 28.9 & 59.2 & 3.0 \\
\hline 2/12/2019 14:40 & 0.2 & 137 & 0.06 & 5.7 & 0.7 & 276 & 76.2 & 28.9 & 73.8 & 3.1 \\
\hline $2 / 12 / 2019$ 16:40 & 0.2 & 156 & $<0.05$ & 5.9 & 0.7 & 270 & 69.2 & 19.9 & 60.2 & 2.2 \\
\hline
\end{tabular}

Table 2. WS1.25 event data.

\begin{tabular}{|c|c|c|c|c|c|c|c|c|c|c|}
\hline Date & $\mathrm{F}^{-}$ & $\mathrm{Cl}^{-}$ & $\mathrm{Br}^{-}$ & $\mathrm{NO}_{3}-\mathrm{N}$ & $\mathrm{PO}_{4}-\mathrm{P}$ & $\mathrm{SO}_{4}{ }^{2-}$ & $\mathrm{Ca}^{2+}$ & $\mathrm{Mg}^{2+}$ & $\mathrm{Na}^{+}$ & $\mathrm{K}^{+}$ \\
\hline 9/7/2018 9:00 & 0.3 & 68.9 & 0.05 & 0.4 & 0.0 & 14.1 & 68.4 & 29.5 & 36.9 & 4.6 \\
\hline 9/7/2018 11:30 & 0.4 & 69.0 & $<0.05$ & 0.4 & 0.0 & 14.1 & 68.6 & 26.8 & 36.5 & 2.9 \\
\hline 9/7/2018 14:00 & 0.3 & 75.9 & $<0.05$ & 0.4 & 0.0 & 15.0 & 67.2 & 26.3 & 41.0 & 4.9 \\
\hline 9/7/2018 16:30 & 0.3 & 78.1 & 0.06 & 0.4 & 0.0 & 11.7 & 61.0 & 22.9 & 41.2 & 4.9 \\
\hline 9/7/2018 19:00 & 0.3 & 82.4 & 0.14 & 0.4 & 0.0 & 11.5 & 60.4 & 20.8 & 43.8 & 5.8 \\
\hline 9/7/2018 21:30 & 0.3 & 80.0 & 0.14 & 0.4 & 0.0 & 11.3 & 53.4 & 17.6 & 44.2 & 2.8 \\
\hline 9/8/2018 0:00 & 0.2 & 79.5 & 0.10 & 0.5 & 0.0 & 10.3 & 50.4 & 15.6 & 46.3 & 4.0 \\
\hline $9 / 8 / 20182: 30$ & 0.2 & 73.7 & 0.08 & 0.7 & 0.0 & 9.1 & 44.0 & 12.9 & 44.1 & 4.5 \\
\hline 9/8/2018 5:00 & 0.2 & 58.8 & $<0.05$ & 0.7 & 0.0 & 7.3 & 17.6 & 9.5 & 36.6 & 3.9 \\
\hline 9/8/2018 10:00 & 0.2 & 46.1 & $<0.05$ & 0.7 & 0.1 & 6.7 & 34.4 & 7.6 & 30.4 & 3.2 \\
\hline 9/8/2018 15:00 & 0.2 & 55.0 & $<0.05$ & 0.7 & 0.1 & 7.4 & 39.9 & 9.9 & 36.0 & 2.0 \\
\hline 9/8/2018 20:00 & 0.2 & 65.9 & $<0.05$ & 0.6 & 0.0 & 7.3 & 45.3 & 14.5 & 39.8 & 3.3 \\
\hline 9/9/2018 3:30 & 0.2 & 53.6 & $<0.05$ & 0.6 & 0.1 & 6.1 & 47.5 & 14.5 & 31.2 & 3.2 \\
\hline 9/9/2018 10:45 & 0.2 & 65.1 & $<0.05$ & 0.6 & 0.0 & 7.7 & 47.1 & 17.6 & 36.6 & 1.9 \\
\hline
\end{tabular}


Table 3. WS1.5 event data.

\begin{tabular}{|c|c|c|c|c|c|c|c|c|c|c|}
\hline Date & $\mathrm{F}^{-}$ & $\mathrm{Cl}^{-}$ & $\mathrm{Br}^{-}$ & $\mathrm{NO}_{3}-\mathrm{N}$ & $\mathrm{PO}_{4}-\mathrm{P}$ & $\mathrm{SO}_{4}{ }^{-2}$ & $\mathrm{Ca}^{2+}$ & $\mathrm{Mg}^{2+}$ & $\mathrm{Na}^{+}$ & $\mathrm{K}^{+}$ \\
\hline 2/19/2018 17:30 & 0.2 & 186 & 0.08 & 1.1 & 0.0 & 10.0 & 59.0 & 21.5 & 113 & 4.2 \\
\hline 2/19/2018 19:00 & 0.1 & 142 & $<0.05$ & 1.0 & 0.0 & 7.1 & 43.4 & 15.0 & 87.9 & 3.8 \\
\hline 2/19/2018 20:15 & 0.2 & 140 & 0.07 & 1.1 & 0.0 & 7.4 & 47.6 & 14.3 & 70.0 & 3.0 \\
\hline 2/19/2018 21:45 & 0.1 & 166 & 0.07 & 1.4 & 0.0 & 8.8 & 55.4 & 18.2 & 100 & 4.9 \\
\hline 2/19/2018 23:15 & 0.1 & 139 & $<0.05$ & 1.3 & 0.0 & 8.0 & 49.6 & 15.8 & 72.2 & 3.6 \\
\hline 2/20/2018 0:45 & 0.1 & 162 & 0.07 & 1.5 & 0.0 & 9.1 & 52.6 & 18.2 & 88.8 & 4.9 \\
\hline $2 / 20 / 20182: 15$ & 0.1 & 128 & $<0.05$ & 1.4 & 0.1 & 7.8 & 46.3 & 13.8 & 66.3 & 3.9 \\
\hline 2/20/2018 3:45 & 0.1 & 140 & 0.06 & 1.6 & 0.1 & 8.5 & 48.3 & 15.8 & 73.2 & 3.8 \\
\hline $2 / 20 / 20185: 15$ & 0.1 & 141 & 0.06 & 1.7 & 0.2 & 8.4 & 52.3 & 18.7 & 82.9 & 6.1 \\
\hline $2 / 20 / 20186: 45$ & 0.1 & 135 & 0.06 & 1.8 & 0.1 & 8.5 & 50.6 & 17.7 & 77.8 & 6.0 \\
\hline $3 / 26 / 2018$ 16:00 & 0.1 & 160 & 0.07 & 4.5 & 0.0 & 12.2 & 95.7 & 28.9 & 81.0 & 1.7 \\
\hline $3 / 26 / 201818: 30$ & 0.1 & 268 & 0.09 & 3.5 & 0.0 & 10.8 & 88.6 & 19.2 & 108 & 1.1 \\
\hline $3 / 26 / 2018$ 21:00 & 0.1 & 134 & $<0.05$ & 3.2 & 0.0 & 7.6 & 61.2 & 14.9 & 60.9 & 1.0 \\
\hline $3 / 26 / 2018$ 23:30 & 0.1 & 126 & 0.05 & 5.7 & 0.0 & 8.1 & 65.6 & 21.9 & 73.4 & 1.1 \\
\hline 3/27/2018 2:00 & 0.1 & 78.7 & $<0.05$ & 5.8 & 0.0 & 5.9 & 44.6 & 15.8 & 45.0 & 1.4 \\
\hline $3 / 27 / 20184: 30$ & 0.2 & 93.5 & $<0.05$ & 5.9 & 0.6 & 6.9 & 52.4 & 16.8 & 46.8 & 2.1 \\
\hline $3 / 27 / 2018$ 7:00 & 0.2 & 94.6 & $<0.05$ & 6.2 & 0.6 & 7.8 & 61.0 & 19.7 & 57.7 & 3.5 \\
\hline $3 / 27 / 20189: 30$ & 0.2 & 89.4 & $<0.05$ & 6.1 & 1.1 & 7.3 & 50.6 & 18.5 & 47.8 & 2.4 \\
\hline $3 / 27 / 2018$ 12:00 & 0.2 & 85.5 & $<0.05$ & 5.8 & 1.3 & 7.4 & 55.8 & 19.0 & 46.2 & 2.2 \\
\hline $3 / 27 / 2018$ 17:00 & 0.2 & 91.4 & $<0.05$ & 6.0 & 1.0 & 8.3 & 60.7 & 20.2 & 46.0 & 3.6 \\
\hline $3 / 27 / 2018$ 22:00 & 0.2 & 84.2 & $<0.05$ & 6.5 & 0.7 & 8.3 & 63.3 & 21.0 & 44.8 & 3.2 \\
\hline 3/28/2018 5:30 & 0.2 & 71.9 & $<0.05$ & 7.2 & 0.7 & 8.4 & 66.3 & 20.5 & 34.9 & 1.3 \\
\hline $3 / 28 / 2018$ 15:30 & 0.2 & 76.1 & $<0.05$ & 7.8 & 0.3 & 8.9 & 67.4 & 24.7 & 38.5 & 1.2 \\
\hline $3 / 29 / 2018$ 1:30 & 0.2 & 71.7 & $<0.05$ & 8.0 & 0.2 & 9.0 & 84.0 & 25.8 & 35.9 & 1.9 \\
\hline $3 / 29 / 2018$ 12:00 & 0.2 & 73.1 & $<0.05$ & 8.0 & 0.2 & 9.8 & 80.8 & 24.4 & 33.6 & 1.1 \\
\hline $3 / 29 / 2018$ 20:00 & 0.2 & 67.0 & $<0.05$ & 7.4 & 0.2 & 9.1 & 68.1 & 23.6 & 31.0 & 1.4 \\
\hline 3/30/2018 14:00 & 0.2 & 71.8 & $<0.05$ & 8.4 & 0.1 & 10.1 & 72.0 & 24.9 & 28.9 & 1.4 \\
\hline 3/30/2018 22:00 & 0.2 & 67.9 & $<0.05$ & 7.7 & 0.0 & 9.6 & 63.9 & 10.7 & 15.7 & 0.5 \\
\hline 5/3/2018 1:00 & 0.2 & 61.9 & $<0.05$ & 7.6 & 0.0 & 12.4 & 55.6 & 19.2 & 13.7 & 0.3 \\
\hline 5/3/2018 3:30 & 0.2 & 59.0 & $<0.05$ & 6.8 & 0.0 & 11.2 & 84.6 & 16.5 & 11.1 & 0.3 \\
\hline 5/3/2018 6:00 & 0.1 & 67.2 & 0.07 & 7.7 & 0.0 & 12.1 & 91.9 & 35.0 & 30.6 & 1.3 \\
\hline 5/3/2018 8:30 & 0.2 & 78.8 & $<0.05$ & 6.1 & 0.0 & 12.0 & 94.0 & 31.4 & 33.8 & 1.3 \\
\hline 5/3/2018 11:00 & 0.2 & 77.1 & 0.06 & 6.5 & 0.0 & 12.0 & 104 & 33.1 & 36.2 & 1.4 \\
\hline 5/3/2018 13:30 & 0.1 & 75.5 & 0.06 & 6.2 & 0.0 & 11.4 & 84.0 & 16.3 & 15.8 & 0.6 \\
\hline 5/3/2018 16:00 & 0.1 & 74.3 & $<0.05$ & 6.0 & 0.0 & 11.6 & 92.4 & 31.4 & 35.9 & 1.5 \\
\hline
\end{tabular}

